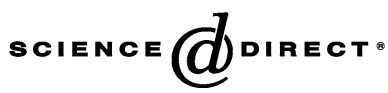

Ore Geology Reviews xx (2005) xxx-xxx
ORE GEOLOGY REVIEWS

ELSEVIER

www.elsevier.com/locate/oregeorev

\title{
Precambrian geodynamics and ore formation: The Fennoscandian Shield
}

\author{
Pär Weihed ${ }^{\mathrm{a}, *}$, Nicholas Arndt ${ }^{\mathrm{b}}$, Kjell Billström ${ }^{\mathrm{c}}$, Jean-Clair Duchesne ${ }^{\mathrm{d}}$, Pasi Eilu ${ }^{\mathrm{e}}$, \\ Olof Martinsson $^{\text {a }}$, Heikki Papunen ${ }^{\mathrm{f}}$, Raimo Lahtinen ${ }^{\mathrm{e}}$ \\ ${ }^{a}$ Division of Ore Geology and Applied Geophysics, Luleå University of Technology, SE-971 87 Luleå, Sweden \\ ${ }^{\mathrm{b}}$ LGCA, Université Joseph Fourier, Grenoble, Maison des Géosciences 1381, rue de la Piscine 38400 Saint Martin d'Heres, France \\ ' Swedish Museum of Natural History, Stockholm, Box 50007, SE-10405, Sweden \\ ${ }^{\mathrm{d}}$ University of Liège Bat. B20, B-4000 Sart Tilman, Belgium \\ e Geological Survey of Finland, PO Box 96, FIN-02151 Espoo, Finland \\ ${ }^{\mathrm{f}}$ Department of Geology, University of Turku FIN-20014 Turku, Finland
}

Received 2 July 2004; accepted 6 July 2005

\section{Abstract}

Compared with present-day global plate tectonics, Archaean and Palaeoproterozoic plate tectonics may have involved faster moving, hotter plates that accumulated less sediment and contained a thinner section of lithospheric mantle. This scenario also fits with the complex geodynamic evolution of the Fennoscandian Shield from 2.06 to 1.78 Ga when rapid accretion of island arcs and several microcontinent-continent collisions in a complex array of orogens was manifested in short-lived but intense orogenies involving voluminous magmatism. With a few exceptions, all major ore deposits formed in specific tectonic settings between 2.06 and $1.78 \mathrm{Ga}$ and thus a strong geodynamic control on ore deposit formation is suggested.

All orogenic gold deposits formed syn- to post-peak metamorphism and their timing reflects the orogenic younging of the shield towards the SW and west. Most orogenic gold deposits formed during periods of crustal shortening with peaks at 2.72 to $2.67,1.90$ to 1.86 and 1.85 to $1.79 \mathrm{Ga}$.

The ca. 2.5 to $2.4 \mathrm{Ga} \mathrm{Ni-Cu} \pm$ PGE deposits formed both as part of layered igneous complexes and associated with mafic volcanism, in basins formed during rifting of the Archaean craton at ca. 2.5 to $2.4 \mathrm{Ga}$. Svecokarelian ca. 1.89 to $1.88 \mathrm{Ga} \mathrm{Ni-Cu}$ deposits are related to mafic-ultramafic rocks intruded along linear belts at the accretionary margins of microcratons.

All major VMS deposits in the Fennoscandian Shield formed between 1.97 and $1.88 \mathrm{Ga}$, in extensional settings, prior to basin inversion and accretion. The oldest "Cyprus-type" deposits were obducted onto the Archaean continent during the onset of convergence. The Pyhäsalmi VMS deposits formed at 1.93 to $1.91 \mathrm{Ga}$ in primitive, bimodal arc complexes during extension of the arc. In contrast, the Skellefte VMS deposits are 20 to 30 million years younger and formed in a strongly extensional intra-arc region that developed on continental or mature arc crust. Deposits in the Bergslagen-Uusimaa belt are similar in age to the Skellefte deposits and formed in a microcraton that collided with the Karelian craton at ca. 1.88 to 1.87 Ga. The Bergslagen-

\footnotetext{
* Corresponding author.

E-mail address: par.weihed@1tu.se (P. Weihed).
} 
Uusimaa belt is interpreted as an intra-continental, or continental margin back-arc, extensional region developed on older continental crust.

Iron oxide-copper-gold (IOCG) deposits are diverse in style. At least the oldest mineralizing stages, at ca. $1.88 \mathrm{Ga}$, are coeval with calc-alkaline to monzonitic magmatism and coeval and possibly cogenetic subaerial volcanism more akin to continental arcs or to magmatic arcs inboard of the active subduction zone. Younger mineralization of similar style took place when S-type magmatism occurred at ca. 1.80 to $1.77 \mathrm{Ga}$ during cratonization distal to the active $\mathrm{N}-\mathrm{S}$-trending subduction zone in the west. Possibly, interaction of magmatic fluids with evaporitic sequences in older rift sequences was important for ore formation.

Finally, the large volumes of anorthositic magmas that characterize the Sveconorwegian Orogeny formed a major concentration of Ti in the SW part of the Sveconorwegian orogenic belt under granulite facies conditions, about 40 million years after the last regional deformation of the Sveconorwegian Orogeny, between ca. 930 and 920 Ma.

(C) 2005 Elsevier B.V. All rights reserved.

Keywords: Palaeoproterozoic; Fennoscandian Shield; VMS; Orogenic gold; Iron oxide-copper-gold (IOCG); Anorthosite; Titanium deposit

\section{Introduction}

The Fennoscandian Shield forms the north-westernmost part of the East European craton and constitutes large parts of Finland, NW Russia, Norway, and Sweden (Fig. 1). The oldest rocks yet found in the shield have been dated at $3.5 \mathrm{Ga}$ (Huhma et al., 2004) and major orogenies took place in the Archaean and Palaeoproterozoic. Younger Meso- and Neoproterozoic crustal growth took place mainly in the western part, but apart from the anorthositic Ti-deposits described in this paper, no major ore deposits are related to rocks of this age. The western part of the shield was reworked during the Caledonian Orogeny.

Economic mineral deposits are largely restricted to the Palaeoproterozoic parts of the shield. Although Ni-PGE deposits, orogenic gold deposits, and some very minor VMS deposits occur in the Archaean, virtually all economic examples of these deposit types are related to Palaeoproterozoic magmatism, deformation and fluid flow. Besides these major deposit types, the Palaeoproterozoic part of the shield is also known for its Fe-oxide deposits, including the famous Kiruna-type Fe-apatite deposits. The genesis of these deposits is still much debated and both magmatic segregation (e.g., Nyström and Henriquez, 1994) and hydrothermal (e.g., Hitzman et al., 1992) origin have been advocated. The Kiruna-type Fe-apatite deposits have recently also been suggested to form an end member of the disparate family of iron oxidecopper-gold (IOCG) deposits (cf. Hitzman et al., 1992; Hitzman, 2000; Porter, 2000; Williams et al.,
2003). $\mathrm{Cu}-\mathrm{Au}$ deposits, with a large tonnage and low grade (e.g., Aitik), are associated with intrusive rocks in the northern part of the Fennoscandian Shield. These deposits have been described as porphyry style deposits or as hybrid deposits with features that also warrant classification as iron oxide-copper-gold (IOCG) deposits (Weihed, 2001; Wanhainen et al., 2003).

In this paper, we discuss the deposit types mentioned above, including the important Mesoproterozoic anorthosite-hosted $\mathrm{Ti}$ deposits. Although still much debated both the Kiruna-type Fe-apatite deposits and the intrusion related $\mathrm{Cu}-\mathrm{Au}$ deposits are here discussed as IOCG deposits. The emphasis is on the geodynamic aspects of ore formation. The deposits are discussed in terms of their tectonic setting and relationship to the overall geodynamic evolution of the shield. Also considered are deposit-scale structural features and their relevance for the understanding of the ore genesis.

\section{The geodynamics of ore formation in the Precambrian}

Precambrian ore deposits have much in common with more recent deposits. There are some notable differences, such as the virtual restriction of komatiitehosted deposits to the Archaean and Early Proterozoic, and the absence of Pb-rich VMS deposits and the scarcity of economic porphyry copper deposits in Archaean and Palaeoproterozoic granite-greenstone 


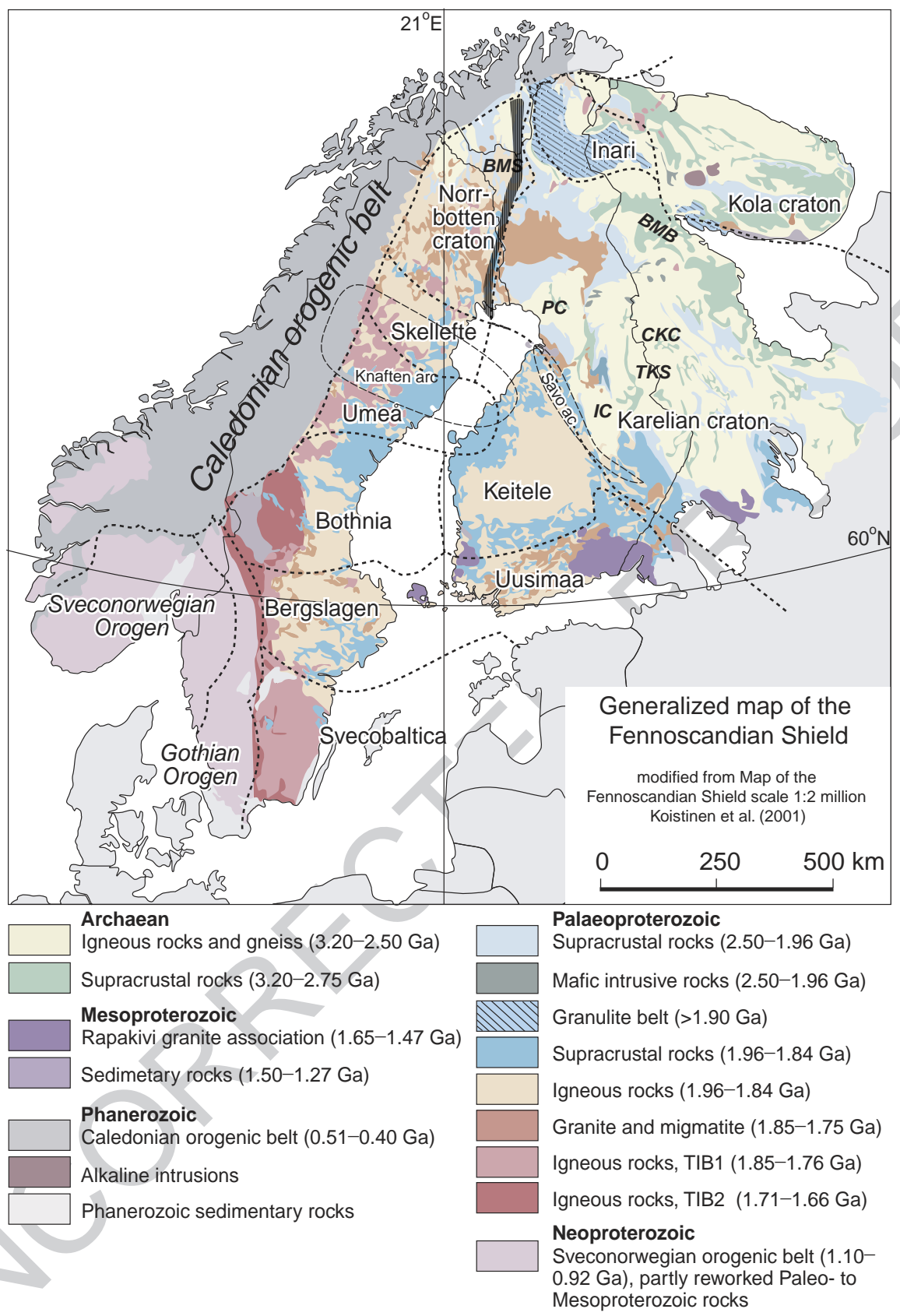

Fig. 1. Simplified geological map of the Fennoscandian Shield with major tectono-stratigraphic units discussed in text (after Lahtinen et al., 2005). Map adapted from Koistinen et al. (2001). BMB =Belomorian Mobile Belt, $\mathrm{CKC}=$ Central Karelian Complex, IC $=\mathrm{Iisalmi}$ Complex, $\mathrm{PC}=$ Pudasjärvi Complex, TKS=Tipasjärvi-Kuhmo-Suomussalmi greenstone complex. Shaded area, BMS=Bothnian Megashear.

107 terranes. However, in terms of their overall character108 istics, there is little to distinguish an Archaean or 109 Palaeoproterozoic VMS and an Archaean or Palaeo- proterozoic orogenic gold deposit from their more 110 modern counterparts. At first sight, this is surprising 111 because physical and chemical conditions in the 112 
113 Archaean (and Palaeoproterozoic?) mantle and crust

114 should have been very different from those of today.

115 Although we can expect the geodynamic processes to

116 have remained constant through time, the conditions

117 in which they have operated have changed. The man-

118 tle was hotter and this would have led to more active

119 and voluminous magmatism (Arndt et al., 1997). At

120 spreading centres (Sleep and Windley, 1982), in man-

121 tle plumes (Herzberg, 1992; Nisbet et al., 1993) and

122 above subduction zones (Parman et al., 2001; Arndt,

123 2003), the degree of mantle melting would have been

124 greater and the magmas produced would have had

125 more magnesian compositions. At spreading centres,

126 the higher degree of mantle melting produced thicker

127 oceanic crust. According to the estimates of Sleep and

128 Windley (1982) and Vlaar (1986), Archaean oceanic

129 crust was 20 to $30 \mathrm{~km}$ thick, compared with 6 to $8 \mathrm{~km}$

130 today. We are not sure how this crust subducted, but

131 subduct it probably did, because rocks similar to those

132 found in modern island arcs and convergent margins

133 are recognized in most Archaean greenstone belts.

134 Plate tectonics, though evolving under different con-

135 ditions, appear to have been operating in the 136 Archaean.

137 Thus, it is important when interpreting the forma-

138 tion of Archaean and Palaeoproterozoic ore deposits

139 that the likely conditions in the crust and upper

140 mantle at the time, and the uncertainties about

141 them, are taken into account. Inevitably, the evidence

142 is speculative, but the following paragraphs offer a

143 reasonable scenario.

144 At an Archaean oceanic ridge or back-arc basin

145 spreading centre, with no significant sub-crustal litho-

146 sphere, the geothermal gradient across a $30 \mathrm{~km}$-thick

147 Archaean oceanic crust, from $<5^{\circ} \mathrm{C}$ to at most $50^{\circ} \mathrm{C}$ on

148 the ocean floor, to approximately $1400^{\circ} \mathrm{C}$ at the base of

149 the crust, would have been 45 to $46^{\circ} \mathrm{C} / \mathrm{km}$, far less than

150 the ca. $200{ }^{\circ} \mathrm{C} / \mathrm{km}$ gradient, from $<5$ to $1200^{\circ} \mathrm{C}$, across

151 the $6 \mathrm{~km}$ thickness of modern oceanic crust. In a

152 modern mid-ocean ridge or back-arc setting, magma

153 chambers located at shallow levels at the spreading

154 centre drive the fluid circulation. Although the geome-

155 try of the magmatic plumbing system in the thicker

156 oceanic crust of an Archaean spreading centre is

157 unknown, the thicker crust, lower geothermal gradient

158 and faster spreading rate would probably have com-

159 bined to distribute magmatic heat sources both deeper

160 and more dispersed. Only the uppermost few $\mathrm{km}$ of the oceanic crust interact with seawater and become hydrated (de Wit et al., 1987). This interval represents a significant fraction of $6 \mathrm{~km}$-thick modern oceanic crust but only a small fraction of thicker Archaean oceanic crust. Thus the temperature of fluid circulating in the crust at Archaean spreading centres would probably have been lower than nowadays.

Just before subduction, the modern oceanic plate consists of a thin layer of sediments, thin, largely hydrated oceanic crust and a thick section of mantle lithosphere. Faster moving, hotter Archaean plates accumulated less sediment and contained a thinner section of mantle lithosphere (Sleep and Windley, 1982). To initiate subduction, the basaltic section of the crust must convert, at least in part, to dense eclogite. It is not clear how this happens, even in the modern situation. If the lower parts of $30 \mathrm{~km}-$ thick Archaean crust were transformed to eclogite, this large volume of relatively cold, dense rock would have acted as a sinker, dragging down the rest of the slab, despite the thinner mantle portion of the lithosphere. The dips of Archaean subduction zones may have been high (Russell and Arndt, 2005), not low, as is commonly proposed (e.g., Karsten et al., 1996; Foley et al., 2003). Hinge retreat or slab roll-back might have been common. In a subduction zone, the relatively small proportion of hydrated crust would have become sandwiched between hot overlying mantle and the cold, thick lower part of the subducted crust. Perhaps Archaean oceanic crust was not always totally subducted. The partially hydrated, basalt-rich and less dense upper parts may have been obducted onto growing arcs or continents while the dense eclogitized lower parts plunged back into the mantle or, alternatively, the lower ultramafic cumulate part of a differentiated crust may have delaminated and the upper section, composed of hydrated basaltic rocks, may have accreted to the growing island arc (Foley et al., 2003).

Fluids released by dehydration of subducting crust would have passed into a hot, overlying Archaean mantle wedge. These fluids contained little of the sedimentary component that dominates modern fluids and they interacted with peridotite in the mantle wedge that was highly depleted in the basaltic component because of the generally high degree of partial melting. This resulted in water-fluxed melting of a refractory mantle source. The magmas produced may
161

162

163

164

165

166

167

168

169

170

171

172

173

174

175

176

177

178

179

180

181

182

183

184

185

186

187

188

189

190

191

192

193

194

195

196

197

198

199

200

201

202

203

204

205

206

207

208 
209 have been boninitic in character, rich in $\mathrm{Mg}$, and poor 210 in $\mathrm{Fe}$ and incompatible trace elements. These magmas 211 would have ascended until they reached the crust of 212 the underthrust plate. There they pooled, fractionated, 213 degassed and perhaps provoked partial melting of the 214 crustal rocks.

215 Some aspects of Archaean island arc successions 216 are consistent with this scenario. Sequences in the 217 Abitibi Belt of Canada (see Thurston and Ayres, 218 2004, for a recent review) contain both tholeiitic and 219 calc-alkaline members, but the calc-alkaline rocks are 220 poorer in alkalis than their modern counterparts. More 221 significantly, Archaean arcs contain a bimodal volca222 nic suite comprising basalts and dacite-rhyolites. True 223 calc-alkaline andesites, and especially rocks contain224 ing abundant, complexly zoned or eroded plagioclase 225 phenocrysts like modern calc-alkaline andesites, are 226 rare to absent. Boninites, though reported, also seem 227 to be rare, perhaps because the crust formed an effec228 tive filter that prevented the passage to the surface of 229 dense, water-rich magmas.

230 The characteristics of hydrothermal systems on 231 Archaean and Proterozoic island arcs and back-arc 232 basins are a matter of speculation. Fluids may have 233 been hotter or cooler than in modern subduction234 related settings, depending on the geometry of the 235 crust and the distribution of heat sources. Fluid fluxes 236 may have been high, due to rapid dehydration of the 237 upper part of the magnesian, serpentine-rich crust as it 238 was dragged rapidly into hot Archaean or Proterozoic 239 mantle. A clear difference would be a scarcity of 240 sediment-hosted deposits like those in Japan and 241 New Brunswick (Allen et al,, 2002).

242 Continental crust formed episodically during the 243 Archaean and Proterozoic. Compilations of reliable 244 ages obtained on crustal rocks, and from detrital 245 zircons in large rivers, produce age spectra character246 ized by the presence of large peaks at 2.7, 2.5, 2.1 and 247 about 1.9 to $1.8 \mathrm{Ga}$ (Goldstein et al., 1997; Condie, 248 2004; Nelson, 2004). Although some authors interpret 249 these peaks as the times of supercontinent formation, 250 arguments can be advanced that suggest that they 251 represent periods of accelerated mantle convection 252 and enhanced crustal growth, as could have been the 253 case in the Fennoscandian Shield. In many regions, 254 the peak of granitoid emplacement, the event that is 255 recorded by $\mathrm{U}-\mathrm{Pb}$ zircon ages, is preceded by about 25630 million years by the eruption of voluminous mafic-ultramafic volcanic rocks (Nelson, 2004). In the southern Superior Province of Canada, in the Yilgarn of Australia, in Brazil, Zimbabwe and in parts of the Aldan Shield in Siberia, komatiites and basalts are dated from 2.73 to $2.70 \mathrm{Ga}$ and the peak of granite emplacement at around $2.70 \mathrm{Ga}$. In the Birimian of West Africa, mafic volcanism is dated at 2.13 $\mathrm{Ga}$ and the granites intruded mainly around $2.07 \mathrm{Ga}$. Abouchami et al. (1990) equate the Birimian mafic volcanism with the enormous ocean plateaux emplaced in the Pacific in the Cretaceous and Boher et al. (1991) interpret the granites as accelerated subduction-related magmatism triggered by the period of enhanced plume activity. This idea has been taken further by Stein and Hofmann (1994) and Condie (2004) who have developed a model in which periods of enhanced plume-dominated mantle convection alternate with periods of plate tectonics.

The physical conditions in the crust and upper mantle when the Archaean and Palaeoproterozoic greenstone belts formed probably correlate with the types of ore deposits they contain. For example, the Abitibi belt in the Canadian Superior Province, which is believed to have formed through the accretion of oceanic crust, oceanic plateaux and island arcs (Card, 1990; Kimura et al., 1993), is the host of numerous large VMS and gold deposits but few Ni-PGE sulphide deposits. In contrast, the greenstone belts of the Yilgarn craton in Western Australia apparently formed through flood volcanism on an older continental basement. This region contains few VMS deposits, abundant gold deposits and hosts, at Kambalda, the type examples of Ni-PGE sulphide deposits in komatiite lava flows (Lesher, 1989). The link between geodynamic context and Ni-PGE mineralization lies in the role that assimilation of continental crust played in the formation of the Kambalda deposits.

The formation of major Neoarchaean VMS, orogenic gold, and Ni-PGE mineralization seems to be restricted to the period ca. 2.74 to $2.69 \mathrm{Ga}$ and appears to correspond to a period of intense intrabasinal mantle plumes and a subsequent global plume-breakout event (Barley et al., 1998). Apart from the low degree of exploration, especially in the eastern part, the obvious lack of major Neoarchaean mineralization in the Fennoscandian Shield could possibly be explained by the age of Neoarchaean greenstone belts. Most of the Fennoscandian greenstone belts seem to be slightly 
305 older than the global Neoarchaean peak in mineraliza-

306 tion and mantle plume activity (e.g., Huhma et al., 307 1999) and, hence, magmatism and hydrothermal activ308 ity might have been less intense and unable to form 309 major metal deposits. This could also explain the lack 310 of major lode gold deposits related to subsequent 311 accretion during peak orogeny. It is also possible that 312 the Fennoscandian Shield exhibits a smaller window 313 into Archaean greenstone terrains, simply due to the 314 local peculiarities of late orogenic evolution, when the 315 thermal regime influences the extent of crustal remelt316 ing and degree of exhumation (Peter Sorjonen-Ward, 317 pers. comm. 2005). Hence, although there is evidence 318 for Neoarchaean greenstone belts formed through the 319 accretion of oceanic crust, oceanic plateaux and 320 island arcs and those formed through flood volcanism 321 on an older continental basement (see below), they 322 apparently do not contain major ore deposits in the 323 Fennoscandian Shield. This is in contrast to the 324 Palaeoproterozoic period of ca. 1.95 to $1.80 \mathrm{Ga}$ in 325 the Fennoscandian Shield, which is intensely miner326 alized and constitutes one of the major Palaeoproter327 ozoic metallogenetic provinces on Earth. Most of the 328 Fennoscandian ore deposits (i.e., VMS, IOCG, and 329 orogenic gold) in the Palaeoproterozoic are related to 330 the formation of island arcs, continental margin arcs, 331 or subsequent accretion to the Archaean (Karelian) 332 craton. This is discussed further below.

\section{3. Tectonic evolution of the Fennoscandian Shield}

\section{3.1. Archaean geology}

335 The Archaean bedrock in the Fennoscandian 336 Shield includes two cratonic nuclei, Karelia and 337 Kola, that were fragmented and further reassembled 338 during the Palaeoproterozoic (Fig. 1). The Karelian 339 craton can be divided into the Belomorian mobile belt 340 and three complexes: Central Karelian, Iisalmi, and 341 Pudasjärvi (Fig. 1). The boundary zone between the 342 Central Karelian Complex and the Belomorian mobile 343 belt was formed by accretion of island arc and con344 tinental fragments to the Karelian core in the Neoarch345 aean (Mints et al., 2001). This boundary zone and the 346 whole Belomorian mobile belt were strongly reacti347 vated in the Palaeoproterozoic (Gaál and Gorbatschev, 348 1987; Bibikova et al., 2001).
Extensive areas of the granitoid and gneiss terrain of eastern Karelia are dated at $2.85 \mathrm{Ga}$, whereas rocks in the central part of the Karelian Province yield ages of ca. 3.05 Ga (Sm-Nd method, Slabunov and Bibikova, 2001). The Vodlozero terrane east of the Lake Onega and the central parts of the Pudasjärvi Complex, with ages up to $3.50 \mathrm{Ga}$, are the oldest parts of the Karelian Craton (Lobach-Zhuchenko et al., 1993; Huhma et al., 2004).

Geochronological studies in NW Russia indicate four generations of greenstones, with age groups of $>3.20$ to $3.10,3.10$ to $2.90,2.90$ to 2.80 and 2.80 to $2.75 \mathrm{Ga}$ (Slabunov and Bibikova, 2001). Based mainly on trace element and isotope geochemistry of the rocks, Svetov (2001) and Puchtel et al. (1999) inferred that the greenstones formed at a convergent ocean-continent boundary by tectonic accretion, and the final collision stages resulted in asymmetric structures of the greenstone belts.

Detailed stratigraphic studies have been conducted in the Archaean Tipasjärvi-Kuhmo-Suomussalmi (TKS) greenstone complex (Fig. 1) in Finland, which therefore serves as a good example of the Archaean evolution (Piirainen, 1988; Papunen et al., 1998; Halkoaho et al., 2000). A bimodal volcanic sequence at the eastern margin of the Suomussalmi greenstone belt evidently belongs to an older supracrustal formation. For example, Vaasjoki et al. (1999) reported a U-Pb age of $2966 \pm 9 \mathrm{Ma}$ for the zircons of felsic volcanic rocks, and consider that there is a time gap of ca. 150 million years between the bimodal volcanic sequence and the lowermost felsic volcanism of the TKS greenstone belt. This time gap is also characterized by deformation, metamorphism, and resetting of $\mathrm{U}-\mathrm{Pb}$ ages of the tonalite-trondhjemitegranitoid (TTG) complex at 2.83 Ga (Luukkonen, 1992).

The lowermost stratigraphic unit of the TKS proper consists of 2.81 to $2.79 \mathrm{Ga}$, felsic to intermediate, subaerial to shallow water-deposited, calc-alkaline volcanic rocks. They occur at the margins of the belt and are geochemically similar to TTG rocks. The overlying volcanic formation is composed of pillowed and massive tholeiitic basalts with interlayers of oxidic and sulphidic Algoma-type banded iron formations. A mafic sill, considered to be comagmatic with the tholeiitic basalts, has been dated at $2790 \pm 18 \mathrm{Ma}$ and a gabbroic variety of a komatiitic 
397 cumulate yielded a zircon U-Pb age of $2757 \pm 20 \mathrm{Ma}$

398 that is so far the only direct age obtained from the

399 ultramafic sequence (Luukkonen, 1992; H. Huhma

400 pers. comm., 1998). A sequence of Al-depleted koma-

401 tiites and komatiitic basalts overlies the tholeiitic

402 basalts. The komatiite formation includes a thick

403 ultramafic olivine cumulate body and several ultra-

404 mafic lenses interpreted as channel facies olivine ad-

405 and meso-cumulates of komatiitic volcanic flows. The

406 cumulate body displays pyroxenitic marginal series

407 against the TTG wallrock and also contains enclaves

408 of tholeiitic basalt and felsic TTG gneisses. The

409 komatiites are overlain by basaltic volcanic rocks

410 and finally by detrital and lahar-like felsic to inter-

411 mediate volcaniclastic deposits, indicating rapid ero-

412 sion and infilling of basins. The volcanic sequence is

413 linked with a mantle hotspot activity in an intracra-

414 tonic basin. The continental crust partially melted in

415 the incipient phase to form the felsic volcanic rock

416 and subsequently contaminated the voluminous erup-

417 tions of komatiitic lavas.

418 The TKS greenstone belt was intruded by grano419 diorites and tonalites with zircon $\mathrm{U}-\mathrm{Pb}$ ages ranging 420 from 2.75 to $2.69 \mathrm{Ga}$ (Luukkonen, 1992) and was 421 isoclinally folded to form a wide synclinorium. Duc422 tile shear zones deformed the belt and acted as con423 duits for ascending metamorphic fluids at ca. 2.75 to $4242.67 \mathrm{Ga}$.

425 3.2. Palaeoproterozoic tectonic evolution from 2.5 to $426 \quad 1.9 \mathrm{Ga}$

427 Several periods of sedimentation and magmatism 428 characterize the Palaeoproterozoic evolution of the 429 shield before the Svecokarelian Orogeny. The 430 Archaean craton of Fennoscandia consolidated after 431 the last major phase of granitoid intrusions at 2.69 $432 \mathrm{Ga}$. During the period 2.5 to $1.9 \mathrm{Ga}$, it underwent 433 several episodes of continental rifting and related, 434 dominantly mafic, magmatism, denudation and sedi435 mentation. These resulted in the formation of vol436 cano-sedimentary sequences, which were deformed 437 during the Svecokarelian Orogeny between 1.9 and $4381.8 \mathrm{Ga}$. The lowermost stratigraphic units consist of 439 clastic sedimentary rocks and bimodal volcanism. An 440 unconformity characterized by polymict conglomer441 ates separates these groups from the overlying epi442 continental sediments and basalts and denotes a period of weathering and quiescence in the tectonic history.

3.2.1. Incipient rifting, volcanism, and emplacement of layered igneous complexes and mafic dykes

445

The beginning of the rifting period between $2.51 \quad 447$ and $2.43 \mathrm{Ga}$ is indicated by intrusion of numerous layered mafic igneous complexes (Alapieti and Lahtinen, 2002). Most of the intrusions are located along the margin of the Archaean granitoid area, either at the boundary against the Proterozoic supracrustal sequence, totally enclosed by Archaean granitoid, or enclosed by a Proterozoic supracrustal sequence.

Alapieti and Lahtinen (2002) divided the intrusions into three types, (1) ultramafic-mafic, (2) mafic and (3) intermediate megacyclic. They also interpret the ultramafic-mafic and the lowermost part of the megacyclic type to have crystallized from a similar, quite primitive magma type, which is characterized by slightly negative initial $\varepsilon_{\mathrm{Nd}}^{(\mathrm{T})}$ values and relatively high $\mathrm{MgO}$ and $\mathrm{Cr}$, intermediate $\mathrm{SiO}_{2}$, and low $\mathrm{TiO}_{2}$ concentrations, resembling the boninitic magma type. The upper parts of megacyclic type intrusions and most mafic intrusions crystallized from an evolved Ti-poor, Al-rich basaltic magma.

Amelin et al. (1995) emphasize the existence of two slightly different age groups of the intrusions, the first with $\mathrm{U}-\mathrm{Pb}$ ages between 2.505 and $2.501 \mathrm{Ga}$, and the second of a slightly younger period, 2.449 to 2.430 $\mathrm{Ga}$. The first includes intrusions along the PolmakPechenga-Imandra-Varzuga greenstone belt, such as Mt. Generalskaya in Pechenga and Imandra, Monchegorsk, Pana and Feodor Tundras in central Kola Peninsula and the second the intrusions in Karelia and the Kola-Finnish Lapland areas (Fig. 2). However, the timing of these intrusions is disputed, as contrasting $\mathrm{U}-\mathrm{Pb}$ ages of $2496 \pm 10$ and $2447 \pm 10$ Ma were recently determined from two different stratigraphic levels of the Mt. Generalskaya intrusion (Bayanova et al., 1999) and similar results have been obtained from the Panski Tundra intrusions (Mitrofanov and Bayanova, 1999).

Amelin et al. (1995) bracketed the U-Pb age of the oldest basaltic volcanism between 2.443 and $2.440 \mathrm{Ga}$, as the volcanic rocks are intruded by a $2441.3 \pm 1.2$ Ma pluton but overlie a $2442.1 \pm 1.4$ Ma pluton. Other age determinations of volcanism in eastern Karelia indicate ages between 2.45 and $2.43 \mathrm{Ga}$. Manninen
448

449

450

451

452

453

454

455

456

457

458

459

460

461

462

463

464

465

466

467

468

469

470

471

472

473

474

475

476

477

478

479

480

481

482

483

484

485

486

487

488

489 


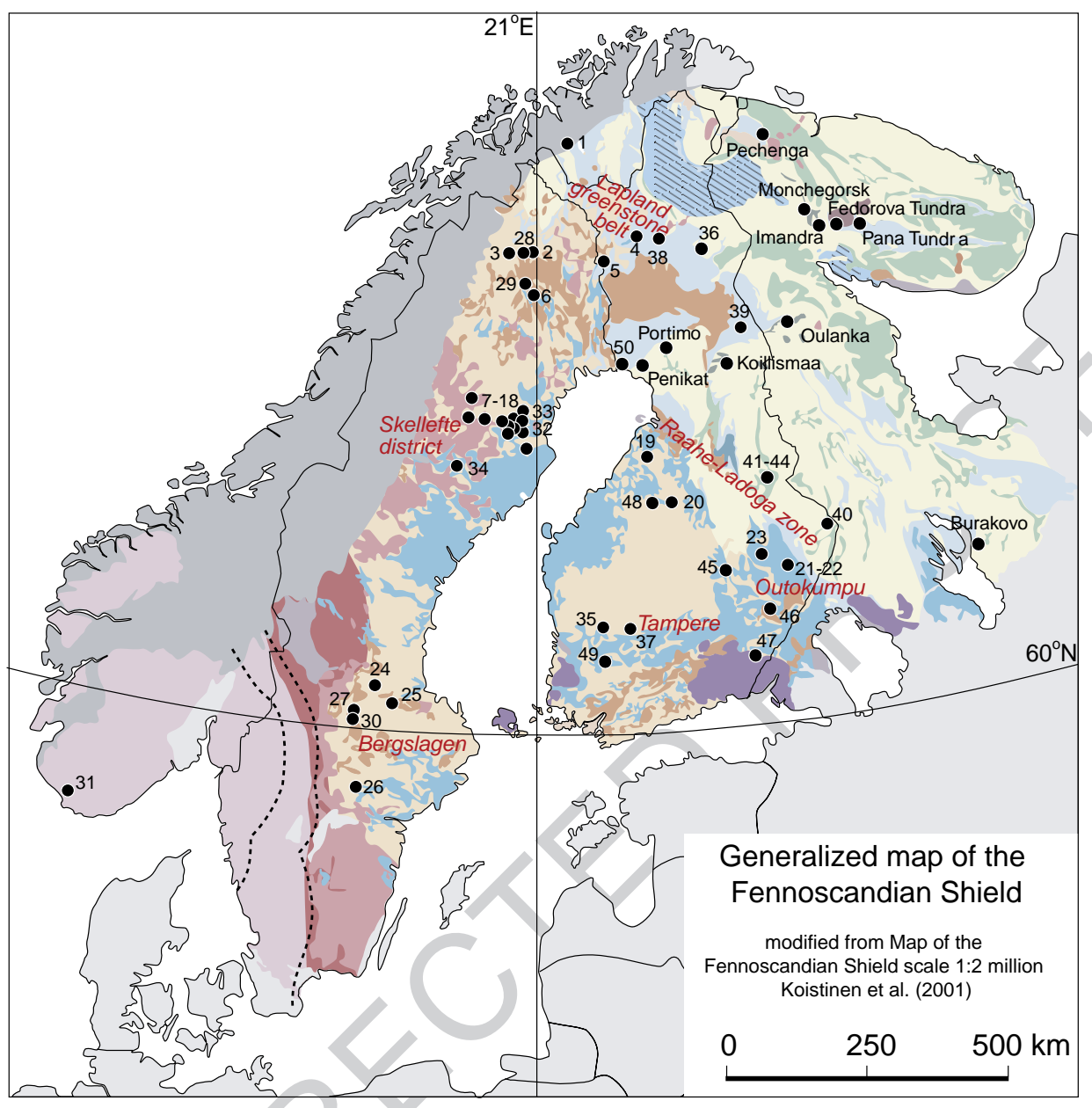

Fig. 2. Simplified geological map of the Fennoscandian Shield with major ore deposits discussed in text indicated. Map adapted from Koistinen et al. (2001). Numbers refer to deposits listed in Table 1. Deposits without numbers are discussed in the text but are not included in Table 1.

490 and Huhma (2001) reported similar ages from the 491 Central Lapland greenstone belt. Geochronological 492 data from Finland and from the Russian part of the 493 shield thus show that large volumes of continental 494 volcanic rocks were erupted contemporaneously with 495 the 2.44 to 2.45 Ga layered intrusions. A number of 496 coeval mafic dykes in the Karelian Craton have ages 497 around $2.44 \mathrm{Ga}$ (Vuollo, 1994). Sm-Nd isotope stu498 dies indicate that boninitic dykes have negative $\varepsilon_{\mathrm{Nd}}^{(\mathrm{T})}$ 499 values from -1.2 to -2.5 , consistent with the values 500 obtained from the layered intrusions (Huhma et al., 501 1990; Alapieti and Lahtinen, 2002).

502 Layered intrusions, mafic dyke swarms, and coeval 503 continental volcanism together suggest mantle plume activity in an extensional setting (Amelin et al., 1995). This model implies extension and crustal uplift before volcanism and subsequent subsidence and formation of graben structures during and after volcanism. Poorly sorted sediments characteristic of graben infill are recorded at this stratigraphic level (Gorbunov et al., 1985). The intense faulting and displacement are related to the late stages of rifting, probably to the cooling and subsidence of the brittle layer of the lithosphere after the buoyant rise of the base of the lithosphere during the active rifting phase (see Alapieti and Lahtinen, 2002). The intrusions were later deformed and metamorphosed during the Svecokarelian Orogeny. 


\section{3.2.2. Evolution between 2.33 and $1.87 \mathrm{Ga}$}

519 The Polmak-Pechenga greenstone belt extends for 520 about $200 \mathrm{~km}$ from northern Finland to NW Russia.

521 The area has been intensely studied since the discov522 ery of the Pechenga $\mathrm{Ni}-\mathrm{Cu}$ deposits in the 1920s, and 523 the review here is mainly based on the work of Hanski 524 (1992), Melezhik (1996), Green and Melezhik (1999) 525 and Barnes et al. (2001). The $2.3 \mathrm{Ga}$, subaerially 526 deposited, andesitic basalts of the lowermost volcanic 527 unit of the Pechenga sequence represent the next 528 episode of magmatic activity in the Fennoscandian 529 Shield (Melezhik, 1996). Conglomerate and a regolith 530 on the Archaean crust underlie these basalts. The 531 conglomerate contains clasts derived from the Mt. 532 Generalskaya layered complex $(2505 \pm 1.6 \mathrm{Ma} \mathrm{U}-$ $533 \mathrm{~Pb}$ age of baddeleyite, Amelin et al., 1995), indicating 534 that the crust had been deeply eroded to expose the 535 intrusion before the onset of volcanism. The Pechenga 536 sequence developed with cyclic sedimentation and 537 volcanism in an intracratonic rift zone, but the volcan538 ism at ca. 2.1 to $2.0 \mathrm{Ga}$ represents a transition from an 539 intracratonic to an intercontinental oceanic rift envir540 onment that developed between 2.00 and $1.97 \mathrm{Ga}$ into 541 an oceanic rift with voluminous sedimentation and 542 volcanism. The Pechenga sequence was subducted 543 between 1.97 and $1.87 \mathrm{Ga}$ and a continent-continent 544 collision followed from 1.87 to $1.80 \mathrm{Ga}$ in the region 545 (Melezhik, 1996). Ultramafic, ferropicritic volcanic 546 rocks (Hanski and Smolkin, 1989; Hanski, 1992), 547 dated at $1,977 \pm 52 \mathrm{Ma}(\mathrm{Sm}-\mathrm{Nd}, \mathrm{Pb}-\mathrm{Pb}$, Hanski, 548 1992) host the Pechenga Ni-Cu deposits. The ferro549 picrites are enriched in LILE, LREE and HFSE and 550 display similarities with the picritic volcanic rocks of 551 the Central Lapland greenstone belt discussed below. 552 Although the idea of a core signature has been sug553 gested for the Fe-rich Archaean to Proterozoic ultra554 mafic volcanic rocks (Puchtel et al., 1999), it has also 555 been argued that the Archaean/Proterozoic picrites 556 were $30 \%$ richer in Fe compared with modern OIB 557 since the mantle was more Fe-rich at that time (Fran558 cis et al., 1999; Barnes et al., 2001).

559 The Central Lapland greenstone belt (CLGB) is the 560 most extensive belt of mafic volcanic rocks and 561 related sedimentary units in Fennoscandia (Fig. 2). 562 The CLGB is divided into seven lithostratigraphic 563 groups (Lehtonen et al., 1998; Hanski et al., 2001a; 564 Vaasjoki, 2001), of which the oldest belong to the 565 intracratonic hotspot-related rift evolution of 2.45 to
$2.43 \mathrm{Ga}$ discussed above. After this phase, epiclastic sedimentary rocks, quartzites, mica schists and minor carbonate rocks were deposited. Räsänen and Huhma (2001) reported ages between 2.45 and 2.22 Ga for mafic magmatism interlayered in the sedimentary sequence, but the extensive 2.2 Ga-old mafic sills represent the main phase of igneous activity, indicating renewed rifting of the underlying craton. The depositional basin became deeper and fine-grained sediments, phyllites and carbonaceous sulphide-bearing black schists were deposited between 2.2 and 2.06 $\mathrm{Ga}$. These are characterized by isotopically heavy carbon with $\delta^{13} \mathrm{C}$ values up to $+18 \%$, which correlate with the global heavy C-isotopes of carbonates of this time span (Karhu, 1993; Melezhik, 1996). The $2058 \pm 4$ Ma Kevitsa mafic-ultramafic intrusion intersects the sequence and provides a minimum age for the sedimentary sequence. The sediments in the basin are overlain by a voluminous, $2.05 \mathrm{Ga}$, ultramafic komatiitic and picritic volcanic belt extending for $350 \mathrm{~km}$ from central Lapland to northern Norway. The komatiites are exceptional in their chemical composition with high Ti concentrations and flat LREEdepleted patterns (Barnes and Often, 1990), whereas the picrites are LREE and HFSE enriched, which indicate mantle hotspot activity (Hanski et al., 2001b).

The overlying mafic submarine volcanic sequences of the CLGB display tectonic contacts against the 2.2 to $2.05 \mathrm{Ga}$ unit, with the contact zone being characterized by serpentinites interpreted as dismembered and overthrust pieces of ocean-floor ophiolites (Hanski, 1997). The submarine volcanic sequence is composed of tholeiitic mafic volcanic rocks and mafic to intermediate volcaniclastic rocks interlayered with fine-grained detrital and chemical sediments. This indicates the existence of oceanic crust, which was obducted to its present position before the intrusion of $1.91 \mathrm{Ga}$ granites. A U-Pb age of ca. $2.015 \mathrm{Ga}$ has been obtained for the upper part of this unit (Rastas et al., 2001).

\subsubsection{Summary of evolution between 2.5 and $1.87 \mathrm{Ga}$}

Intracratonic basin evolution with intermittent volcanism lasted for up to 500 million years with no indications of accretionary phases or formation of major new felsic crust. Recurrent mantle hotspot activity characterizes the period 2.5 to $2.05 \mathrm{Ga}$ with numerous layered intrusions, komatiite and picrite 
613 eruptions in Finnish Lapland at $2.05 \mathrm{Ga}$, and finally

614 the extrusion/intrusion of the Pechenga ferropicrites at

$6151.97 \mathrm{Ga}$. Oceanic crust only formed during the last 616 phase of the extension and was finally obducted dur617 ing accretion and continent-continent collision at ca. 6181.9 to $1.8 \mathrm{Ga}$.

619 Such a long period for the evolution of intracra620 tonic, transient and oceanic basins deviates from the 621 normal time span of Phanerozoic plate tectonic 622 processes where a major intracratonic rifting is fol623 lowed by opening of an ocean in a relatively short 624 period of time. Also the time span of about 30 625 million years that commonly separates the major 626 mafic volcanic episodes from the intrusion of gran627 itoids, as noted above, did not hold in the geotec628 tonic evolution of the Fennoscandian Shield between 6292.5 and $2.0 \mathrm{Ga}$, as several phases of volcanism and 630 mafic intrusions formed without related felsic mag631 matism. This must have been the result of a profound 632 change in mantle convection and interaction between 633 asthenosphere and lithosphere at this time, but dis634 cussion of these processes is beyond the scope of this 635 paper.

\section{3.3. The 1.9 to 1.8 Ga Svecokarelian Orogeny}

637 The most intense crustal growth in the Palaeopro638 terozoic took place during the Svecokarelian/Sveco639 fennian Orogeny (both names occur in the literature) 640 at ca. 1.9 to $1.8 \mathrm{Ga}$. Hietanen (1975) presented the 641 first plate tectonic interpretation of the Svecofennian 642 Orogeny based on the comparison between western 643 North American Cordilleran and the Svecofennian. 644 Gaál (1982) presented a plate tectonic model with a 645 subduction towards ENE and collision at ca. 1.9 Ga. 646 Gaál and Gorbatschev (1987) later extended this 647 model. Ward (1987) argued that the scarcity of sub648 duction-related magmatism in the Archaean craton 649 margin and the easterly-directed tectonic transport 650 implied westerly-directed subduction before collision. 651 Gaál (1990) adopted this idea and included a subduc652 tion reversal in his model to account for the volumi653 nous magmatism in central Finland.

654 The ca. 1.95 Ga rocks in the Knaften area (Was655 ström, 1993), south of the Skellefte District in Swe656 den, and the 1.92 Ga primitive island arc rocks in the 657 Savo Belt (Korsman et al., 1997), adjacent to the 658 Archaean craton in Finland (Fig. 1), are the oldest documented Svecofennian units in the shield, but older protoliths $(\sim 2.1$ to $2.0 \mathrm{Ga})$ are inferred from $\mathrm{Nd}$ isotope geochemistry and detrital zircon studies (Lahtinen and Huhma, 1997). Island arc-type volcanic rocks and coeval calc-alkaline granitoids aged 1.90 to $1.87 \mathrm{Ga}$ dominate in the central Fennoscandian Shield. Plutonic rocks in Sweden, aged 1.80 to $1.78 \mathrm{Ga}$ with mixed I- to A-type characteristics, represent the youngest major Palaeoproterozoic magmatism in the central shield. Migmatites with tonalitic leucosome in Finland formed from immature psammites at 1.89 to $1.88 \mathrm{Ga}$, whereas younger migmatites with granite leucosome, and associated S-type granites, formed at 1.86 to $1.82 \mathrm{Ga}$ in the Bothnian Basin and in the southern part of the Svecofennian domain (Lundqvist et al., 1998; Korsman et al., 1999; Rutland et al., 2001; Weihed et al., 2002). The southern Svecofennian domain includes the 1.90 to 1.89 Ga Bergslagen-Uusimaa belt (Fig. 1), which formed, in part, in an intra-arc basin of a mature continental arc (e.g., Kähkönen et al., 1994; Allen et al., 1996a). Metapelite-dominated sedimentary rocks, quartzites and carbonate rocks characterize the southern part of the Svecofennian domain. Plutonism in that area occurred between 1.89 and $1.85,1.84$ and 1.82 , and 1.81 and $1.79 \mathrm{Ga}$. S-type granites and migmatites aged 1.84 to $1.82 \mathrm{Ga}$ form a belt that extends from SE Finland to central Sweden (e.g., Korsman et al., 1999).

Reflection seismic studies in the 1980s indicated possible fossil subduction zones and remnant slabs from subduction immediately south of the Skellefte District in Sweden (BABEL Working Group, 1990). Korja et al. (1993) proposed a mantle underplating model to account for the thick crust in central Finland, whereas Lahtinen (1994) presented a model for the Svecofennian of Finland involving several accretionary units and three collisional stages at 1.91 to 1.90 , 1.89 to 1.88 , and 1.86 to $1.84 \mathrm{Ga}$. Korja (1995) introduced the concept of orogenic collapse to account for the variation in crustal thickness in southern Finland, and Nironen (1997) presented a kinematic plate tectonic model for the Svecofennian Orogen starting with the opening of an ocean at $1.95 \mathrm{Ga}$, followed by progressive accretion of two arc complexes on to the Archaean craton between 1.91 and $1.87 \mathrm{Ga}$. The accretionary orogens are progressively younger towards the west, with the subsequent Gothian Oro-
659

660

661

662

663

664

665

666

667

668

669

670

671

672

673

674

675

676

677

678

679

680

681

682

683

684

685

686

687

688

689

690

691

692

693

694

695

696

697

698

699

700

701

702

703

704

705

706 
707 geny between 1.75 and $1.55 \mathrm{Ga}$. Later reworking of 708 the crust occurred during the Sveconorwegian/Gren709 villian Orogeny at ca. 1.15 to $0.9 \mathrm{Ga}$ (e.g., Gor710 batschev and Bogdanova, 1993; Åhäll and Larson, 711 2000).

712 According to Lahtinen et al. (2003, 2004, 2005) 713 the ca. 2.00 to $1.92 \mathrm{Ga}$ evolution of the shield 714 involved the amalgamation of several microcontinents 715 and island arcs. This included several pre-1.92 Ga 716 cratons, $>2.0 \mathrm{Ga}$ microcontinents, and ca. 2.0 to 717 1.95 Ga island arcs. Previous models have proposed 718 a semi-continuous Svecokarelian/Svecofennian Oro719 geny whereas Lahtinen et al. $(2004,2005)$ define five 720 orogenies for the time period 1.92 to $1.79 \mathrm{Ga}$ and 721 divide this period into a microcontinent accretion 722 stage (1.92 to $1.88 \mathrm{Ga}$ ), and a continent-continent 723 collision stage (1.87 to $1.79 \mathrm{Ga}$ ).

724 The Palaeoproterozoic tectonic evolution of the 725 Karelian craton, the Archaean nucleus of the shield, 726 involved a long period of intracontinental extension 727 between 2.5 and $2.1 \mathrm{Ga}$, finally leading to a conti728 nental break-up at $2.06 \mathrm{Ga}$ as described above. Sub729 sequent convergence and microcontinent accretion 730 (1.92 to $1.88 \mathrm{Ga})$ resulted in the collision of the 731 Kola and Karelian cratons (cf. Fig. 1) that, according 732 to Lahtinen et al. (2004, 2005), led to the Lapland733 Kola Orogeny. The collision of the Karelian craton 734 with the Norrbotten craton (the Archaean rocks west 735 of the Bothnian megashear as defined by Berthelsen 736 and Marker, 1986) and the Keitele microcontinent, 737 and the docking of the Bothnia microcontinent (Fig. 738 1), led to the Lapland-Savo Orogeny. The collision of 739 the Bergslagen microcontinent with the newly formed 740 Archaean-Palaeoproterozoic complex led to the Fen741 nian Orogeny.

742 During subsequent continent-continent collision, 743 two subduction zones, in the south and in the west, 744 were active between 1.86 and $1.81 \mathrm{Ga}$. According to 745 this model (Lahtinen et al., 2004, 2005), subduction 746 was followed by oblique collision of Fennoscandia 747 with Sarmatia between 1.84 and $1.80 \mathrm{Ga}$, defining the 748 Svecobaltic Orogeny. A crustal-scale shear zone 749 divided the Svecobaltic Orogen into two distinct com750 pressional regimes; (1) a retreating subduction zone at 751 an Andean-type margin in the SW, and (2) a trans752 pressional regime in the SE. A collision between 753 Amazonia and Fennoscandia affected the central and 754 northern parts of the western edge of the Fennoscan- dian Shield at 1.82 to $1.80 \mathrm{Ga}$ and is defined as the Nordic Orogeny. Orogenic collapse and the stabilization of the Fennoscandian Shield essentially occurred between 1.79 and $1.77 \mathrm{Ga}$. This was followed by younger orogenies in the SW and a westward growth of the shield.

\section{Ore-forming processes-relationship between ore deposits and geodynamic setting}

761

762

In the Fennoscandian Shield, the major deposit types are excellent guides to the geodynamic processes that operated in the Archaean and Proterozoic. Here we discuss five important deposit types and emphasize their relationship with the evolution of the shield. All deposit types contain ores that are or have been economic and that today are actively explored for in the shield. The five deposit types are (1) $\mathrm{Ni}-\mathrm{Cu}-\mathrm{PGE}$ deposits, (2) VMS ( $\mathrm{Zn}-\mathrm{Cu}-\mathrm{Pb} \pm$ $\mathrm{Au} \pm \mathrm{Ag}$ ) deposits, (3) orogenic gold deposits, (4) iron oxide-copper-gold deposits (IOCG), including Kiruna-type $\mathrm{Fe}$ deposits and (5) $\mathrm{Fe}-\mathrm{Ti}$ oxides in anorthosites. Major deposits in the Fennoscandian Shield are listed in Table 1 and their distribution is shown in Fig. 2.

\section{1. $\mathrm{Ni}-\mathrm{Cu}-\mathrm{PGE}$ deposits}

$\mathrm{Ni}-\mathrm{Cu} \pm \mathrm{PGE}$ deposits occur in several different settings within the shield. Mining of $\mathrm{Ni}$ as the main commodity has mainly occurred in NW Russia, (e.g., Pechenga), in Finland (e.g., Kotalahti, Hitura and Vammala) and only to a lesser extent in Sweden (e.g., Lainejaur). It is possible to subdivide these deposits on the basis of their geodynamic setting into the following types: (1) deposits in Archaean greenstone belts $(2.74 \mathrm{Ga})$, (2) deposits in mafic layered intrusions (2.49 to $2.45 \mathrm{Ga}$ ), (3) deposits in Palaeoproterozoic greenstone belts $(2.2$ to $2.05 \mathrm{Ga})$, (4) deposits in Palaeoproterozoic ophiolite complexes $(1.97 \mathrm{Ga}),(5)$ deposits associated with rift-related ultramafic volcanism (1.97 Ga), (6) deposits in Svecofennian orogenic mafic-ultramafic intrusions (1.88 $\mathrm{Ga}$ ) and (7) deposits in post-orogenic diabase dykes. Of these, type four is discussed in the VMS section and type seven is minor and will not be discussed further.
778

763

764

765

766

767

768

769

770

771

772

773

774

775

776

777

779

780

781

782

783

784

785

786

787

788

789

790

791

792

793

794

795

796

797 
Table

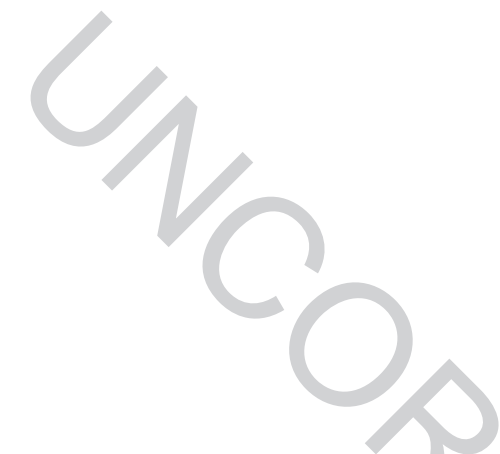

Grade and pre-mining tonnage of selected ${ }^{\mathrm{a}}$ ore deposits in the Fennoscandian Shield

\begin{tabular}{|c|c|c|c|c|c|c|c|c|c|c|c|c|c|c|}
\hline & Type $^{\mathrm{b}}$ & $\begin{array}{l}\text { Ton. } \\
\text { (Mt) }\end{array}$ & $\begin{array}{l}\mathrm{Cu} \\
\% \\
\end{array}$ & $\begin{array}{l}\mathrm{Zn} \\
\%\end{array}$ & $\begin{array}{l}\mathrm{Pb} \\
\%\end{array}$ & $\begin{array}{l}\text { Co } \\
\%\end{array}$ & $\begin{array}{l}\mathrm{Au} \\
\mathrm{ppm}\end{array}$ & $\begin{array}{l}\mathrm{Ag} \\
\mathrm{ppm}\end{array}$ & $\begin{array}{l}\mathrm{Fe} \\
\%\end{array}$ & $\begin{array}{l}\mathrm{Ni} \\
\% \\
\end{array}$ & $\begin{array}{l}\mathrm{Cr} \\
\%\end{array}$ & $\begin{array}{l}\mathrm{TiO}_{2} \\
\%\end{array}$ & Status & Reference $^{c}$ \\
\hline 1) Bidjovagge & $\mathrm{Cu}-\mathrm{Au}$ & 2 & 1.2 & - & & 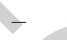 & 3.6 & - & - & - & - & - & Closed mine & Ettner et al. (1994) \\
\hline 2) Viscaria & Strat. $\mathrm{Cu}$ & 12.54 & 2.29 & - & & & & - & - & - & - & - & Closed mine & Martinsson et al. (1997) \\
\hline 3) Pahtohavare & $\mathrm{Cu}-\mathrm{Au}$ & 1.7 & 1.9 & - & - & - & 0.9 & - & - & - & - & - & Closed mine & Lindblom et al. (1996) \\
\hline 4) Saattopora & $\mathrm{Cu}-\mathrm{Au}$ & 2.2 & 0.28 & - & - & 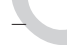 & 3.29 & - & - & - & - & - & Closed mine & Grönholm (1999) \\
\hline 5) Laurinoja & $\mathrm{Cu}-\mathrm{Au}$ & 4.6 & 0.88 & - & - & - & 0.95 & - & - & - & - & - & Closed mine & Hiltunen (1982) \\
\hline 6) Aitik & Porph. & 1600 & 0.4 & - & - & - & 0.2 & 4 & - & - & - & - & Active mine & Wanhainen et al. (2003) \\
\hline 7) Boliden & VMS & 8.3 & 1.4 & 0.9 & 0.3 & - & 15.5 & 50 & - & - & - & - & Closed mine & Bergman Weihed et al. (1996) \\
\hline 8) Långdal & VMS & 4.4 & 0.1 & 5.8 & 1.7 & - & 1.9 & 149 & & - & - & - & Closed mine & Allen et al. (1996a) \\
\hline 9) Långsele & VMS & 12.0 & 0.6 & 3.9 & 0.3 & - & 0.9 & 25 & - & - & - & - & Closed mine & Allen et al. (1996a) \\
\hline 10) Renström & VMS & $>9$ & 0.8 & 6.5 & 1.5 & - & 2.8 & 155 & - & - & - & - & Active mine & Allen et al. (1996a) \\
\hline 11) Petiknäs $S$ & VMS & 6.5 & 1.1 & 4.8 & 0.9 & - & 2.3 & 108 & - & - & - & - & Active mine & Allen et al. (1996a) \\
\hline 12) Udden & VMS & 6.7 & 0.4 & 4.3 & 0.3 & - & 0.7 & 36 & - & & - & - & Closed mine & Allen et al. (1996a) \\
\hline 13) Maurliden W. & VMS & 6.9 & 0.2 & 3.4 & 0.4 & - & 0.9 & 49 & - & & & - & Active mine & Allen et al. (1996a) \\
\hline 14) Näsliden & VMS & 4.6 & 1.1 & 3.0 & 0.3 & - & 1.3 & 35 & - & - & & - & Closed mine & Allen et al. (1996a) \\
\hline 15) Rakkejaur & VMS & $>20$ & 0.3 & 2.4 & - & 1.0 & 50 & - & - & - & & - & Closed mine & Allen et al. (1996a) \\
\hline 16) Kristineberg & VMS & $>22$ & 1.0 & 3.2 & 0.4 & - & 1.0 & 32 & - & - & - & & Active mine & Allen et al. (1996a) \\
\hline 17) Rävlidmyran & VMS & 7.5 & 1.0 & 3.9 & 0.6 & - & 0.8 & 51 & - & - & - & & Closed mine & Allen et al. (1996a) \\
\hline 18) Rudtjebäcken & VMS & 4.7 & 0.9 & 2.9 & 0.1 & - & 0.3 & 10 & - & - & - & - & Closed mine & Allen et al. (1996a) \\
\hline 19) Vihanti & VMS & 28.1 & 0.48 & 5.12 & 0.36 & - & 0.49 & 25 & - & - & - & - & Closed mine & Helovuori (1979) \\
\hline 20) Pyhäsalmi & VMS & 71 & 0.79 & 2.47 & - & - & 0.4 & 15 & - & - & - & - & Active mine & Weihed (2001) \\
\hline 21) Keretti & VMS & 28.5 & 3.8 & 1.07 & - & 0.24 & 0.8 & 8.9 & - & 0.17 & - & - & Closed mine & Gaál (1985) \\
\hline 22) Vuonos & VMS & 5.9 & 2.45 & 1.6 & - & 0.15 & 0.1 & 11 & - & 0.17 & - & - & Closed mine & Gaál (1985) \\
\hline 23) Luikonlahti & VMS & 7.5 & 0.99 & 0.5 & - & 0.11 & - & - & - & 0.09 & - & - & Closed mine & Gaál (1985) \\
\hline 24) Falun & VMS & 28.1 & $\sim 3$ & 4 & 1.5 & - & $\sim 3^{\mathrm{d}}$ & $\sim 20$ & - & - & - & - & Closed mine & Allen et al. (1996b) \\
\hline 25) Garpenberg & VMS & 21.5 & 0.3 & 5.3 & 3.3 & - & 0.65 & 98 & - & - & - & - & Active mine & Allen et al. (1996b) \\
\hline 26) Zinkgruvan & VMS & $60 ?$ & - & 10 & 2 & - & - & $50-100$ & - & - & - & - & Active mine & Allen et al. (1996b) \\
\hline 27) Saxberget & VMS & 6.8 & 0.9 & 7.1 & 2.2 & - & 0.4 & 42 & - & - & - & - & Closed mine & Allen et al. (1996b) \\
\hline 28) Kiirunavaara & $\mathrm{FeOx}$ & $>2000$ & - & - & - & - & - & - & $>60$ & & - & - & Active mine & Martinsson (1997) \\
\hline
\end{tabular}




\begin{tabular}{|c|c|c|c|c|c|c|c|c|c|c|c|c|c|c|c|}
\hline $\mathrm{t} 1.32$ & 29) Malmberget & $\mathrm{FeOx}$ & $>660$ & - & - & - & - & - & $51-61$ & - & - & - & - & Active mine & Martinsson (1997) \\
\hline $\mathrm{t} 1.33$ & 30) Grängesberg & $\mathrm{FeOx}$ & $>198$ & - & - & - & - & - & - & $58-64$ & & - & - & Closed mine & Allen et al. (1996b) \\
\hline $\mathrm{t} 1.34$ & 31) Tellnes & Ti & $>300$ & - & - & - & - & - & - & - & - & - & 18 & Active mine & Charlier (this volume) \\
\hline $\mathrm{t} 1.35$ & 32) Björkdal & Active mine & $>20$ & - & - & - & - & 2.6 & - & - & - & - & - & Active mine & Weihed et al. (2003) \\
\hline $\mathrm{t} 1.36$ & 33) Àkerberg & Active mine & 1.1 & - & - & - & - & 3 & - & - & - & - & - & Closed mine & Sundblad (2003) \\
\hline $\mathrm{t} 1.37$ & 34) Svartliden & Active mine & 2.5 & - & - & - & - & 5.4 & - & - & - & - & - & Active mine & Sundblad (2003) \\
\hline $\mathrm{t} 1.38$ & 35) Haveri & VMS & 1.5 & 0.37 & - & - & - & 2.8 & - & - & - & - & - & Closed mine & Eilu et al. (2003) \\
\hline \multirow[t]{2}{*}{$\mathrm{t} 1.39$} & 36) Pahtavaara & Active mine & $>3$ & - & - & - & - & 3 & - & - & - & - & - & Active mine & Eilu et al. (2003) \\
\hline & 37) Kutemajärvi & Epith. Au & 2.0 & - & - & - & - & 9 & - & - & - & - & - & Closed mine & Poutiainen and Grönholm (1996) \\
\hline t1.41 & 38) Suurikuusikko & Active mine & 17 & & - & - & - & 5.2 & - & - & - & - & - & Prospect & Eilu et al. (2003) \\
\hline $\mathrm{t} 1.42$ & 39) Juomasuo & Active mine & 1.8 & - & - & - & 0.2 & 3 & - & - & - & - & - & Closed mine & Eilu et al. (2003) \\
\hline $\mathrm{t} 1.43$ & 40) Pampalo & Active mine & 1.2 & & & - & - & 8 & - & - & - & - & - & Closed mine & Eilu et al. (2003) \\
\hline $\mathrm{t} 1.44$ & 41) Peura-aho & $\mathrm{Ni}-\mathrm{Cu}$ & 0.26 & 0.24 & & - & - & - & - & - & - & 0.58 & - & Prospect & Kurki and Papunen (1985) \\
\hline $\mathrm{t} 1.45$ & 42) Hietaharju & $\mathrm{Ni}-\mathrm{Cu}$ & 0.24 & 0.43 & & & - & - & - & - & 0.86 & - & - & Prospect & Kurki and Papunen (1985) \\
\hline t1.46 & 43) Arola & $\mathrm{Ni}-\mathrm{Cu}$ & 1.52 & - & & & - & - & - & - & 0.56 & - & - & Prospect & Kurki and Papunen (1985) \\
\hline \multirow[t]{3}{*}{$\mathrm{t} 1.47$} & 44) Sika-aho & $\mathrm{Ni}-\mathrm{Cu}$ & 0.18 & - & & & & - & - & - & 0.66 & - & - & Prospect & Kurki and Papunen (1985) \\
\hline & 45) Kotalahti & $\mathrm{Ni}-\mathrm{Cu}$ & 13 & 0.27 & & & & - & - & - & 0.72 & - & - & Closed mine & Papunen and Gorbunov (1985) \\
\hline & 46) Laukunkangas & $\mathrm{Ni}-\mathrm{Cu}$ & 6.7 & 0.22 & & & & - & - & - & 0.76 & - & - & Closed mine & Papunen and Gorbunov (1985) \\
\hline \multirow[t]{3}{*}{$\mathrm{t} 1.50$} & 47) Telkkälä & $\mathrm{Ni}-\mathrm{Cu}$ & 0.6 & 0.35 & - & & & & - & - & 1.41 & - & - & Closed mine & Papunen and Vorma (1985) \\
\hline & 48) Hitura & $\mathrm{Ni}-\mathrm{Cu}$ & 13 & 0.2 & - & & & - & - & - & 0.59 & - & - & Closed mine & Papunen and Gorbunov (1985) \\
\hline & 49) Vammala & $\mathrm{Ni}-\mathrm{Cu}$ & 7.4 & 0.4 & - & - & & - & - & - & 0.69 & - & - & Closed mine & Papunen and Gorbunov (1985) \\
\hline $\mathrm{t} 1.53$ & 50) Kemi & $\mathrm{Cr}$ & $>236$ & - & - & - & & - & - & - & - & 26 & - & Active mine & Alapieti et al. (1989) \\
\hline
\end{tabular}

t1.54 The genesis of some deposits is still debated, this is discussed further in the text.

a This table lists all major deposits, or deposits discussed in the text, of each type in the Fennoscandian Shield where deposit data are available. Data for deposits 4, 5, 19, 20, 21, 22, 23, 35-50 from the Geological Survey of Finland deposit database, data for deposit 1, 2, 7-18 from Weihed (2001), data for deposit 6 from Boliden Mineral AB, data for deposits 24

27 from Allen et al. (1996b), data for deposits 28-30 from Geological Survey of Sweden mineral deposit database and data for deposit 31 from Charlier (2005).

b Abbreviations: Strat. $\mathrm{Cu}=$ Stratiform $\mathrm{Cu}$ deposits; Porph. $=$ Porphyry type deposit; VMS =Volcanogenic massive sulphide deposit; FeOx=Fe-oxide deposit; Orog. Au=Orogenic t1.56 gold deposit; Epith. Au=Epithermal Au deposit.

${ }^{c}$ There is only one reference for each deposit listed in the table. Where possible this is a recent reference containing more references to the deposit concerned. t1.58 ${ }^{\mathrm{d}}$ Grade for epigenetic quartz vein hosted gold part of deposit.

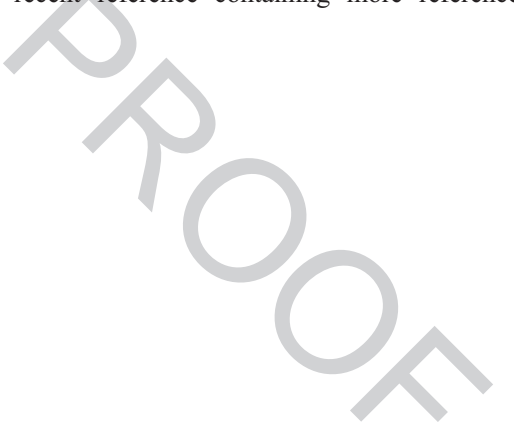




\subsubsection{Archaean greenstone belts}

799 Unlike many other Archaean areas, the greenstone 800 belts of the Fennoscandian Shield include only minor 801 occurrences of $\mathrm{Ni}-\mathrm{Cu}$ sulphides of which the disse802 minated Ni sulphide mineral deposits of Vaara and 803 Kauniinlampi (Halkoaho and Pietikäinen, 1999) in a 804 komatiitic cumulate of the Suomussalmi greenstone 805 belt are the most notable. The $\mathrm{Ni} / \mathrm{S}$ ratios are high and $806 \mathrm{Cu}$ tenors very low, similar to the Mt. Keith type of 807 komatiitic sulphides (Naldrett, 1989). The prospects 808 of Peura-aho and Hietaharju (Kurki and Papunen, 809 1985; Table 1) are composed of massive and disse810 minated $\mathrm{Ni}-\mathrm{Cu}$ sulphides at the contact zone between 811 a basal cumulate serpentinite lens of a komatiitic 812 basalt flow and underlying sulphide-bearing felsic 813 volcanic rock. The Arola and Sika-aho prospects 814 (Table 1) are tectonically remobilized Ni-sulphides 815 in shear zones, whereas the Tainiovaara deposit is 816 located in a small, intensely metamorphosed and 817 deformed ultramafic lens totally surrounded by 818 Archaean granitoids.

819 The geological environment and stratigraphic 820 sequences of the TKS greenstone complex (see 821 above) are quite similar to those of the Norseman822 Wiluna belt, Western Australia (Hill, 2001), although 823 the dimensions of the TKS belt are much smaller. 824 Thermal erosion of sulphidic substrates and channe825 lized ultramafic volcanic flows are considered prere826 quisites for the contamination and accumulation of 827 Ni-bearing sulphides in komatiites (Huppert et al., 828 1984; Lesher et al., 1984; Hill, 2001; Naldrett, 829 2001). In the Kuhmo belt, sulphide-bearing chert 830 layers that locally underlie the komatiitic flows and 831 cumulates in the lowermost komatiitic flow are 832 depleted in $\mathrm{Ni}$, indicating sulphide contamination 833 and segregation somewhere in the passage of the 834 flow (Papunen et al., 1998).

\section{4.1.2. Mafic layered intrusions}

836 The 2.5 to $2.4 \mathrm{Ga}$ period of igneous activity that 837 resulted in the emplacement of numerous layered 838 mafic-ultramafic intrusive complexes was important 839 in terms of major chromitite and $\mathrm{Ni}-\mathrm{Cu}-\mathrm{PGE}$ deposits. 840 According to Alapieti and Lahtinen (2002), approxi841 mately two dozen layered mafic intrusions and intru842 sion fragments are scattered within the Fennoscandian 843 Shield. One belt extends along the Archaean-Proter844 ozoic boundary and includes the Tornio-Kukkola intrusion at the Finnish-Swedish border, the Kemi and Penikat intrusions and scattered remnants of the wide Portio and Koillismaa complexes. Another belt trends in a SE direction through Finnish Lapland into Russia, and includes the Kaamajoki-Tsohkkoaivi, Koitelainen and Akanvaara intrusions in Finland and the Oulanka complex in Russia. The largest layered intrusion in the shield, the Burakovo intrusion in Russia, may be regarded as a continuation of this belt (Alapieti and Lahtinen, 2002). Several layered mafic intrusions also follow the margins of the PolmakPechenga-Imandra-Vazuga-Ust'Ponoy belt.

A number of the layered igneous complexes in Finland host $\mathrm{Ni}-\mathrm{Cu}$ and PGE occurrences. In NW Russia the intrusions, such as Mt. Generalskaya, Monchegorsk, Imandra, Feodor Tundra and Pana Tundra, are extensive and display high potential for $\mathrm{Ni}-\mathrm{Cu}$ and PGE deposits. Alapieti and Lahtinen (2002) classified the PGE occurrences into six categories: (1) disseminated base-metal sulphide-PGE deposits, (2) PGE-bearing offset deposits, (3) base-metal sulphidebearing PGE reefs, (4) sulphide-poor PGE reefs, (5) disseminated base-metal sulphide-PGE deposits associated with microgabbronorites and (6) PGE enrichments associated with "upper chromitites".

Reef type PGE deposits characterize, for example, the Penikat complex, where the megacyclic units were interpreted to be the result of replenishment of the magma in the crystallizing magma chamber, and the lower contacts of the units correlate with both sulphide-bearing and sulphide-poor PGE reefs. The disseminated base-metal sulphide-PGE deposits occupy the marginal part of the intrusion where the crystallization sequence is inverted and the rock is heterogeneous with abundant wall-rock fragments and breccia structures. The Kemi intrusion hosts a world-class chromite deposit (see Table 1). The deposit consists of stratiform, massive or semi-massive chromitite in the ultramafic basal cumulate of a layered igneous complex. The ore deposit is anomalously thick, up to $90 \mathrm{~m}$, and it extends subvertically to at least a depth of $500 \mathrm{~m}$. According to Alapieti et al. (1989), contamination of parental magma caused the crystallizing evolved melt to move to the primary liquidus field of chromite, and the dynamic conditions and tectonically-shaped form of the magma chamber accumulated chromite into a thick pile around the magma vent.
845

846

847

848

849

850

851

852

853

854

855

856

857

858

859

860

861

862

863

864

865

866

867

868

869

870

871

872

873

874

875

876

877

878

879

880

881

882

883

884

885

886

887

888

889

890

891

892 
893 4.1.3. $\mathrm{Ni}-\mathrm{Cu}$ deposits in Palaeoproterozoic

894 greenstone belts associated with rift-related

895 ultramafic volcanism

896 Rift-related subaerial to submarine volcanism, ran897 ging in composition from ultramafic to mafic and 898 intermediate, characterizes the Palaeoproterozoic 899 greenstone belts within the Karelian Craton. The 900 majority of the associated mineral deposits are iron 901 formations, but there is also a notable low-grade Ni$902 \mathrm{Cu}$ and PGE deposit related to the intrusion of the 9032.06 Ga Kevitsa layered igneous complex (cf. Fig. 2) 904 in Central Lapland (Mutanen, 1997). The best sections 905 of the disseminated mineralization are related to tec906 tonic remobilization, which upgraded the primary 907 igneous sulphides.

908 The Pechenga Ni-Cu deposits (Fig. 2) in NW 909 Russia are hosted by both ultramafic, weakly differ910 entiated ferropicritic flows and differentiated gabbro911 wehrlite intrusions within the 600 to $1000 \mathrm{~m}$ thickness 912 of the Pilgujärvi volcano-sedimentary formation 913 (Hanski, 1992; Melezhik, 1996). The mineralized 914 ultramafic bodies are structurally controlled by the 915 West Rift Graben and related palaeotectonic setting. 916 Two eruptive centres, Kaula and Kierdzhipori, have 917 been identified in the Pilgujärvi formation on the 918 western and eastern sides of the graben, respectively 919 (Melezhik et al., 1994). The ultramafic bodies are 920 further divided into the western, located higher up in 921 the stratigraphy, and eastern group. Green and Melez922 hik (1999) suggested that the western group is com923 posed of several flows, or portions of one flow, 924 interlayered with sediments, ferropicritic flows, and 925 tuffs, whereas the eastern group is composed of frac926 tionated gabbro-wehrlite sills emplaced close to the 927 base of the sedimentary sequence. According to Green 928 and Melezhik (1999), 226 differentiated ultramafic929 mafic bodies can be distinguished: 25 contain $\mathrm{Ni}-\mathrm{Cu}$ 930 deposits of economic interest, 68 are classified as 931 "Ni-Cu-bearing", and the remaining 113 are described 932 as "barren". There are four $\mathrm{Ni}-\mathrm{Cu}$ sulphide ore types: 933 massive ultramafic-hosted, brecciated, disseminated, 934 and "black shale"-hosted, and predominantly Cu-rich 935 stringer ores (Gorbunov et al., 1985). The ores, which 936 extend up to $400 \mathrm{~m}$ away from the gabbro-wehrlite 937 intrusions, are $\mathrm{Cu}$-rich, containing $2 \% \mathrm{Ni}$ and up to $93810 \% \mathrm{Cu}$. The ultramafic bodies of Souker, Raisoaivi, 939 Mirona, Kierddzhipori, Pilgujärvi and Onki in the 940 eastern group host disseminated and massive $\mathrm{Ni}-\mathrm{Cu}$ deposits in differentiated gabbro-wehrlite intrusions, and the Pilgujärvi intrusion is particularly voluminous (500 $\mathrm{m}$ thick, $6 \mathrm{~km}$ strike length) and well differentiated. The ultramafic mineralized ferropicritic flows of Semiletka, Kammikivi, Kotselvaara and Kaula of the western ore group are thin $(<100 \mathrm{~m})$ and contain all ore types (Green and Melezhik, 1999). Hanski (1992) and Melezhik (1996) consider that the host rocks of all the $\mathrm{Ni}-\mathrm{Cu}$ sulphide mineral deposits originated from the same ferropicritic parental magma (Fig. 3). This magma was derived from the stem of a mantle plume and erupted along a graben structure in the western ultramafic group as a flow on top of the sediments, whereas in the eastern group the magma intruded within a sedimentary pile where the magma cooled slowly and fractionated. Based on the sulphide textures and geochemistry, sulphur isotope studies (Hanski, 1992; Melezhik et al., 1994, 1998; Abzalov and Both, 1997), Re-Os isotope data (Walker et al., 1997) and PGE data (Abzalov and Both, 1997), Barnes et al. (2001) modelled the formation of ores and concluded that the ferropicritic magma reached sulphide saturation prior to ore formation. Sulphur was derived from the unconsolidated sediments and reacted with the ultramafic flow, collected metals and accumulated sulphide melt in structural traps where sulphides were fractionated and separated Mss-rich crystals from $\mathrm{Cu}$-rich residual melt. Finally the breccia sulphides formed during deformation.

\subsection{4. $\mathrm{Ni}-\mathrm{Cu}$ deposits in Svecofennian orogenic mafic-ultramafic intrusions}

A number of mafic-ultramafic intrusions were emplaced during the Svecofennian Orogeny at 1.89 to $1.87 \mathrm{Ga}$. Peltonen (2005) divides them into three Groups (I, II and III), of which the Group I intrusions, derived from hydrous arc-type tholeiitic basalts, were emplaced close to the peak of the Svecofennian Orogeny (at $\sim 1.89 \mathrm{Ga}$ ). Group II intrusions are large synvolcanic layered gabbro complexes in the southern Finland arc complex and represent low-pressure crystallization products of relatively juvenile subalkalic tholeiitic basalts, within an oceanic arc. These intrusions have low potential for Ni deposits. Group III intrusions include Ti-Fe-P-rich anorogenic gabbros within the central Finland granitoid region, and host a few Ti-P deposits.
941

942

943

944

945

946

947

948

949

950

951

952

953

954

955

956

957

958

959

960

961

962

963

964

965

966

967

968

969

970

971

972

973

974

975

976

977

978

979

980

981

982

983

984

985

986

987 


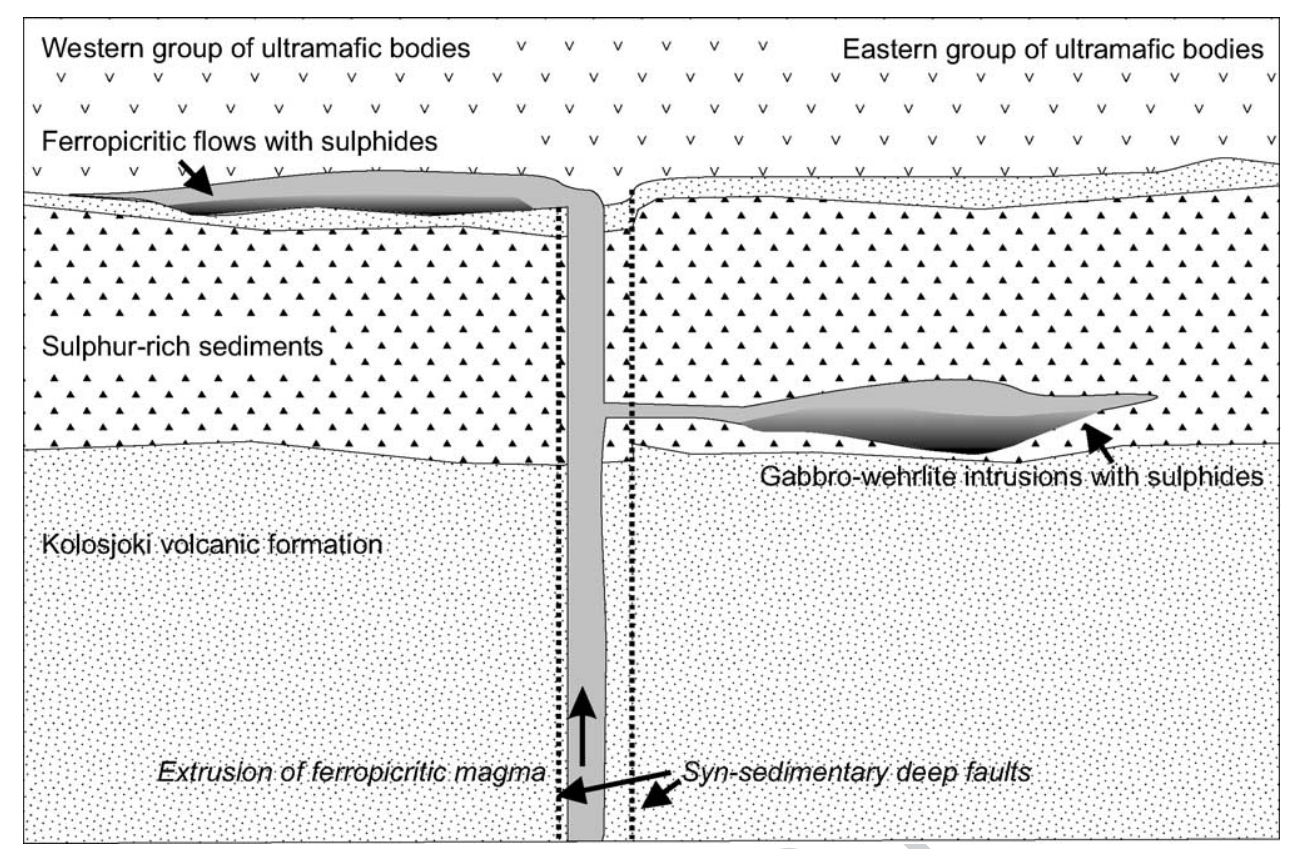

Fig. 3. Depositional model of the formation of the Pechenga Ni-Cu deposits after Melezhik (1996) and Barnes et al. (2001).

988 The Group I intrusions host several magmatic Ni$989 \mathrm{Cu}$ sulphide occurrences, and nine of them have been 990 mined in central Finland since the 1960 s, producing a 991 total of $0.28 \mathrm{Mt}$ of contained nickel metal and $0.1 \mathrm{Mt}$ 992 copper (Papunen, 1989, 2003; Puustinen et al., 1995). 993 This group is described below in more detail.

994 There are three main nickel ore belts in the Sveco995 fennian area (Papunen and Gorbunov, 1985), which 996 can be further divided into several subzones (Puusti997 nen et al., 1995). Two of the belts, the Kotalahti belt 998 and the Vammala belt, are located in central Finland, 999 whereas the Lappvattnet belt is located in northern 1000 Sweden. The Kotalahti belt roughly parallels the 1001 Archaean-Proterozoic boundary and is hosted by 1002 sedimentary-volcanic formations between the Keitele 1003 microcontinent and the Archaean craton, whereas the 1004 Vammala belt parallels the Tampere schist belt along 1005 the southern margin of the Keitele microcontinent 1006 against the Bergslagen microcontinent (see Section 5 1007 below). The Lappvattnet belt is situated along the 1008 southern margin of the Knaften area against the Both1009 nia microcontinent in Sweden (Fig. 1). Intensely 1010 deformed metasediments with black schist interlayers 1011 characterize the environment of the intrusions and the 1012 wall-rocks are commonly migmatized to neosome- rich schollen migmatites. The neosome intersects the intrusions as random granitic vein networks. The felsic veins metasomatized the ultramafic olivinebearing parts of the intrusions, forming zoned margins composed of talc, tremolite, and chlorite against the phlogopite-bearing vein fill (Papunen, 1971; Marshall et al., 1995; see also Menard et al., 1999). The zoned margins were not developed around the veins in pyroxenitic and gabbroic parts of the intrusions. Structural analysis implies that the intrusion of mafic magma took place before or at the peak of $\mathrm{D}_{2}$ deformation and the intrusions were deformed and brecciated during late $F_{2}$ folding (Kilpeläinen, 1998). The contact zones against felsic migmatites experienced metasomatic alteration and peridotites were altered to serpentinites and pyroxenites to amphibole-chlorite rocks. In the Vammala belt the metamorphic conditions reached upper amphibolite to lower granulite facies (i.e., 600 to $700{ }^{\circ} \mathrm{C}$ and 5 to $6 \mathrm{kbar}$; Peltonen, 1990) and the cooling from peak conditions was slow, as evident from the subsolidus re-equilibration of olivine and chromite spinel and redistribution of $\mathrm{Ca}$ between pyroxenes (Peltonen, 1995b).

Two main types of Group I mafic-ultramafic intrusions host $\mathrm{Ni}-\mathrm{Cu}$ sulphides: a) differentiated perido- 
1038 tite-gabbro \pm diorite bodies (e.g., Kotalahti, Laukun1039 kangas and Telkkälä) and b) weakly differentiated 1040 ultramafic olivine-dominated cumulate bodies (e.g., 1041 Vammala; Fig. 4, Kylmäkoski, and Hitura; Mäkinen, 1042 1987). The Group Ia intrusions are situated at the 1043 craton margin in the eastern part of the Kotalahti 1044 belt. $\mathrm{Ni}-\mathrm{Cu}$ deposits hosted by differentiated intru1045 sions have been mined in Kotalahti, Laukunkangas, 1046 Hälvälä, and Tekkälä in SE Finland (Fig. 5; Papunen 1047 and Vorma, 1985), of which Kotalahti is the largest 1048 deposit that has been mined so far (see Table 1). The 1049 host intrusions vary in shape, size and composition, 1050 and the rock suite ranges from peridotites to diorites 1051 (Makkonen, 1996; Papunen, 2003). In Kotalahti (Fig. 1052 5) and Telkkälä the most ultramafic members are 1053 located in the central parts of the intrusive bodies, 1054 but in Laukunkangas the ultramafic rock is located at 1055 the base of the predominantly mafic body. Locally, 1056 gabbroic and dioritic members of the differentiation 1057 series display anomalously low Ni content of mafic 1058 silicates.

1059 Olivine is the earliest cumulus mineral in all miner1060 alized Group Ia intrusions, followed by orthopyroxene 1061 and plagioclase. Chromite is rare or totally absent, but 1062 primary magmatic amphiboles are common intercu1063 mulus minerals. In gabbroic intrusions orthopyroxene 1064 is the dominant cumulus phase, followed by plagio1065 clase. Sulphides are of disseminated and breccia type, 1066 partly outside the intrusion as offset orebodies. The 1067 parental magmas of the Ia intrusions were tholeiitic 1068 basalts, with $\mathrm{MgO}$ contents ranging from $8 \%$ to $11 \%$ 1069 and an $\mathrm{Al}_{2} \mathrm{O}_{3} / \mathrm{TiO}_{2}$ ratio of around 10 (Makkonen, 1070 1996). Their concentrations of compatible elements, 1071 notably Ni, are relatively high, but the PGE contents 1072 are low (Papunen, 1989). Evidence for contamination 1073 includes elevated LREE and $\mathrm{Zr}$ and low average $1074 \varepsilon_{\mathrm{Nd}}^{(1.9 \mathrm{Ga})}$ value, +0.7 (Makkonen, 1996).

1075 The Group $\mathrm{Ib}$ intrusions and related Ni-Cu depos1076 its are situated in the Vammala belt, although the 1077 Group Ia intrusions also occur in the western exten1078 sion of the belt (e.g., Hyvelä). Group Ib intrusions 1079 also characterize the Lappvattnet belt and the Hitura 1080 area. The rock types range from dunites to wehrlites 1081 and early-crystallized chromian spinel is a common 1082 accessory mineral. Early crystallization of clinopyrox1083 ene and lack of cumulus plagioclase in Group Ib are 1084 the main distinctive features. The sulphides are mainly 1085 of disseminated type and accumulated at the basal contact zones of primary olivine \pm clinopyroxene cumulates (Fig. 4). The average $\varepsilon_{\mathrm{Nd}}^{(1.9 \mathrm{Ga})}$ value of the type $\mathrm{Ib}$ intrusions in the Vammala belt is +1.7 , which is lower than the corresponding value of +2.7 obtained from the mafic intrusions and extrusions of the Group II intrusions south of the Vammala belt (Peltonen, 2005).

The geodynamic setting of orogenic $\mathrm{Ni}-\mathrm{Cu}$ deposits at convergent boundaries of microplates is greatly obscured by severe tectonic deformation, metamorphism and metasomatic overprints. Gaál (1972, 1985) and Puustinen et al. (1995) inferred that the Group Ia intrusions were emplaced into a subvertical $D_{3}$ wrench lineament, which is clearly visible along the Kotalahti belt in tectonic and geophysical maps. However, in detail most of the intrusions occur outside the shear zone and a genetic relationship is ambiguous. According to Peltonen (2005), the plutonism occurred over a wide zone due to westward subduction during the final stages of the closure of the basin between the primitive arc complex and the Archaean craton. Synchronous transtensional shear systems, developed at the continental margin, facilitated the ascent of melts locally along subvertical shear zones. During $\mathrm{D}_{3}$ the zones were reactivated and the intrusions were deformed and brecciated. Early assimilation of felsic sedimentary material and related increase of silica in the ascending magma resulted in the crystallization sequence olivine-orthopyroxene-plagioclase typical of type Ia intrusions (Haughton et al., 1974). Accordingly, low $\varepsilon_{\mathrm{Nd}}^{(\mathrm{T})}$ values and elevated LREE and $\mathrm{Zr}$ abundances indicate contamination (Makkonen, 1996). The primary parental magma was sulphide unsaturated and the concentrations of chalcophile elements, notably $\mathrm{Ni}$, were high. Contamination with sulphide-bearing sediments turned the magma to sulphide saturation and accumulation of sulphides took place. Mutually intrusive breccias between the members of the differentiation series, lack of compositional layering, breccia type sulphides also as offset orebodies outside the intrusion proper, and complicated shapes of the intrusive complexes are all evidence of polyphase intrusion, where the melt fractionated intermittently in a magma chamber before final emplacement (Papunen, 2003). Syn-magmatic deformation squeezed the melt and early-crystallized silicates from high stress to low stress areas. At this stage the evolved, depleted and barren melt from the
1086

1087

1088

1089

1090

1091

1092

1093

1094

1095

1096

1097

1098

1099

1100

1101

1102

1103

1104

1105

1106

1107

1108

1109

1110

1111

1112

1113

1114

1115

1116

1117

1118

1119

1120

1121

1122

1123

1124

1125

1126

1127

1128

1129

1130

1131

1132

1133 


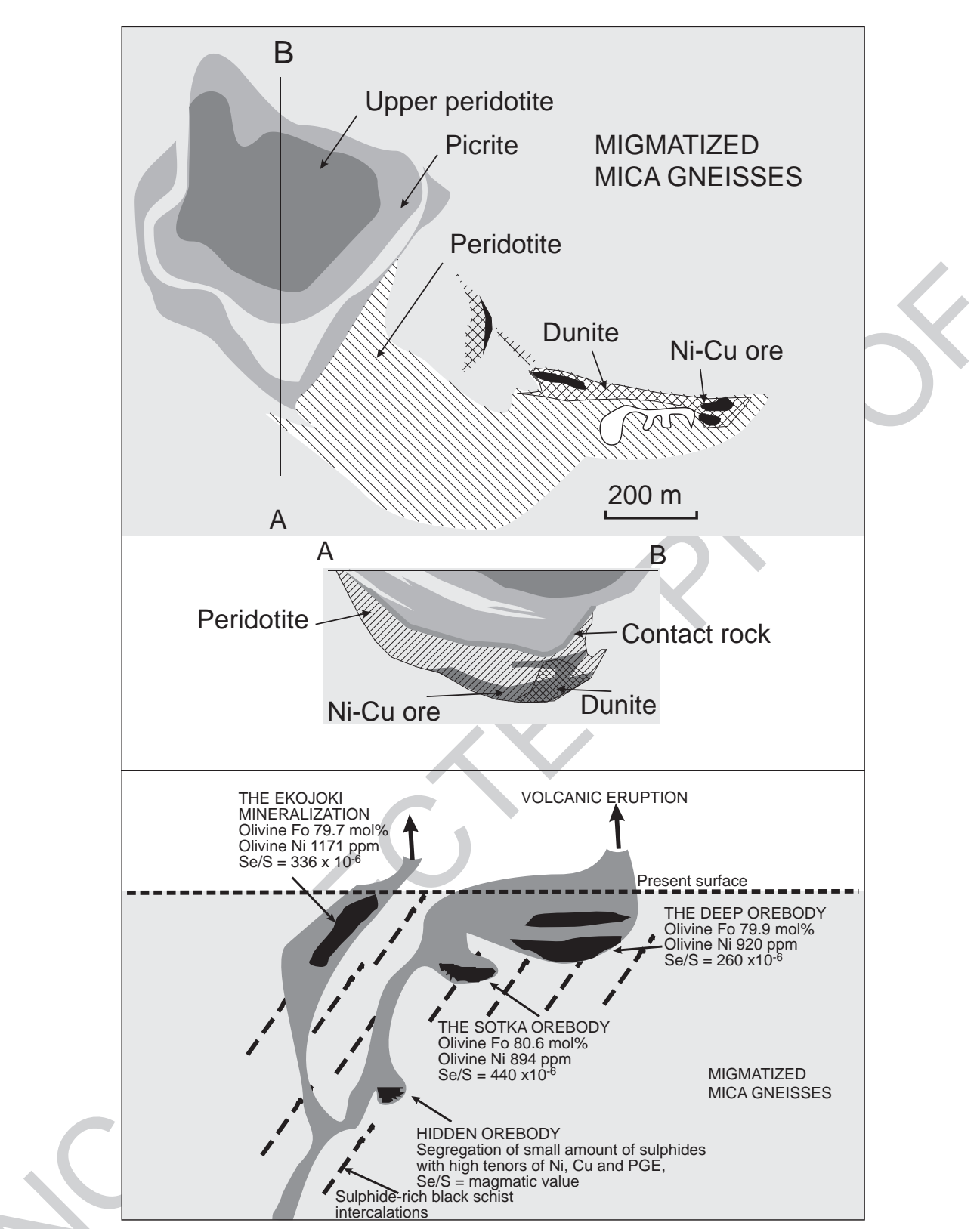

Fig. 4. The Vammala Ni-Cu deposit: the host rock of the Vammala Ni-Cu deposit is the Stormi ultramafic intrusion, which has the shape of a shallow bowl with mineralized dunitic portions at the base. Upper part of the intrusion consists of picrite and "upper peridotite", which are barren and geochemically different from the mineralized lower dunite-peridotite intrusion. The picritic portion represents an ultramafic volcanic formation, which belongs to the supracrustal sequence and pre-dates the intrusion of the fertile dunite-peridotite body. The wall-rocks are migmatized mica gneisses, which also exist as inclusions and tongues inside the picritic layer and locally also between the lower peridotite and picrite. The whole ultramafic body is metamorphosed and intersected by felsic pegmatite dykes. The deposit was mined between 1973 and 1995 and produced $7.4 \mathrm{Mt}$ ore at $0.69 \% \mathrm{Ni}$ and $0.4 \% \mathrm{Cu}$. The Vammala genetic model: according to Peltonen (1995a) the Vammala-type intrusions are feeder channels of basaltic lava flows. The magma became contaminated by wall-rock sulphides and accumulated disseminated and semimassive sulphides together with early crystallized olivine, spinel and pyroxenes in suitable parts of the intrusion channel. Composition of olivine can be used to follow the evolution of magma in the feeder channel. 
1134 upper part of the magma chamber separated and 1135 formed $\mathrm{Ni}$-depleted regions of the intrusive complex. 1136 In the final phase, the sulphide-bearing ultramafic 1137 cumulates and magma from the lower part of chamber 1138 intruded to form mineralized ultramafic bodies. 1139 Finally the accumulated massive sulphides were 1140 squeezed out from the deeper parts of the magma 1141 chamber and deposited breccia offset orebodies in a 1142 zone of tectonic weakness.

1143 Peltonen (2005) considers that the Group Ib ultra1144 mafic cumulate bodies represent former feeder chan1145 nels for mafic shallow intrusions, sills or volcanic 1146 eruptions (Fig. 4). Calculations based on the composi1147 tion of the most magnesian olivine in the intrusions 1148 and $\mathrm{Fe} / \mathrm{Mg}$ distribution between olivine and melt 1149 indicate that the $\mathrm{MgO}$ contents of the parental mag1150 mas ranged from $8 \%$ up to $12 \% \mathrm{MgO}$. Common 1151 magmatic intercumulus amphibole suggests a hydrous 1152 parental magma indicative of arc-type basalt. Accord1153 ingly, the mass calculations based on the high $\mathrm{Mg}$ 1154 content of cumulates compared to the composition of 1155 parental magma suggest that the ultramafic cumulates 1156 visible at the present erosion level represent only a 1157 minor portion of the total igneous complex from 1158 which the upper part was eroded away (Peltonen, 1159 1995a). Trace element composition, low Se/S in sul1160 phides, lower than mantle $\varepsilon_{\mathrm{Nd}}^{(1.9 \mathrm{Ga})}$ values, and com1161 mon graphite in ultramafic cumulates show that the 1162 trace element composition of the parental magma for 1163 the Group Ib intrusions was strongly modified during 1164 emplacement through the crust. The mantle-derived 1165 magma was sulphide unsaturated, but became satu1166 rated at the level of crust due to interaction with 1167 sulphur derived from the black schists (Peltonen, 1168 1995a). The sulphides accumulated at suitable traps 1169 in feeder channels together with early crystallizing 1170 olivine and spinel.

1171 The differences between Group Ia and Ib intrusions 1172 are due to the more profound contamination of Group 1173 Ia intrusions, their fractionation in an intermittent 1174 magma chamber, and intrusion as fractionated batches 1175 to their present positions in the crust. The Group Ib 1176 intrusions represent feeder channels of a more open 1177 intrusive-volcanic system, and probably also a more 1178 voluminous intrusion of magma into an environment 1179 where the crustal contaminant was slightly different 1180 and the tectonic evolution more tranquil than for 1181 Group Ia intrusions.

\subsection{VMS deposits}

1182

Volcanogenic massive sulphide (VMS) deposits are the ore type that is currently the most exploited in the Fennoscandian Shield. Five deposits are currently mined in the Skellefte district in northern Sweden, one deposit in the Pyhäsalmi area in central Finland and two deposits in the Bergslagen region of southcentral Sweden. However, it is unclear whether or not some of the major deposits in the Bergslagen region should be classified as VMS deposits (e.g., Garpenberg and Zinkgruvan), see below. Also an open question is whether or not the Outokumpu deposits (Kontinen, 1998; Sorjonen-Ward et al., 2004), although discussed in this section, really are VMS deposits sensu stricto.

\subsubsection{Geodynamic setting}

Significant VMS deposits (Table 1) are associated exclusively with Palaeoproterozoic volcanic arc terranes in the Fennoscandian Shield (Box 8-1, Weihed and Eilu, 2005, this volume). With recent improvements in radiogenic dating techniques it has been shown that the host volcanic arcs have different ages and were accreted to the old Karelian craton at different stages during the evolution of the Svecokarelian orogen, between ca. 1.95 and $1.85 \mathrm{Ga}$. The earliest expressions of Svecokarelian accretionary processes are the Jormua, Outokumpu, and possibly Nuttio ophiolitic sequences, which formed at ca. 1.97 Ga and were emplaced onto the Karelian Craton between 1.94 and $1.89 \mathrm{Ga}$.

The 1.93 to 1.92 Ga Pyhäsalmi arc was the next to be accreted and contains Kuroko-style VMS deposits, as does the Skellefte volcanic arc that formed 20 to 30 million years later than the Pyhäsalmi arc. The Bergslagen-Uusimaa belt in south-central Sweden and southern Finland contains VMS deposits of a more continental arc affinity that formed roughly at the same time as the Skellefte deposits.

The Palaeoproterozoic arc assemblages also seem in detail to represent slightly different tectonic settings, apart from their age differences (Fig. 6). The Pyhäsalmi bimodal volcanic rocks formed during rifting of a Palaeoproterozoic oceanic island arc, whereas the younger Skellefte volcanic rocks were formed during extension of an immature continental volcanic arc. The Bergslagen province formed by volcanism in
1183 


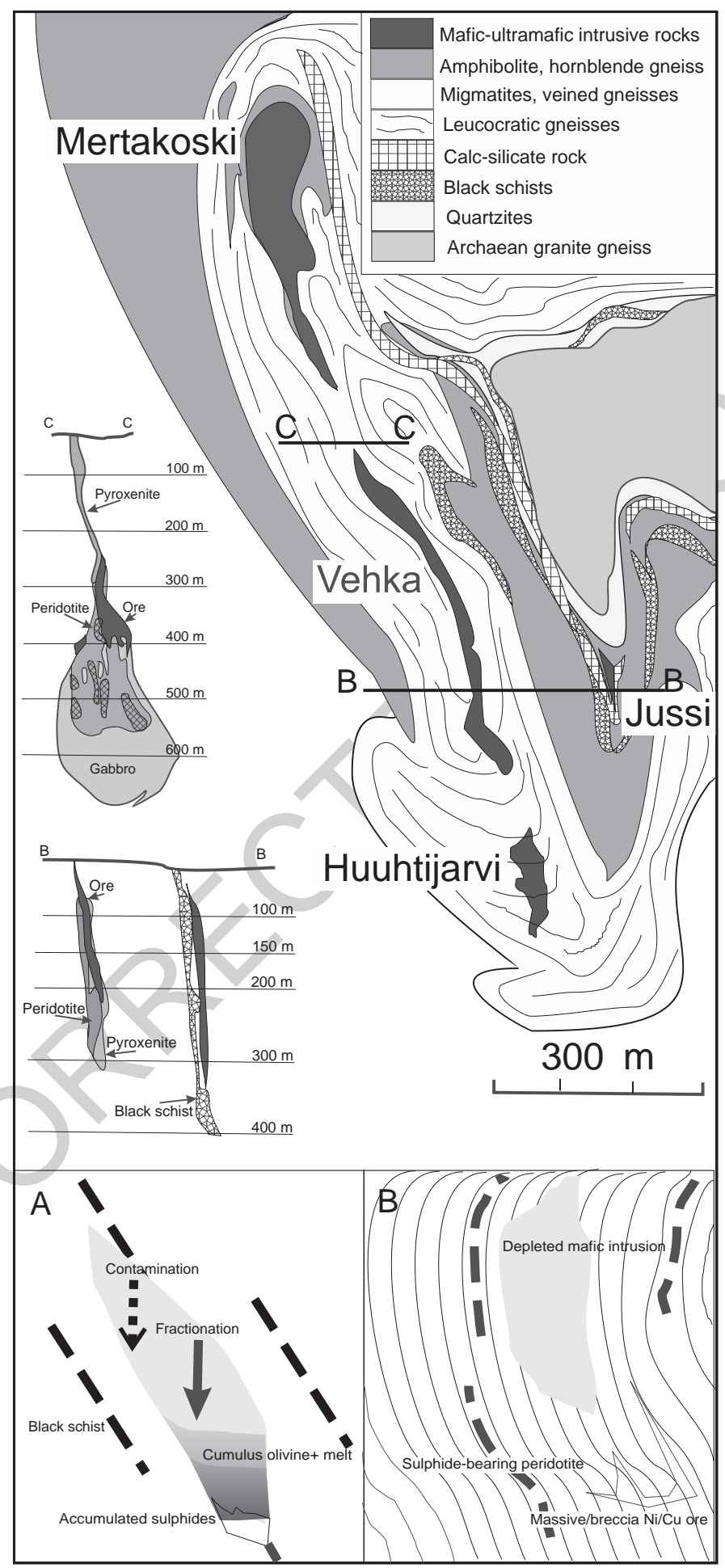


1228 a continental margin setting and is fundamentally 1229 different in the composition of its host rocks and 1230 associated metallogeny compared to the Pyhäsalmi 1231 and Skellefte provinces. The Vihanti-Pyhäsalmi and 1232 Skellefte deposits show many similarities with Kur1233 oko-type deposits, whereas the Outokumpu deposits 1234 have been described as "Cyprus-type" deposits (Helo1235 vuori, 1979; Ekdahl, 1993; Allen et al., 1996a). 1236 Recently, however, the idea of exhalative ore forma1237 tion for the Outokumpu deposits has been questioned, 1238 as the chemical composition of the host rocks indi1239 cates that they are subcontinental lithospheric mantle 1240 rocks (Kontinen, 1998; Sorjonen-Ward et al., 2004). 1241 Sorjonen-Ward et al. (2004) propose that mineraliza1242 tion instead may represent deep levels of subseafloor 1243 hydrothermal convection.

1244 The apparent restriction of Palaeoproterozoic VMS 1245 mineralization to the Fennoscandian Shield is some1246 what enigmatic. The deposits of the Fennoscandian 1247 Shield have ages that are similar, within error, to those 1248 of the Trans-Hudson and Penokean orogenies in North 1249 America (e.g., in the Flin-Flon and Snow Lake areas) 1250 and share many other features with these deposits (see 1251 Syme et al., 1982). The scarcity of known VMS 1252 mineralization in the Archaean of the Fennoscandian 1253 Shield can be attributed to two factors: (1) the lack of 1254 suitable host sequences of the appropriate age, as 1255 explained above, and (2) the unexplored nature of 1256 the Archaean areas, especially in Russia.

\section{4.2.2. Timing and relation to regional tectonic}

\section{8 evolution of the shield}

1259 The Pyhäsalmi area is characterized by bimodal 1260 volcanic sequences. The mafic volcanic rocks are low$1261 \mathrm{~K}$, island-arc tholeiite metabasalts and basaltic meta1262 andesites, whereas the felsic volcanic rocks include 1263 low-K, transitional to calc-alkaline rhyodacites, rhyo- lites, and high-silica rhyolites (Rasilainen, 1991; Kousa et al., 1994; Lahtinen, 1994). The local basement to the bimodal volcanic sequence is suggested to comprise a collage of ca. 2.0 to $1.94 \mathrm{Ga}$ volcanic rocks (Lahtinen, 1994). Within the bimodal volcanic sequence, massive sulphide deposits occur either at the transition from mafic to felsic volcanic rocks, or are entirely hosted by felsic pyroclastic rocks (Huhtala, 1979; Mäki, 1986; Rasilainen, 1991). Deformed 1.93 to $1.91 \mathrm{Ga}$ tonalites and trondhjemites are spatially associated with ore-associated bimodal volcanic sequences (Lahtinen, 1994). Isotope and trace element data from these rocks show that they were produced by partial melting of ca. 2.0 Ga primitive island-arc tholeiite basalts (Lahtinen, 1994; Lahtinen and Huhma, 1997). The intrusive rocks are geochemically similar to and of the same age as the ore-associated metarhyolites, and are therefore considered to represent subvolcanic equivalents of the latter (Kousa et al., 1994; Lahtinen, 1994).

In places, the bimodal volcanic sequence is overlain by migmatitic metasedimentary rocks with intercalated calc-silicate and graphite-bearing interlayers. In turn, this sequence is succeeded by a younger $(\sim 1.88 \mathrm{Ga})$ calc-alkaline volcanic suite formed in a mature arc setting (Kousa et al., 1994).

According to Lahtinen (1994), the 1.93 to $1.91 \mathrm{Ga}$ volcanic rocks that host $\mathrm{Zn}-\mathrm{Cu}$ deposits in the Vihanti-Pyhäsalmi district formed within a rifted primitive island arc. Intra-arc rifting in a juvenile setting is implied by the occurrence of bimodal volcanism, low-K tholeiitic basalts, and minimal hornblende fractionation in the generation of rhyolites. The felsic subvolcanic intrusions have juvenile $\varepsilon_{\mathrm{Nd}}$ values, indicating an origin by partial melting of a primitive low$\mathrm{K}$ island-arc basalt source (Kousa et al., 1994; Lahtinen, 1994).

\footnotetext{
Fig. 5. Kotalahti: this is an example of fractionated intrusions, which host $\mathrm{Ni-Cu}$ deposits in the Svecofennian area of Finland. The main rock types are peridotite and pyroxenite in the upper part of the subvertical, plate-shaped intrusion and in the southern Huuhtijärvi vertical pipeshaped body, but gabbros abound in the deep part of the Vehka body. Contacts between different rock types are commonly sharp or gradual over a short distance. The disseminated and breccia ores occur mainly in peridotites and pyroxenites, and gabbros in the deeper part of the intrusion, in particular, are barren and even depleted in nickel. The intrusion is metamorphosed and intersected by felsic dykes. The massive Jussi orebody with high-grade $\mathrm{Ni}-\mathrm{Cu}$ sulphides exists about $150 \mathrm{~m}$ east of the intrusion as a vertical slab in black schist and calc-silicate rock environment. The mine produced $13 \mathrm{Mt}$ of ore at $0.7 \% \mathrm{Ni}$ and $0.27 \% \mathrm{Cu}$. The Kotalahti model: the model of the Kotalahti-type deposits is based on early contamination of mantle-derived melt by sedimentary sulphides and felsic country rocks, which caused sulphide immiscibility and fractionation in a magma chamber where the upper part became depleted in chalcophile elements and sulphides and mafic crystals accumulated at the lower part of the chamber (A). In subsequent orogenic deformation the different parts of the fractionated chamber remobilized and intruded separately to form depleted mafic and intermediate intrusions and sulphide-bearing peridotite and pyroxenite bodies. Sulphides remobilized with the ultramafic portion and could also be intruded as offset ores outside the intrusion proper (B).
} 
A

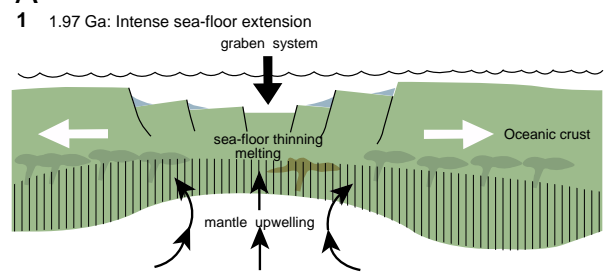

2 VMS $=1-2$ million years after 1 ) Fissure-fed basalts, "Cyprus type" VMS

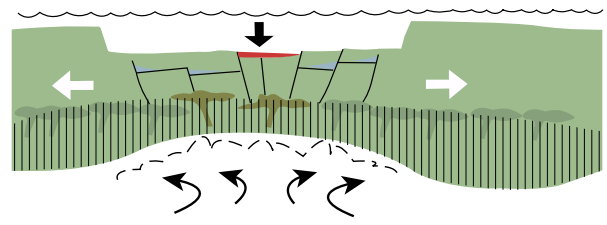

3 c. 1.93 Ga Post-extension: basin inversion (compression), convergence

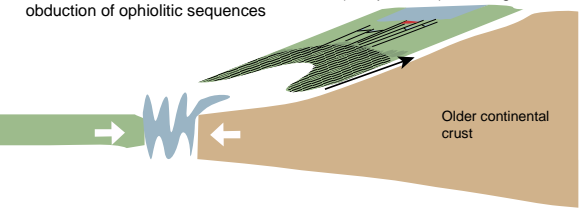

C

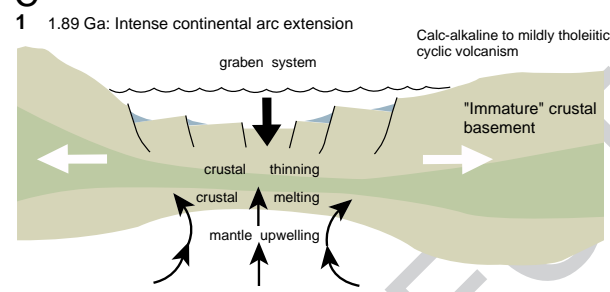

$2 \mathrm{VMS}=1-2$ million years after 1 ) Near synchronous evolution of rhyolite volcanoes to "VMS stage" Fissure-fed basalts

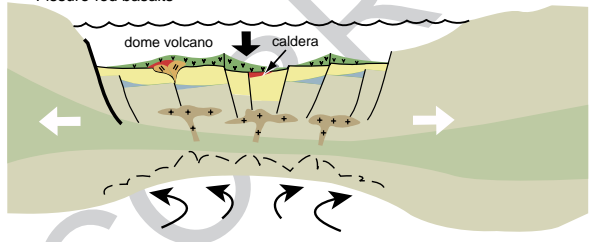

3 c. $<1.87$ Ga: sedimentary and volcanic successions c. $<1.87$ Ga: sedimentary and volca
and basin inversion (compression)
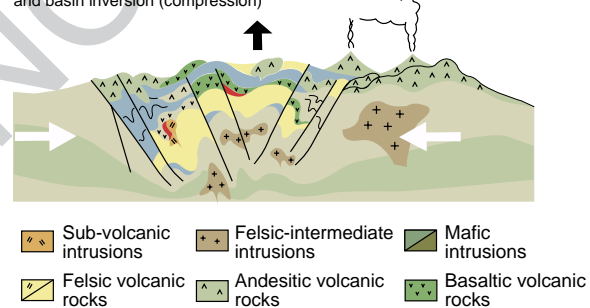

B

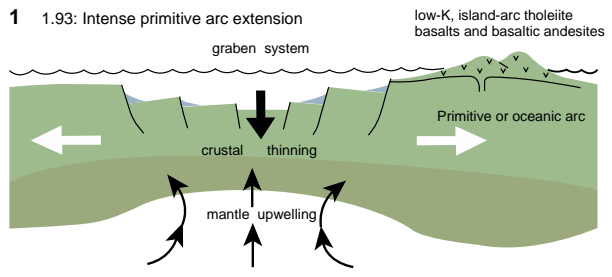

2 VMS $=1-2$ million years after 1 )

Near synchronous evolution of high silica rhyolite volcanoes to "VMS stage" Fissure-fed basalts

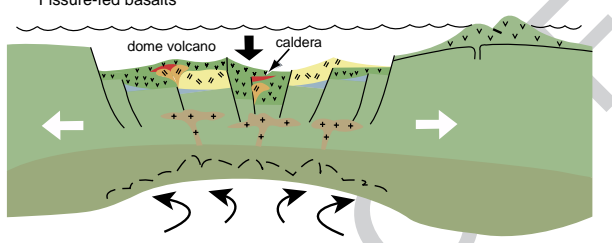

3 c. 1.90 Ga: sedimentary and volcanic successions and basin inversion (compression)

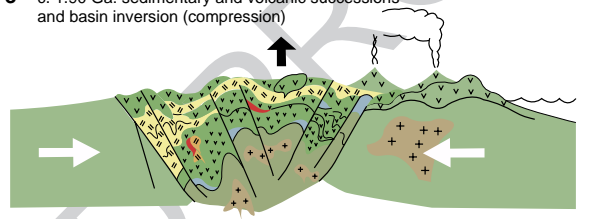

D

11.89 Ga: Intense intra-crustal extension

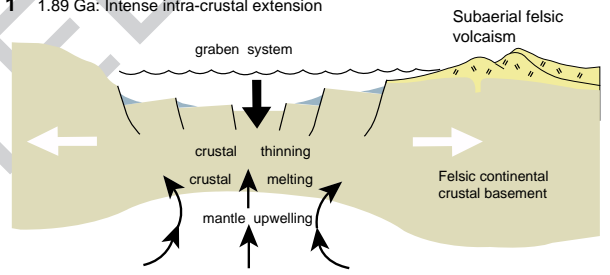

2 VMS $=1-2$ million years after 1 ) Near synchronous evolution of rhyolite calderas to "VMS stage" $\left\{\begin{array}{l}\text { Subaerial felsic } \\ \text { volcaism }\end{array}\right.$

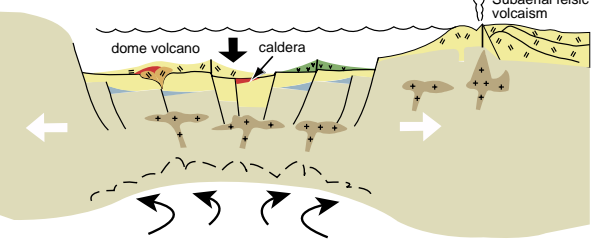
3 c. 1.87 Ga: sedimentary and volcanic successions
and basin inversion (compression)

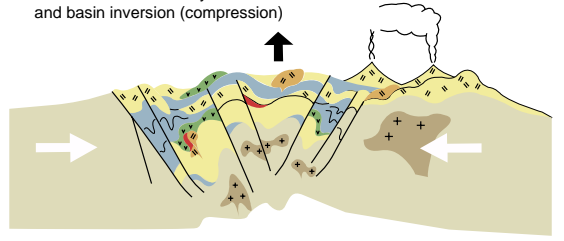

Massive sulphide ore

Sedimentary

Fig. 6. Key geodynamic features of VMS deposits. Model adapted from Allen et al. (2002). Tectonic setting during formation of (A) ophiolitic VMS deposits (Outokumpu type), (B) primitive arc VMS deposits (Vihanti-Pyhäsalmi type), (C) mature arc or continental margin VMS deposits (Skellefte type) and (D) intracontinental VMS deposits (Bergslagen type). 
1301 Roberts (2002) suggested that the basalts and rhyo1302 lites in the immediate host sequence to these deposits 1303 did not form in a proto-arc setting. Instead, Roberts 1304 (2002) interprets the district as a rifted primitive vol1305 canic arc. Roberts (2002) also suggests that an asso1306 ciation with tholeiitic basalts and transitional to calc1307 alkalic rhyolites, including high-silica varieties, 1308 broadly fits within the "bimodal mafic type" classifi1309 cation of Barrie and Hannington (1999) and argues 1310 that the association of $\mathrm{Zn}-\mathrm{Cu}$ mineralization within a 1311 relatively mature arc assemblage is analogous to the 1312 observations of Bailes and Galley (1999) in the Flin1313 Flon Belt, Canada, where Zn-dominant deposits occur 1314 within mature arc assemblages, and most $\mathrm{Cu}$-domi1315 nant deposits occur within primitive arc assemblages. 1316 The Skellefte district is a $120 \times 30 \mathrm{~km}$ Palaeopro1317 terozoic volcanic-dominated belt that contains over 80 1318 massive sulphide deposits (Rickard, 1986; Weihed et 1319 al., 1992; Allen et al., 1996b). The volcanic stratigra1320 phy is composed of calc-alkaline basalt-andesite1321 dacite-rhyolite, tholeiitic basalt-andesite-dacite, 1322 high-Mg (komatiitic) basalt and subordinate sedimen1323 tary rocks, and is intruded by syn- and post-volcanic 1324 granitoids (Vivallo and Claesson, 1987; Allen et al., 1325 1996b, 2002). About half the volcanic rocks are rhyo1326 lites. Primitive isotopic signatures suggest that mag1327 mas were mainly mantle-derived (Billström and 1328 Weihed, 1996). The stratigraphy is very complex, 1329 laterally variable, and diachronous, and marker hor1330 izons are rare. On a regional scale, however, a lower $1331>3 \mathrm{~km}$ thick, ore bearing, marine volcanic complex $1332(\sim 1.90$ to $1.88 \mathrm{Ga})$ is overlain by a $>4 \mathrm{~km}$ thick, 1333 mixed sedimentary and volcanic sequence. According 1334 to Allen et al. (2002), the dominance of marine 1335 depositional environments throughout the lower vol1336 canic complex indicates strong extension and subsi1337 dence. The overlying mixed sedimentary and volcanic 1338 sequence records rapid uplift, erosion and renewed 1339 rifting, and includes medial-distal facies of volumi1340 nous, ca. 1.88 to $1.87 \mathrm{Ga}$, subaerial felsic magmatism. 1341 Allen et al. (2002) point out that the stratigraphic 1342 architecture, range of volcanic compositions and 1343 abundance of rhyolites indicate that the district is a 1344 remnant of a strongly extensional intra-arc region that 1345 developed on continental or mature arc crust in con1346 trast to the primitive volcanic arc setting for the 1347 Vihanti-Pyhäsalmi belt. Most VMS ores occur in 1348 near-vent facies associations at the top of local volca- nic cycles, especially rhyolitic dome-tuff cone volcanoes (Allen et al., 1996b). Regionally, these VMS ores occur on at least two stratigraphic levels, most commonly near the upper contact of the lower volcanic complex.

The Bergslagen district, located in south-central Sweden, and the extension into SW Finland, the Uusimaa belt, are 1.90 to $1.87 \mathrm{Ga}$ in age and characterized as a felsic magmatic region. The volcanic succession is $1.5 \mathrm{~km}$ thick and overlies turbiditic metasediments in the east, and is over $7 \mathrm{~km}$ thick with no exposed base in the west (Lundström, 1987; Allen et al., 1996a). The basement is interpreted to be older, unexposed, continental crust.

In contrast to the Vihanti-Pyhäsalmi and Skellefte districts, Bergslagen contains a diverse range of ore deposits, including banded iron formations, magnetite skarns, manganiferous skarns and marble-hosted iron ores, apatite-magnetite iron ores, stratiform and stratabound $\mathrm{Zn}-\mathrm{Pb}-\mathrm{Ag}-(\mathrm{Cu}-\mathrm{Au})$ sulphide ores, and $\mathrm{W}$ skarns (Hedström et al., 1989; Sundblad, 1994; Allen et al., 1996b).

Although traditionally described as massive sulphide ores divided into the Åmmeberg and Falun types (Sundblad, 1994), and historically among the first ore deposits in Sweden described as exhalative (Koark, 1962), their classification as typical VMS deposits can be questioned. The ore deposits conform, with some exceptions, to a regional ore stratigraphy. Based on physical characteristics, the main base-metal deposits span a range between two end-member types (Allen et al., 1996b). The first type comprises sheetlike, bedded, stratiform $\mathrm{Zn}-\mathrm{Pb}-\mathrm{Ag}$-rich, $\mathrm{Fe}$ and $\mathrm{Cu}$ sulphide-poor deposits such as Zinkgruvan. These deposits are hosted by rhyolitic ash-siltstones with marble, skarn, and siliceous chemical sediment beds, and have intense footwall potassic alteration, silicification, and subordinate Mg-rich alteration (Hedström et al., 1989). Allen et al. (1996b) named these deposit "stratiform ash siltstone"-hosted $\mathrm{Zn}-\mathrm{Pb}-\mathrm{Ag}$ sulphide deposits (SAS type) and included some deposits of the Åmmeberg type (see Sundblad, 1994 and references therein). The second end-member type according to Allen et al. (1996b) includes irregular multi-lens and pod-like, strata-bound, massive and disseminated $\mathrm{Zn}$ $\mathrm{Pb}-\mathrm{Ag}-\mathrm{Cu}$ mineralization such as Garpenberg, and more massive pyritic $\mathrm{Cu}-\mathrm{Zn}-\mathrm{Pb}-\mathrm{Ag}-\mathrm{Au}$ mineralization such as Falun. These deposits straddle marble 
1397 beds within felsic metavolcanic rocks, are closely 1398 associated with Mg-rich tremolite-diopside skarn 1399 and dolomite zones within the marbles, and have 1400 intense footwall Mg-rich alteration (phlogopite1401 biotite-talc-almandine-cordierite-amphibole-quartz 1402 schists). These deposits are designated "strata-bound", 1403 volcanic-associated, limestone-skarn $\mathrm{Zn}-\mathrm{Pb}-\mathrm{Ag}-\mathrm{Cu}-$ $1404 \mathrm{Au}$ sulphide deposits, SVALS type, by Allen et al. 1405 (1996b) and correspond approximately to the Falun 1406 type (see Sundblad, 1994 and references therein). 1407 Allen et al. (1996b) suggested that most of the 1408 sulphide ores at Garpenberg and Stollberg formed as 1409 synvolcanic stratabound subsea-floor replacements 1410 and that the thin sheet-like superficially stratiform 1411 massive sulphide layers are tectonically mechanically 1412 remobilized ore. They also suggested that much of the 1413 ore deposition occurred by reaction of the ascending 1414 hydrothermal solutions with limestones below the sea 1415 floor. This distinguishes them from VMS deposits 1416 sensu stricto. Also the Zinkgruvan type stratiform $1417 \mathrm{Zn}-\mathrm{Pb}-\mathrm{Ag}$ sulphide deposits are difficult to classify 1418 as VMS deposits sensu stricto (Allen et al., 1996b). 1419 They have some similarities to VMS deposits and to 1420 some stratiform sediment-hosted $\mathrm{Pb}-\mathrm{Zn}$ deposits. 1421 However, they appear most similar to the Broken 1422 Hill-type deposits; sheetlike ore lenses, $\mathrm{Zn}-\mathrm{Pb}-\mathrm{Ag}$ 1423 rich and $\mathrm{Cu}$-poor, mainly pyrite-poor composition, 1424 stratigraphic succession grading from coarse-grained 1425 metavolcanic and metasedimentary rocks below the 1426 ores to pelites above, proximity to banded iron-for1427 mations, association with limestone, calc-silicate 1428 rocks, mafic sills (amphibolites) and unusual chemical 1429 sedimentary rocks such as garnet quartzite.

1430 The volcanic succession in this district is domi1431 nated by calc-alkaline rhyolites with minor calc-alka1432 line dacite and andesite, and chemically unrelated, 1433 probably tholeiitic basalts (Allen et al., 1996a, 1434 2002). The stratigraphy is composed of: (1) a lower, 14351 to $5 \mathrm{~km}$ thick, poorly stratified felsic complex 1436 dominated by a proximal-medial facies of interfinger1437 ing and overlapping large caldera volcanoes, and 1438 minor interbedded marble, (2) a middle, 0.5 to 2.5 $1439 \mathrm{~km}$ thick, well-stratified interval dominated by med1440 ial-distal juvenile volcaniclastic facies and marble 1441 sheets, and (3) an upper, $>3 \mathrm{~km}$ thick, post-volcanic 1442 meta-argillite-turbidite sequence (Allen et al., 1996a). 1443 Depositional environments fluctuated mainly between 1444 shallow and moderately deep subaqueous throughout the lower and middle stratigraphic intervals, and became consistently deep subaqueous in the upper interval (Allen et al., 1996a).

The supracrustal succession has been intruded by syn- and post-volcanic granitoids. The stratigraphy reflects an evolution from intense magmatism, thermal doming, and crustal extension, followed by waning extension, waning volcanism, and thermal subsidence, then reversal from extension to compressional deformation and metamorphism (Allen et al., 2002). The region is interpreted as an extensional intra-continental or continental margin back-arc, region (Allen et al., 1996a).

\subsection{Orogenic gold}

Orogenic gold deposits, following the terminology of Groves et al. (1998), are present in both Archaean and Proterozoic units of the Fennoscandian Shield (Fig. 2). Some gold-only deposits have been described with alternative genetic models; for example, the Enåsen (Hallberg, 1994) and Kutemajärvi (Poutiainen and Grönholm, 1996) have been interpreted as metamorphosed epithermal deposits. The largest gold deposit in the Fennoscandian Shield, the Boliden deposit, has also been described as a hybrid epithermal VMS deposit (Bergman Weihed et al., 1996). In the northernmost part of the Fennoscandian Shield $\mathrm{Cu}-\mathrm{Au}$ deposits such as Bidjovagge (Ettner et al., 1994), Pahtohavare (Lindblom et al., 1996) and Saattopora (Grönholm, 1999) have been described as orogenic gold deposits, but the high content of $\mathrm{Cu}$ makes these deposit more akin to IOCG deposits (see Weihed, 2001).

Although the currently economic deposits are strongly concentrated in the Palaeoproterozoic domains (cf. Sundblad, 2003), tens of occurrences have also been identified in Archaean areas that have been explored for gold by modern methods (Eilu et al., 2003). The apparent scarcity of Archaean economic deposits is probably due to the fact that little exploration for gold has been performed in the Russian part of the shield and that exploration in the Finnish part is relatively recent.

Age data on orogenic gold mineralizing events are scarce, but it is possible to constrain three major periods of mineralization; 2.72 to $2.67,1.90$ to 1.86 and 1.85 to $1.79 \mathrm{Ga}$ (Box 8-2, Eilu and Weihed, 2005,
1445

1446

1447

1448

1449

1450

1451

1452

1453

1454

1455

1456

1457

1458

1459

1460

1461

1462

1463

1464

1465

1466

1467

1468

1469

1470

1471

1472

1473

1474

1475

1476

1477

1478

1479

1480

1481

1482

1483

1484

1485

1486

1487

1488

1489

1490 
1491 this volume), excluding a few minor younger events 1492 (Luukkonen, 1992; Sorjonen-Ward, 1993; Mänttäri, 1493 1995; Bark and Weihed, 2003; Eilu et al., 2003; 1494 Weihed et al., 2003). The age data appear to define 1495 a rough zonation from NE to SW, which seems to be 1496 related to the south-westward growth of the Fennos1497 candian Shield with time.

\section{4.3.1. Geodynamic setting}

1499 The periods of orogenic mineralization in the Fen1500 noscandian Shield fit into two of the main global 1501 periods of orogenic gold mineralization during the 1502 Precambrian, at ca. 2.7 to 2.6 and ca. 1.9 to $1.8 \mathrm{Ga}$, 1503 which correlate with the major episodes of juvenile 1504 continental growth discussed above (Stein and Hof1505 mann, 1994; Goldfarb et al., 2001). More specifically, 1506 the periods of orogenic gold mineralization can be 1507 correlated with the main compressional to transpres1508 sional events, with peak regional metamorphism and 1509 the latest main stage of deformation during major 1510 orogenies in the shield (Luukkonen, 1992; Sorjonen1511 Ward, 1993; Lahtinen et al., 2003; Eilu et al., 2003; 1512 Sundblad, 2003; Weihed et al., 2003):

1513

1514

1515

1516

1517

1518

1519

1520

1521

1522

1523

1524

1525

1526

1527

1528

1529

1530

1531

1532

1533

1534

1535

1536

1537 (i) The 2.72 to $2.67 \mathrm{Ga}$ stage coincides with the global period of accelerated crustal growth near the end of the Archaean.

(ii) The 1.90 to $1.86 \mathrm{Ga}$ stage relates to microcontinent accretion (see Section 5) that formed part of a second peak of crustal growth. For the Archaean units, this includes the collision of the Karelian craton with the Kola craton in the north and Norrbotten craton in the west, as discussed below. Simultaneously, to the SW of the Archaean units, the Palaeoproterozoic Keitele microcontinent collided with the Karelian craton (Lapland-Savo Orogeny), eastward subduction under the Norrbotten craton started at 1.89 to $1.88 \mathrm{Ga}$, the Bergslagen microcontinent started to accrete (Fennian Orogeny), and finally, in the south, the Bothnia and Bergslagen microcontinents amalgamated at 1.87 to 1.86 Ga. The stage resulted in the formation of a large continental plate, the Fennoscandia Plate.

(iii) The 1.85 to $1.79 \mathrm{Ga}$ stage involved collision of the Fennoscandia continental plate with Sarmatia in the SE and Amazonia in the west (Svecobaltic and Nordic orogenies, respectively).

\subsubsection{Timing and relation to regional tectonic} evolution of the shield

Most of the greenstone belts in the Archaean Karelian craton formed after the earliest well-recorded magmatic and metamorphic event at $2.84 \mathrm{Ga}$ and were deformed and intruded by tonalitic to granitic magmas between 2.76 and $2.70 \mathrm{Ga}$ (O'Brien et al., 1993; Vaasjoki et al., 1993, 1999). In the Ilomantsi greenstone belt in the easternmost part of Finland, there is textural and structural evidence that gold mineralization slightly preceded the peak of the regional metamorphism (Sorjonen-Ward, 1993; SorjonenWard and Luukkonen, 2005). Large areas of the Archaean domain were reheated by burial beneath a sequence of nappes in the foreland of the Palaeoproterozoic orogenies around $1.9 \mathrm{Ga}$. Despite also indications of Proterozoic fluid activity in the region (e.g., Poutiainen and Partamies, 2003), there is no evidence for a distinct Proterozoic gold mineralization event in the area (Kontinen et al., 1992; O'Brien et al., 1993). The lack of Proterozoic gold in the Archaean areas could simply be due to the style of the Proterozoic tectonic processes in the area: a system of subhorizontal nappes typically does not contain deep, transcrustal structures necessary to tap the fluid and metal sources and focus enough mineralizing fluids for orogenic gold deposits to form (Goldfarb et al., 2001).

For the Palaeoproterozoic greenstone belts in northern Finland, most of the radiometric age dating and structural evidence suggest mineralization between ca. 1.85 and 1.79 Ga (Sorjonen-Ward et al., 1992; Mänttäri, 1995). On the other hand, structural evidence and a few radiometric ages of the wall-rocks from some of the gold occurrences point towards mineralization between ca. 1.90 and 1.88 Ga (Mänttäri, 1995). In any case, most of the available evidence supports the occurrence of orogenic mineralization in northern Finland during the peak deformation stage of the collisional epoch at 1.85 to $1.79 \mathrm{Ga}$. Two different styles of epigenetic gold occurrence in the region are displayed in Figs. 5 and 6, respectively. The Suurikuusikko deposit (Fig. 7) exhibits features that are typical of shear zone-hosted orogenic gold deposits, whereas the Saattopora $\mathrm{Cu}-$ $\mathrm{Au}$ deposit (Fig. 8) exhibits many features that are typical of orogenic gold lode deposits, but also includes some features characteristic of IOCG deposits (see Box 8-2, Eilu and Weihed, 2005, this volume).
15338

1540

1541

1542

1543

1544

1545

1546

1547

1548

1549

1550

1551

1552

1553

1554

1555

1556

1557

1558

1559

1560

1561

1562

1563

1564

1565

1566

1567

1568

1569

1570

1571

1572

1573

1574

1575

1576

1577

1578

1579

1580

1581

1582

1583

1584

1585

1586 


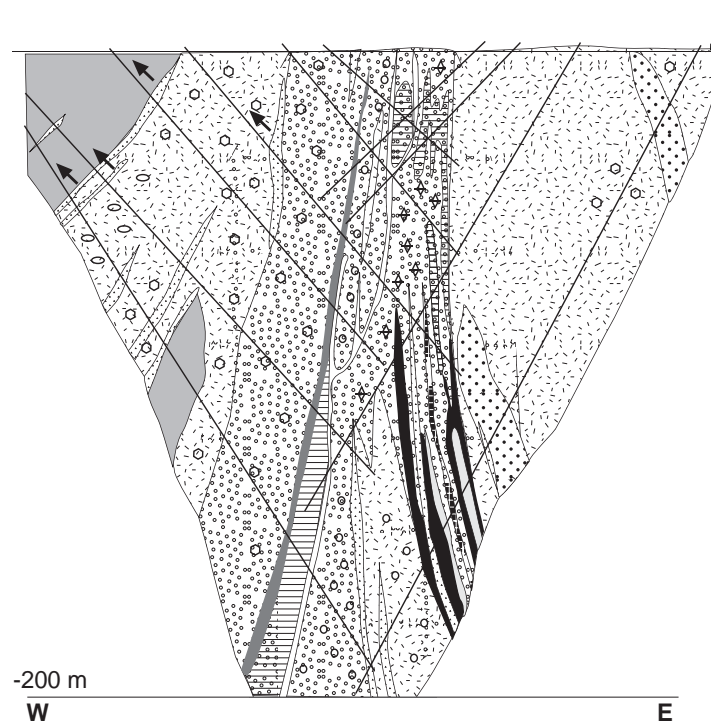

$2558600 \mathrm{E}$
Key:

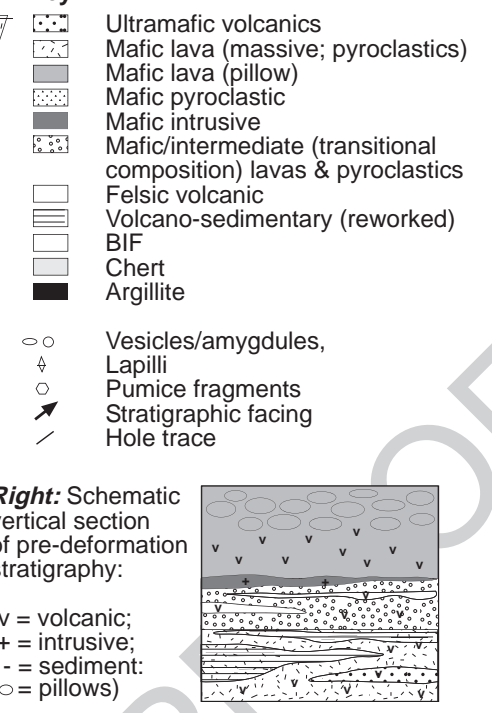

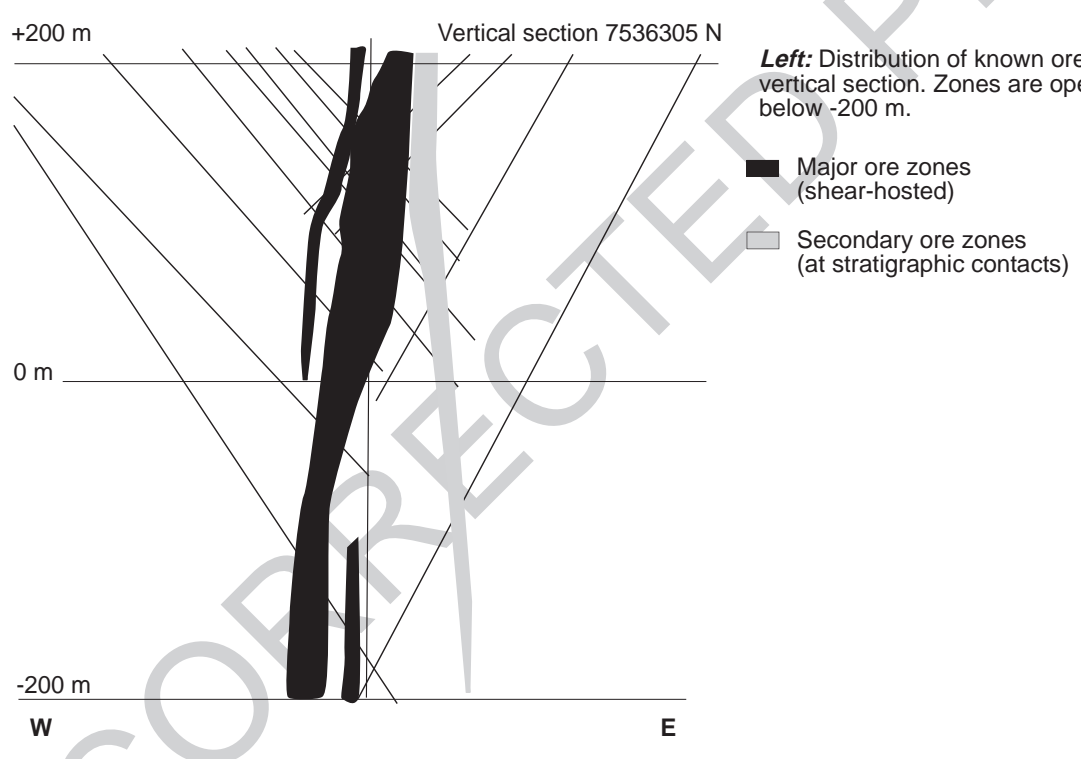

Fig. 7. Simplified vertical cross-section showing the host rocks of the Suurikuusikko gold deposit. Major ore zones typically occur within the central part of the host stratigraphy (Mafic/intermediate (transitional composition) lavas and pyroclastics). These volcanic to volcanogenic sedimentary rocks have a geochemical composition transitional between mafic and intermediate. Primary volcanoclastic textures and thin felsic volcanic layers are also more abundant in this part of the local stratigraphy. Secondary ore zones occur on stratigraphic contacts throughout the entire host rock package. All parts of the local stratigraphy appear to have a geochemical affinity with the 2.012 Ga Vesmajärvi Formation (as defined in Lehtonen et al., 1998). In the structure hosting Suurikuusikko (Kiistala Shear Zone, not shown), the most intense shearing associated (spatially and temporally) with mineralization was focused within the central units of the local stratigraphy.

In the Svecofennian domain of Finland, orogenic 1588 mineralization post-dates the earliest deformation. 1589 However, some of the occurrences were recrystal1590 lized and deformed to varying degrees after miner- alization between 1.84 and $1.80 \mathrm{Ga}$ (e.g., Kontoniemi, 1998). This indicates that the timing of mineralization was either ca. 1.90 to 1.86 or 1.84 to $1.80 \mathrm{Ga}$. 


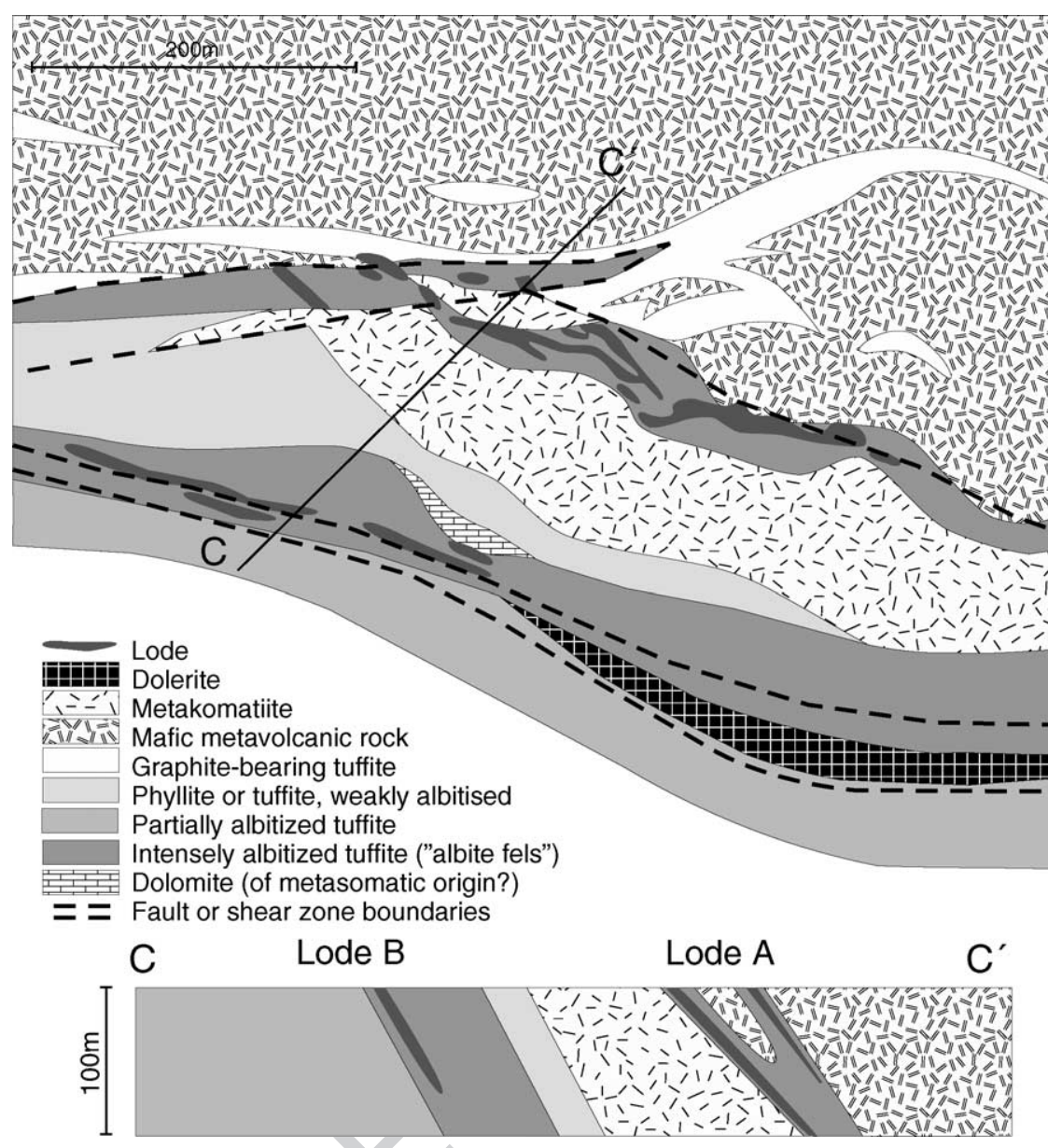

Fig. 8. Plan view and cross-section of the Saattopora deposit. Geology is based on Korvuo (1997); stratigraphy on Lehtonen et al. (1998).

1595 Recent age data on orogenic gold deposits in the 1596 western part of the shield indicate that many of the 1597 deposits, at least in part, formed slightly after peak 1598 metamorphism, as late as ca. 1.79 to $1.77 \mathrm{Ga}$ (Bark 1599 and Weihed, 2003; Weihed et al., 2003). Later remo1600 bilization may also have occurred and there is abun1601 dant evidence for young, post-1.78 Ga, hydrothermal 1602 activity in northernmost Sweden (see Section 4.4).

\section{4.3.3. Controls on mineralization}

1604 Orogenic gold deposits in the Fennoscandian 1605 Shield are structurally controlled. All occurrences 1606 are in second- to lower-order shear or fault zones, at 1607 their intersections, or at the intersections between 1608 antiforms and crosscutting fault and shear zones, all 1609 indicative of a compressional to transpressional regime at the time of mineralization, as exemplified in the Palaeoproterozoic Central Lapland and Kuusamo greenstone belts. In Central Lapland, the W- to NW-trending Sirkka Shear Zone, a major crustal-scale structure, is located close to most of the gold occurrences, which in many cases are in lower-order shear or fault zones branching from the main structure and at localities where younger faults cut across the latter (Eilu et al., 2003). In the Kuusamo greenstone belt, nearly all occurrences are located within two NE- to NW-trending antiforms located in the central part of the greenstone belt, at or near intersections between antiforms and crosscutting faults (Pankka, 1992; Vanhanen, 2001). Similarly, deposits in central and southern Finland display a close association with major faults, but are hosted by second- and third-order 
1626 structures branching from the large faults. In the 1627 Björkdal deposit in the Skellefte district in Sweden, 1628 the gold is related to third-order structures. There, the 1629 gold precipitated in or adjacent to conjugate quartz 1630 veins in the footwall of a major duplex structure that 1631 formed during roughly $\mathrm{E}-\mathrm{W}$ crustal shortening at ca. $16321.80 \mathrm{Ga}$ (Weihed et al., 2003).

1633 On a local scale, favoured sites for gold minerali1634 zation are (1) pre-gold albitized units, (2) competent 1635 units enveloped by softer rocks, and (3) contact zones 1636 between chemically-reactive rocks with a significant 1637 competency difference. There are examples of each of 1638 these in Lapland: in the Saattopora mine (Fig. 8), the 1639 pre-gold albitization significantly increased the com1640 petency of the host tuffites and phyllites, providing 1641 pathways for the mineralizing fluids where these units 1642 were brecciated (Grönholm, 1999). Grönholm (1999) 1643 further suggests that precipitation of gold at Saatto1644 pora was induced by reduction-oxidation reactions 1645 between the mineralizing fluid and graphite in the 1646 albitized wallrock. Increased competency due to pre1647 gold albitization has also been suggested for most of 1648 the Kuusamo deposits (Pankka, 1992; Vanhanen, 1649 2001). A large number of occurrences in Central 1650 Lapland are located in contact zones between chemi1651 cally reactive rocks with a significant competency 1652 difference, for example between intensely carbonated 1653 and more competent metakomatiites and more plastic 1654 graphitic tuffite or phyllite (Eilu et al., 2003). At 1655 Björkdal, the gold mineralization appears to be related 1656 to the competency contrast between the host inter1657 mediate intrusion and the surrounding supracrustal rocks, including a mylonitized marble unit (Weihed et al., 2003). In the Fäbodliden deposit, south of the Skellefte district in Sweden, the gold is spatially related to graphite-bearing pelitic metasedimentary rocks, possibly implying a strong redox control on gold precipitation.

\subsection{IOCG deposits}

The northern region of the Fennoscandian Shield, including parts of Finland, Norway and Sweden, is an economically important metallogenic province dominated by $\mathrm{Fe}$-oxide and $\mathrm{Cu} \pm \mathrm{Au}$ ores. Based on the style of $\mathrm{Fe}$ and $\mathrm{Au}-\mathrm{Cu}$ mineralization and the extensive albite and scapolite alteration, the region has been regarded as a typical IOCG province (e.g., Martinsson, 2001; Williams et al., 2003). These deposits are quite variable in character and include four major types: stratiform $\mathrm{Cu} \pm \mathrm{Zn}$ deposits, skarn-rich iron deposits, Kiruna type Fe-oxide deposits (apatite iron ores), and epigenetic and porphyry style $\mathrm{Cu} \pm \mathrm{Au}$ and Au deposits. In strictly genetic terms only some of these deposits may be classified as typical IOCG deposits whereas others only share a few characteristic features with this rather loosely defined ore type (see Hitzman et al., 1992; Hitzman, 2000). In addition, orogenic gold deposits and subeconomic banded iron formations (BIF) also occur in the region. Some examples of potential IOCG occurrences and their characteristic features are listed in Table 2.

Economically, the most important deposit type for the region has been the apatite-iron ores, presently
1658

1659

1660

1661

1662

1663

1664

1665

1666

1667

1668

1669

1670

1671

1672

1673

1674

1675

1676

1677

1678

1679

1680

1681

1682

1683

1684

1685

1686

1687

\section{t2.1 Table 2}

t2.2 Examples of deposits potentially belonging to the IOCG category in northern Finland and Sweden

Occurrence

Character

\begin{tabular}{|c|c|c|c|}
\hline $\begin{array}{l}\text { Main ore } \\
\text { minerals }\end{array}$ & Alteration & $\begin{array}{l}\text { Hosting } \\
\text { sequence }\end{array}$ & $\begin{array}{l}\text { Approx dep. } \\
\text { age }(\mathrm{Ga})\end{array}$ \\
\hline Mt, Рy, Рo, Сp & $\mathrm{Di}, \mathrm{Bi}, \mathrm{Ab}, \mathrm{Am}$ & SG & 1.86 to 1.76 \\
\hline Mt, Py, Cp, Co & $\mathrm{Am}, \mathrm{Bi}$ & $\mathrm{TF}$ & 1.9 to $1.8 ?$ \\
\hline $\mathrm{Mt},(\mathrm{Ht})$ & $\mathrm{Ab}, \mathrm{Am}, \mathrm{Sc}$ & $\mathrm{KiG}$ & 1.88 \\
\hline $\mathrm{Mt}, \mathrm{Ht}$ & $\mathrm{Am}, \mathrm{Ab}, \mathrm{Bi}, \mathrm{Kf}$ & $\mathrm{KiG} \mathrm{KiG}$ & 1.88 \\
\hline Mt, Cp, Py, Bo & $\mathrm{Kf}, \mathrm{Sc}, \mathrm{Bi}$, To & PoG PoG & $1.77 ?$ \\
\hline $\mathrm{Mt},(\mathrm{Ht}), \mathrm{Py}, \mathrm{Cp}$ & $\mathrm{Kf}, \mathrm{Bi}, \mathrm{Sc}$ & PoG PoG & $1.86 ?$ \\
\hline $\mathrm{Cp}, \mathrm{Py}, \mathrm{Po}$ & $\mathrm{Ab}, \mathrm{Sc}, \mathrm{Bi}, \mathrm{Kf}$ & $\mathrm{KiG} \mathrm{KiG}$ & 1.891 .88 \\
\hline $\mathrm{Bo}, \mathrm{Cc}, \mathrm{Mt}$ & To & KGG & 1.88 to $1.86 ?$ \\
\hline Bo, Cp & $\mathrm{Sc}, \mathrm{To}, \mathrm{Bi}$ & $\mathrm{KiG}$ & 1.76 \\
\hline
\end{tabular}

Fe-oxide-Fe-sulphide-Cu Laurinoja, Kuervitikko

$\mathrm{Fe}-$ oxide $\pm \mathrm{Co}-\mathrm{Cu}-\mathrm{Au}$

Fe-oxide

Fe-oxide-apatite \pm REE

Fe-oxide-apatite- $\mathrm{Cu} \pm \mathrm{Au}$

$\mathrm{Fe}-$ oxide- $\mathrm{Cu} \pm \mathrm{Co} \pm \mathrm{Au}$

$\mathrm{Cu} \pm \mathrm{Au} \pm \mathrm{Fe}$-oxide

$\mathrm{Cu}-\mathrm{Au}$

Pahtohavare
Massive lenses

Breccia

Breccia

Kiirunavaara, Rektorn

Tjårrojåkka Nautanen

Kiskamavaara

Aitik, Pikkujärvi

Lieteksavo Ferrum
Massive lenses

Disseminated, veins

Disseminated, breccia

Disseminated, veins

Vein, disseminated

Bo, $\mathrm{Cp}$

Sc, To, Bi

$\mathrm{KiG}$

1.76 
1688 with an annual production of about $31 \mathrm{Mt}$ of ore from 1689 the Kiirunavaara and Malmberget mines and a total 1690 production of about $1600 \mathrm{Mt}$ from 10 mines during 1691 the last 100 years. Copper and gold have been mined 1692 on a large scale in Sweden (Aitik, Viscaria, Pahtoha1693 vare), Finland (Saattopora, Pahtavaara) and Norway 1694 (Bidjovagge). All of the sulphide deposits are hosted 1695 by Palaeoproterozoic greenstones and are small to 1696 medium sized except for Aitik, which occurs in Sve1697 cofennian volcaniclastic rocks and is a world-class 1698 deposit with a total tonnage $>1000 \mathrm{Mt}$ and an annual 1699 production of $18 \mathrm{Mt}$.

\section{4.4.1. Geodynamic setting}

1701 Fe-oxide and $\mathrm{Cu} \pm \mathrm{Au}$ ores in Norrbotten in north1702 ernmost Sweden formed during the evolution of a 1703 Palaeoproterozoic continental margin arc from ca. 17041.89 to $1.75 \mathrm{Ga}$ (e.g., Juhlin et al., 2002). The deposits 1705 occur where the margin developed above Archaean 1706 continental crust and are hosted both by juvenile rocks 1707 and by older Palaeoproterozoic volcano-sedimentary 1708 sequences formed during rifting of the Archaean cra1709 ton (Martinsson and Weihed, 1999). The rift-related, 17102.2 to $2.0 \mathrm{Ga}$ Karelian greenstones comprise mafic 1711 and ultramafic volcanic rocks, graphitic schists and 1712 sedimentary carbonate rocks. The lower part of the 1713 sequence contains clastic sedimentary and inferred, 1714 evaporitic units (Martinsson, 1997; Vanhanen, 1715 2001). At ca. $1.9 \mathrm{Ga}$, subduction of oceanic crust at 1716 the SW margin of the Karelian craton involved both 1717 strong reworking of older crust and the formation of 1718 juvenile crust by accretion of several volcanic arc 1719 complexes with the cratonic nucleus (see Section 1720 4.2). This ca. 1.90 to $1.88 \mathrm{Ga}$ magmatism is repre1721 sented by the calc-alkaline and andesite-dominated 1722 volcanic successions and the co-magmatic, intrusive 1723 Haparanda Suite within the NW part of the craton. In 1724 the Kiruna area, these rocks are succeeded by the 1725 bimodal Kiirunavaara Group volcanic rocks and the 1726 coeval and chemically similar Perthite Monzonite 1727 Suite (Bergman et al., 2001). This 1.88 to $1.86 \mathrm{Ga}$ 1728 magmatic activity has a more alkaline character that 1729 suggests an extensional intraplate setting.

1730 The magmatism related to the Svecokarelian oro1731 gen after ca. $1.86 \mathrm{Ga}$ is mainly of S-type (1.81 to 1.78 1732 Ga Lina suite intrusions) derived from anatectic melts 1733 in the middle crust. In the western part of the shield, 1734 extensive I- to A-type magmatism formed a roughly
N-S-trending belt of batholiths (the Trans-scandinavian Igneous Belt) coeval with the S-type magmatism, possibly as a result of eastward subduction (Weihed et al., 2002), followed by collision between Fennoscandia and Amazonia (see Section 5). Although the metamorphic history of the northern part of the shield is not well-constrained, in time or in space, it appears that metamorphic peaks more or less overlap with the main magmatic events at about 1.88 and $1.80 \mathrm{Ga}$. A model for the tectonic setting of the IOCG deposits is presented in Fig. 9.

\subsubsection{General features and controls on mineralization}

Skarn-rich and lens- to irregularly-shaped Fe-oxide occurrences consisting of magnetite, and $\mathrm{Mg}$ and $\mathrm{Ca}-$ $\mathrm{Mg}$ silicates are common within the greenstones of northern Sweden and the westernmost part of northern Finland. Some of the deposits are spatially associated with oxide- and silicate-facies BIF. These skarn or skarn-like iron deposits occur in association with tuffite, graphitic schist, and dolomitic to calcitic marble, and are located mainly in the upper parts of the greenstone sequences. These occurrences have previously been suggested to be metamorphic expressions of originally syngenetic exhalative deposits (Frietsch, 1977; Bergman et al., 2001) or intrusionrelated skarn deposits (Hiltunen, 1982). Several skarnrich iron deposits have been mined in the Kolari area in NW Finland and in the Misi region in southern Finnish Lapland (Nuutilainen, 1968; Hiltunen, 1982; Niiranen et al., 2003). In addition, significant amounts of $\mathrm{Cu}$ and $\mathrm{Au}$ have been recovered from the Laurinoja orebody in the Kolari area (Hiltunen, 1982; Geological Survey of Finland, 2004).

Kiruna is the type area for apatite-iron ores (Kiruna type Fe-oxide ores) with the Kiirunavaara deposit as the largest and best known example (Table 1). In all, about 40 apatite-iron deposits are known from the northern Norrbotten ore province in northernmost Sweden. This type of deposits is mainly spatially restricted to areas occupied by the Kiirunavaara Group and very few occurrences exist outside the Kiruna-Gällivare area. The apatite-iron ores exhibit a considerable variation in host rock composition and relationship, alteration, $\mathrm{P}$ content, and associated minor components. It is possible to distinguish two subgroups: breccia deposits and stratiform-stratabound deposits. A third and less distinct group has
1735

1736

1737

1738

1739

1740

1741

1742

1743

1744

1745

1746

1747

1748

1749

1750

1751

1752

1753

1754

1755

1756

1757

1758

1759

1760

1761

1762

1763

1764

1765

1766

1767

1768

1769

1770

1771

1772

1773

1774

1775

1776

1777

1778

1779

1780

1781 


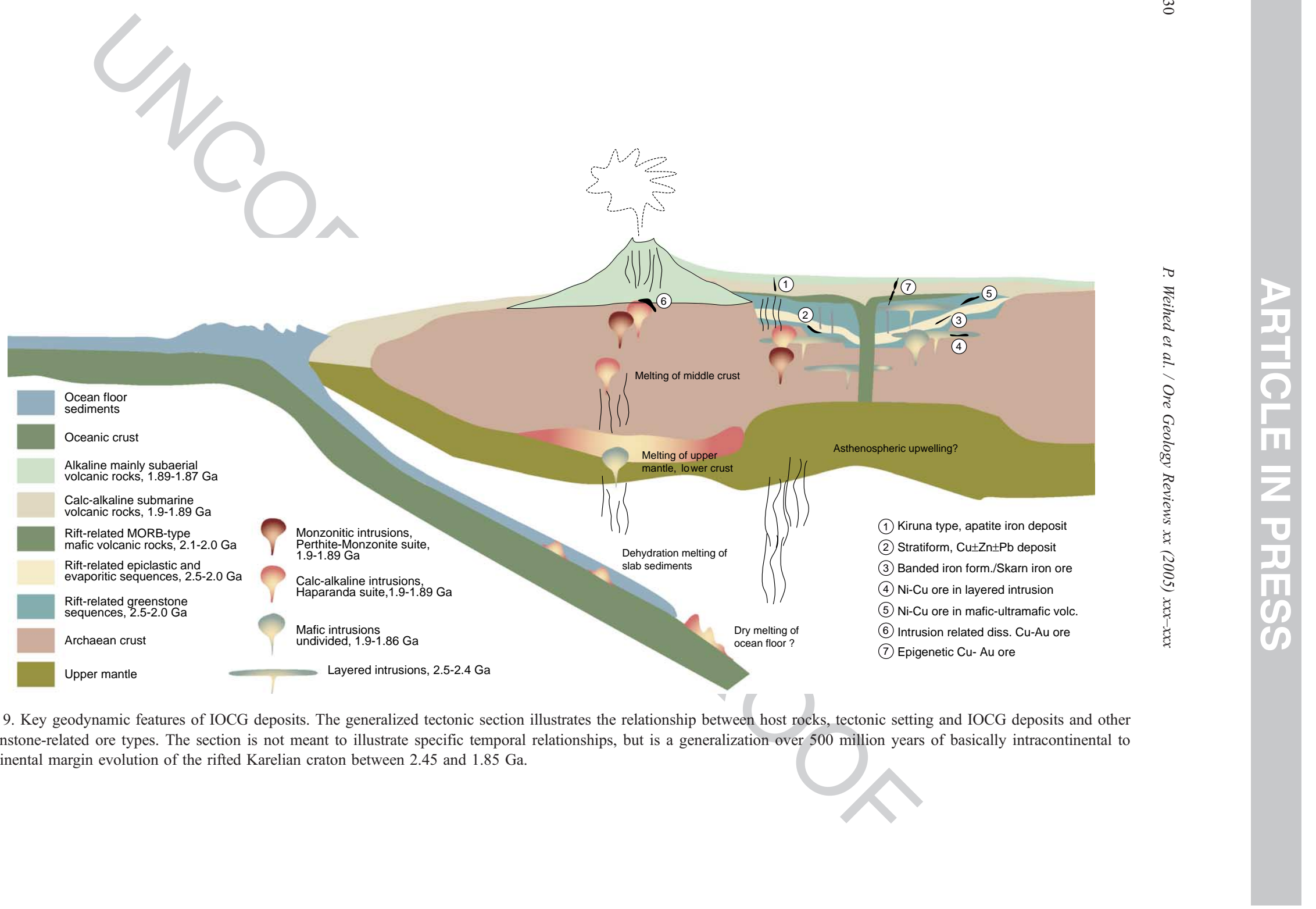

tectonic section illustrates the relationship between host rocks, tectonic setting and IOCG de greenstone-related ore types. The section is not meant to illustrate specific temporal relationships, but is a generalization over 500 million years of basically intracontinental to continental margin evolution of the rifted Karelian craton between 2.45 and $1.85 \mathrm{Ga}$. 
1782 features similar to both of the other two groups (Berg1783 man et al., 2001). Breccia-type apatite-iron ores (e.g., 1784 Mertainen) are mainly associated with intermediate to 1785 mafic volcanic rocks, in a stratigraphically low posi1786 tion of the Svecofennian Kiirunavaara Group or 1787 within the underlying Porphyrite Group. The strati1788 form-stratabound type (e.g., Nukutus, Henry, 1789 Rektorn, Lappmalmen and Ekströmsberg) comprises 1790 hematite-dominated lenses at stratigraphically high 1791 positions within the Kiirunavaara Group. The inter1792 mediate types of apatite-iron ore (e.g., Kiirunavaara 1793 and Tjårrojåkka) are dominantly stratabound in char1794 acter, but have breccia ores developed along the wall1795 rock contacts (Box 8-3, Edfelt and Martinsson, 2005, 1796 this volume). Magnetite is the dominant, or the sole 1797 Fe-oxide.

1798 Apatite-iron ores have been suggested to represent 1799 an iron-dominated and sulphide-poor end member of 1800 the Fe-oxide- $\mathrm{Cu}-\mathrm{Au}$ class of metallic ore deposits 1801 (Hitzman et al., 1992), which makes them important 1802 not only as sources of iron, but also for the metallo1803 genetic understanding of the northern Norrbotten Fe$1804 \mathrm{Cu}-\mathrm{Au}$ province. Suggested genetic models include 1805 sedimentary, hydrothermal or magmatic processes 1806 (Parák, 1975; Hitzman et al., 1992; Nyström and 1807 Henriquez, 1994). Most features of the ores are com1808 patible with either a magmatic intrusive origin or a 1809 hydrothermal origin. Probably both magmatic and 1810 hydrothermal processes were involved, explaining 1811 the large variation in mineralization style recognized 1812 within and between individual deposits. Most of the 1813 massive deposits are suggested to have a mainly 1814 magmatic origin with minor overprinting hydrother1815 mal phases altering the wall-rocks and forming the 1816 veins. Some deposits (e.g., Tjårrojåkka) may represent 1817 transitional forms between a magmatic and hydrother1818 mal origin similar to that at Lightning Creek in the 1819 Cloncurry area, Queensland, Australia (Perring et al., 1820 2000).

1821 Sulphides are mostly rare constituents in the apa1822 tite-iron ores and occur disseminated or in veinlets. 1823 Significant $\mathrm{Cu}$ mineralization spatially associated with 1824 apatite ores occurs only in a few places (e.g., Tjårro1825 jåkka and Gruvberget). A genetic relationship 1826 between $\mathrm{Cu}$ and Fe-oxide mineralization has not 1827 been proved, but is probable at Tjårrojåkka (Edfelt 1828 and Martinsson, 2004). At Gruvberget, the relation1829 ship might be more of a coincidence with the $\mathrm{Cu}$ occurrence representing a later separate event and the iron ore only acting as a chemical-structural trap (Lindskog, 2001). U-Pb titanite ages indicate that $\mathrm{Cu}$ mineralization at Tjårrojåkka and Gruvberget is ca. $1.8 \mathrm{Ga}$ in age (Billström and Martinsson, 2000), which is significantly younger than the suggested ca. $1.9 \mathrm{Ga}$ emplacement age for apatite-iron ores in the Kiruna area.

Epigenetic $\mathrm{Cu} \pm \mathrm{Au}$ deposits form a heterogeneous group with extensive variation in the style of mineralization, metal association and host rock. Most deposits are hosted by tuffitic units of the Karelian greenstones (e.g., in Central Lapland and Kuusamo in Finland) and mafic to intermediate volcanic rocks within the Svecofennian porphyries (e.g., in Porphyrite and Kiirunavaara Groups in Sweden). Some of them display close genetic links (e.g., Aitik), supported by stable isotope and fluid inclusion evidence (Yngström et al., 1986; Wanhainen et al., 2003), and/ or spatial relation to intrusive rocks of the Haparanda and Perthite Monzonite suites, varying in composition from monzodiorite to granite. The deposits with a close genetic link to intrusive rocks are regarded by many authors as porphyry style deposits (see Weihed, 2001; Wanhainen et al., 2003). Magnetite is a common minor component in many occurrences and locally they occur adjacent to major magnetite deposits. A close spatial relationship with regional shear zones is common, with second- to fourth-order structures controlling the location of an occurrence (Eilu et al., in press). In addition to structural traps, chemical traps may also be important with redox reactions involving an originally high graphite or magnetite content of the host rock to trigger sulphide precipitation. In addition to $\mathrm{Cu}$, several occurrences also contain $\mathrm{Co}$ and/or $\mathrm{Au}$ in economic to subeconomic amounts. Other elements that may be significantly enriched include LREE, Ba, U, and Mo (e.g., Martinsson, 2001; Vanhanen, 2001).

Highly saline fluid inclusions with 30 to 45 eq. wt. $\% \mathrm{NaCl}$ and depositional temperatures of 500 to $300{ }^{\circ} \mathrm{C}$ are recorded for the epigenetic $\mathrm{Cu} \pm \mathrm{Au}$ deposits in the region (Ettner et al., 1993; Lindblom et al., 1996; Broman and Martinsson, 2000; Wanhainen et al., 2003; Williams et al., 2003; Edfelt et al., 2004; Niiranen pers. comm. 2004).

Extensive hydrothermal alteration systems producing, for example, scapolite, albite, K-feldspar, bio-
1830

1831

1832

1833

1834

1835

1836

1837

1838

1839

1840

1841

1842

1843

1844

1845

1846

1847

1848

1849

1850

1851

1852

1853

1854

1855

1856

1857

1858

1859

1860

1861

1862

1863

1864

1865

1866

1867

1868

1869

1870

1871

1872

1873

1874

1875

1876

1877 
1878 tite, amphibole and tourmaline characterize the north1879 ern part of the Fennoscandian Shield, indicating 1880 extensive interaction between hydrothermal fluids 1881 and the crust. These systems occur both on a regio1882 nal scale and directly coupled with different kinds of 1883 mineralization (Frietsch et al., 1997; Bergman et al., 1884 2001). The importance of evaporites in the genesis of 1885 Fe-oxide- $\mathrm{Cu}-\mathrm{Au}$ deposits has been argued by Barton 1886 and Johnson (1996) and evaporitic units are sug1887 gested to have been present in the Karelian green1888 stones based on the abundance of albite and scapolite 1889 in certain stratigraphic units (Tuisku, 1985; Martins1890 son, 1997; Vanhanen, 2001; Eilu et al., in press) and 1891 the $\mathrm{Br} / \mathrm{Cl}$ ratio of the ore bearing fluids (Wanhainen 1892 et al., 2003; Williams et al., 2003). On a broad scale, 1893 most of the Kiruna-type Fe-oxide and epigenetic $1894 \mathrm{Cu} \pm \mathrm{Au}$ deposits are located in areas where both 1895 strong $\mathrm{Na}-\mathrm{Cl}$ alteration and calc-alkaline to alkali1896 calcic, monzonitic magmatism occur (Fig. 9). In 1897 areas where either regional scapolitization or monzo1898 nitic magmatism is lacking, only minor deposits are 1899 found. Thus, it seems that continental margin mag1900 matism interacting with evaporitic sequences is a 1901 metallogenetically important feature in the Fennos1902 candian Shield (cf. Fig. 9).

1903 A fairly comprehensive U-Pb age data set exists 1904 for titanite from Kiruna-type Fe-oxide and epigenetic $1905 \mathrm{Cu} \pm \mathrm{Au}$ occurrences, but it should be noted that in 1906 more complex systems with overprinting alteration 1907 assemblages, different titanite age determinations 1908 may occasionally yield disparate ages. Age data dis1909 played in Fig. 10 from epigenetic $\mathrm{Cu} \pm \mathrm{Au}$ deposits 1910 and related hydrothermal alteration systems in the 1911 northern Norrbotten ore province in Sweden indicate

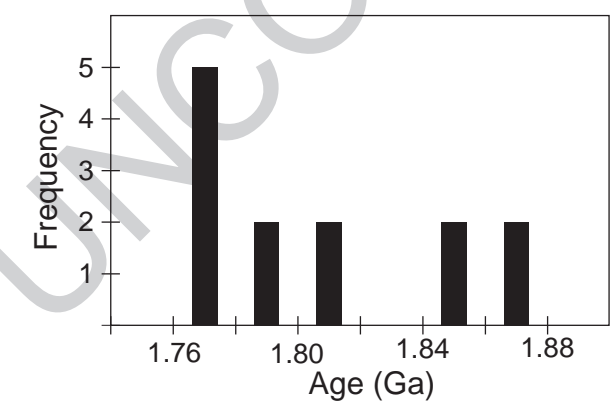

Fig. 10. Histogram showing $\mathrm{U}-\mathrm{Pb}$ titanite ages for epigenetic $\mathrm{Fe}-$ $\mathrm{Cu}-\mathrm{Au}$ occurrences from northern Sweden. Data from Billström and Martinsson (2000) and Billström (unpublished). two major events of ore formation at ca. 1.81 to 1.76 and 1.88 to $1.85 \mathrm{Ga}$ (Billström and Martinsson, 2000). Deposits in the northern parts of Norway and Finland exhibit the same two events plus a third probable stage of mineralization at ca. 1.84 to $1.81 \mathrm{Ga}$ (Bjørlykke et al., 1990; Mänttäri, 1995). Ages for Kirunatype Fe-oxide ores are only published from the Kiruna area and suggest that these ores were formed between 1.89 and $1.88 \mathrm{Ga}$ (Romer et al., 1994; Cliff et al., 1990). Thus, there is both a strong spatial and temporal correlation with the Kiirunavaara Group and a temporal correlation with the older intrusions of the Perthite-Monzonite Suite, co-magmatic with the Kiirunavaara Group rocks.

Fe-oxide- $\mathrm{Cu}-\mathrm{Au}$ style mineralization in the Fennoscandian Shield seems to be a product of multistage magmatic, metamorphic and tectonic processes, invariably involving saline hydrothermal fluids. Several different age groups of mineralization, 1.89 to 1.88 (Kiruna-type Fe-oxide), 1.89 to $1.85,1.84$ to 1.82 , and 1.81 to $1.76 \mathrm{Ga}$ (epigenetic $\mathrm{Cu} \pm \mathrm{Au}$ ), imply that mineralization took place in different tectonic settings. The older Kiruna type Fe-oxide occurrences formed in a continental margin arc, possibly from Fe-oxide magmas genetically related to monzonitic intrusions. High-salinity fluids formed as a result of magma-crust interaction and were responsible for epigenetic $\mathrm{Cu} \pm \mathrm{Au}$ mineralization. The younger deposits formed largely during or slightly after the peak of the orogeny, during convergence, and at least partly by remobilization of older mineralization. The hydrothermal fluids responsible for the younger deposits were focused along crustal-scale shear zones with mineralization in second to fourth order structures.

\subsection{Fe-Ti oxides in anorthosites}

Magmatic ilmenite deposits are typically hosted by massif-type anorthosites. The largest deposit in the world is the Lac Tio ilmenite body in the Havre St Pierre anorthosite complex in Quebec. The second largest, the Tellnes ilmenite norite deposit, sits in the Åna-Sira anorthosite (Fig. 11) in Rogaland, southern Norway. Understanding of the formation of ilmenite deposits thus relies on the nature of the anorthosites, the nature of their parent magma, and the tectonic setting in which they were emplaced.
1947

1912

1913

1914

1915

1916

1917

1918

1919

1920

1921

1922

1923

1924

1925

1926

1927

1928

1929

1930

1931

1932

1933

1934

1935

1936

1937

1938

1939

1940

1941

1942

1943

1944

1945

1946

1948

1949

1950

1951

1952

1953

1954

1955

1956

1957 


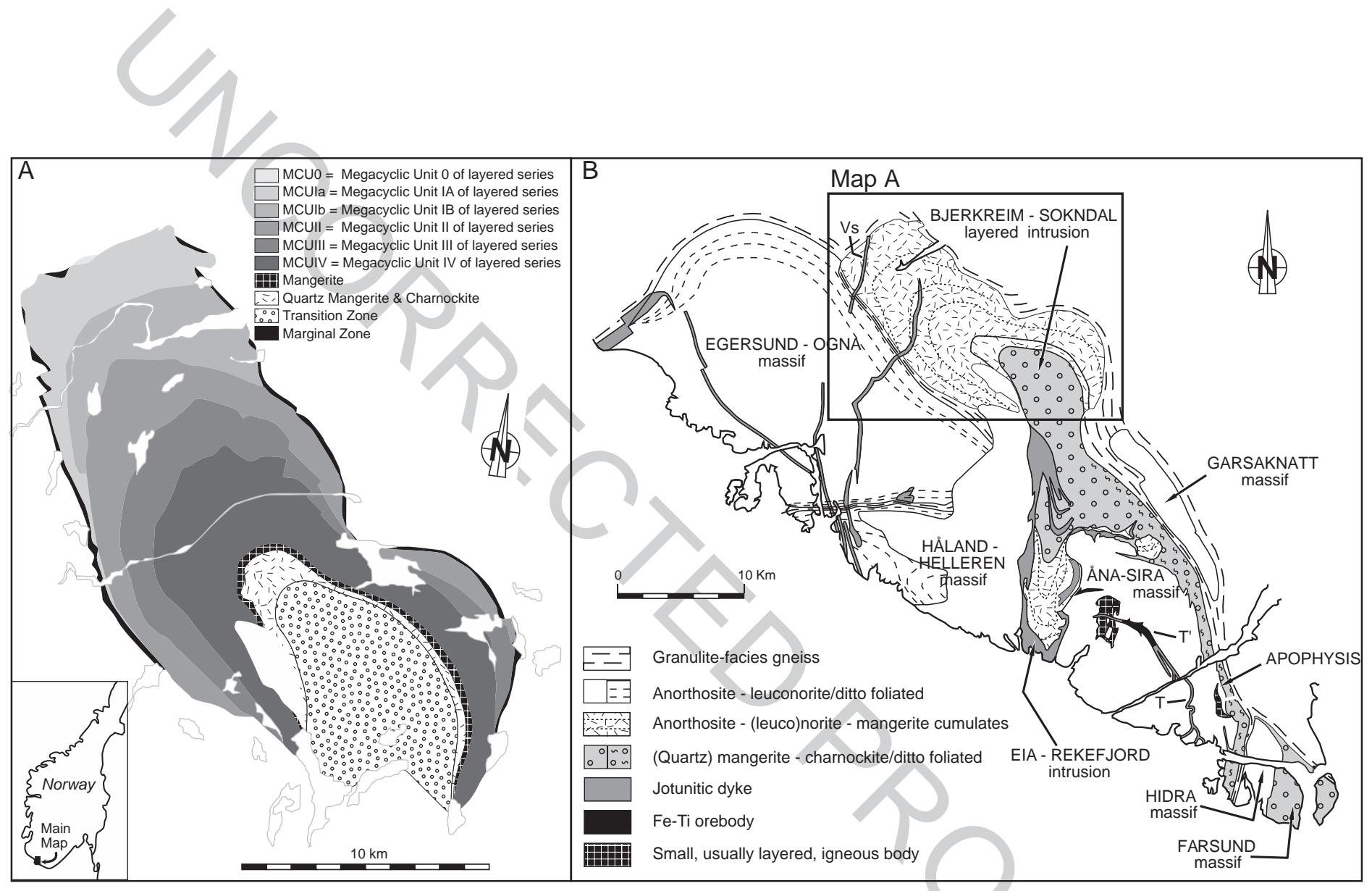

Fig. 11. The geology of the Bjerkreim-Sokndal intrusion, SW Norway, after Robins and Wilson (2001), illustration A; and Duchesne and Bingen (2001), illustration B. T=Tellnes "main dyke"; T"=Tellnes ilmenite deposit. 
1958 The consensus model for anorthosite petrogenesis, 1959 summarized by Ashwal (1993), involves a deep1960 seated magma chamber in which a mantle-derived 1961 mafic magma ponds at the crust-mantle interface. 1962 Differentiation produces a lower density plagioclase 1963 cumulate at the roof of the chamber, from which, due 1964 to gravity instabilities, blobs of plagioclase mush 1965 detach and rise diapirically through the lower crust 1966 to be emplaced at mid-crustal levels, where they 1967 coalesce to form anorthosite plutons.

1968 In the last decade, this model has been improved 1969 and partly modified to account for new field, experi1970 mental and geochemical constraints. The typical high1971 alumina orthopyroxene megacrysts (with plagioclase 1972 exsolutions) that form subophitic aggregates with pla1973 gioclase megacrysts is stable at 10 to $13 \mathrm{kbar}$ in 1974 contrast to the $<5$ kbar pressure of final emplacement 1975 (Fram and Longhi, 1992; Longhi et al., 1993), con1976 firming the polybaric character of the crystallization. 1977 The diapirism mechanism was verified by finite ele1978 ment modelling, taking into account the thermo1979 mechanical properties of anorthosite and mid- and 1980 lower crustal rocks (Barnichon et al., 1999).

1981 Experimental data for dry basaltic systems (Longhi 1982 et al., 1999) show that the parent magma compositions 1983 of anorthosite massifs (high-alumina basalt at Harp 1984 Lake, Nain; hypersthene monzodiorite or jotunite in 1985 Rogaland) occur on a thermal maximum of the plagi1986 oclase + orthopyroxene + clinopyroxene cotectic, in the 1987 pressure range (10 to 13 kbar) typical of the high1988 alumina orthopyroxene megacrysts. Consequently, 1989 the parent magmas cannot be generated by fractiona1990 tion of a mantle-derived basaltic magma, but result 1991 from the melting of a mafic rock (containing plagio1992 clase and two pyroxenes) between 40 and $50 \mathrm{~km}$ 1993 depth. Re-Os isotope data strongly support a mafic 1994 lower crust origin (Stein et al., 1998; Wiszniewska et 1995 al., 2002), particularly in Rogaland where high Os 1996 isotopic ratios can only be accounted for by a mafic 1997 source, because there is no significantly older crust in 1998 SW Scandinavia (Schiellerup et al., 2000).

1999 Detailed field studies in several anorthosite com2000 plexes have shown that anorthosites are frequently 2001 associated with zones of weakness in the crust that 2002 may have favoured their emplacement at mid-crust 2003 levels (Emslie et al., 1994; Scoates and Chamberlain, 2004 1997). In SW Scandinavia, terrane boundaries have 2005 been traced in deep seismic profiles to Moho offsets or to tongues of lower crustal material (the so-called Telemark Craton Tongue) underthrust to depths greater than 40 to $50 \mathrm{~km}$ (Andersson et al., 1996). In Poland the Suwalki anorthosite was emplaced in the Svecofennian platform along the E-W-trending Mazury lineament (Wiszniewska et al., 2002). In Ukraine, the Korosten pluton occurs at the intersection of two lithospheric-scale faults, imaged by geophysical methods (Bogdanova et al., 2004). It has been suggested that such tongues of underthrust, mafic lower crust can reach sufficiently high temperatures to melt and produce the parent magma of massive anorthosites, if accompanied by delamination along the weakness zone and asthenospheric uprise (Duchesne et al., 1999). This hypothesis seems superior to the classical hot-spot hypothesis, which is unable to explain how several generations of anorthosites, separated by hundreds of millions of years, can occur in the same province (Scoates and Chamberlain, 1997; Hamilton et al., 1998). An alternative crustal tongue melting model (Duchesne et al., 1999) links anorthosite production to a local geochemical property of the lower crust, which permits melting each time heat is added.

In the light of these new developments, the concept of an intraplate setting, typical of the consensus model of anorthosite formation, has also been reconsidered. Emplacement along weakness zones can be favoured by relative movements between terranes either in a post-collisional setting or, if a local source of extra heat is provided, during tectonic rejuvenation (Duchesne et al., 1999), possibly due to distant collisions at the margins of the craton.

Ilmenite deposits are hosted in andesine anorthosites (Anderson and Morin, 1969; Ashwal, 1993) and their genesis has been interpreted to reflect complex diapiric evolution of the host anorthosite and fractional crystallization of the parent magma (Duchesne, 1999; Duchesne and Schiellerup, 2001). The diapiric mechanism has been verified by finite element modelling, taking into account the thermo-mechanical properties of anorthosite and mid- and lower-crustal rocks (Barnichon et al., 1999). There are multiple lines of evidence to indicate that the parental magmas of andesine anorthosites are enriched in $\mathrm{Fe}$ and $\mathrm{Ti}$, whichever model is invoked for their genesis. In the underplating model, crystallization of olivine and high alumina orthopyroxene megacrysts in the deep-seated
2006

2007

2008

2009

2010

2011

2012

2013

2014

2015

2016

2017

2018

2019

2020

2021

2022

2023

2024

2025

2026

2027

2028

2029

2030

2031

2032

2033

2034

2035

2036

2037

2038

2039

2040

2041

2042

2043

2044

2045

2046

2047

2048

2049

2050

2051

2052

2053 
2054 magma chamber enriches the residual melts in $\mathrm{Fe}, \mathrm{Ti}$ 2055 and $\mathrm{P}$ to produce ferrodiorite (Ashwal, 1993). In the 2056 crustal tongue melting model, a Fe-Ti-P rich melt, 2057 hypersthene monzodiorite (jotunite), is directly pro2058 duced by dry melting of gabbronorite in the lower 2059 crust (Longhi et al., 1999). In the deep-seated magma 2060 chamber, this melt can generate andesine anorthosite 2061 mushes liable to rise diapirically. The melt can also 2062 rise through dykes to shallower magma chambers 2063 where it can differentiate at lower pressure conditions. 2064 The Bjerkreim-Sokndal layered intrusion in Rogaland 2065 (Duchesne and Hertogen, 1988; Vander Auwera and 2066 Longhi, 1994; Wilson et al., 1996) is an example of 2067 such a hypersthene monzodiorite (jotunite) magma 2068 chamber (Fig. 11).

2069 These Ti-rich magmas are, however, unable to 2070 produce ilmenite concentrations of economic value 2071 under normal conditions. Norite layers rarely contain 2072 more than $8 \% \mathrm{TiO}_{2}$ (Charlier and Duchesne, 2003). 2073 Ilmenite must therefore be concentrated to generate 2074 an orebody. Ilmenite-silicate liquid immiscibility has 2075 long been invoked (Philpotts, 1967) because it seems 2076 to account for field observations of ilmenite dykes 2077 with sharp contacts, suggesting a liquid behaviour of 2078 pure ilmenite (Duchesne, 1996). Although this 2079 mechanism is appealing it has not been confirmed 2080 experimentally (Lindsley, 2003), because of the high 2081 temperature $\left(1400{ }^{\circ} \mathrm{C}\right)$ required to produce pure 2082 ilmenite melt. The apparent liquid behaviour of ilme2083 nite therefore probably results from its ability to 2084 creep in the solid state in response to stress (Paludan 2085 et al., 1994; Duchesne, 1996). Fractional crystalliza2086 tion of hypersthene monzodiorite (jotunite), illustrated 2087 by the succession of cumulates in the Bjerkreim2088 Sokndal intrusion (Wilson et al., 1996) and well con2089 strained experimentally (Vander Auwera and Longhi, 2090 1994), shows that ilmenite is the second mineral to 2091 appear on the liquidus, after plagioclase but before 2092 orthopyroxene. Provided that an adequate mechanism 2093 (crystal sorting, delayed nucleation, oscillation of the 2094 cotectic with pressure, or some other more enigmatic 2095 mechanism) was involved, ilmenite might be sepa2096 rated from plagioclase to form monomineralic layers. 2097 In this respect, the debate is similar to that on the 2098 origin of the chromitite layers of the Bushveld Com2099 plex (Wager and Brown, 1968; Cawthorn, 1996). 2100 Cotectic crystallization of ilmenite and plagioclase, 2101 however, raises another problem. In layered bodies such as the Bjerkreim-Sokndal intrusion, the amount of plagioclase-ilmenite cumulates is small relative to plagioclase-ilmenite-orthopyroxene cumulates and plagioclase-ilmenite-magnetite-orthopyroxene-clinopyroxene-apatite cumulates. In a large deposit such as Lac Tio, the inverse situation is observed; the mass of ilmenite is much greater than the mass of norite and gabbronorites. Selective erosion of the ilmenite-poor rocks is possible, but not completely convincing. Flushing of a magma through an unconsolidated crystal mush in a conduit can account for the large quantity of primitive cumulates, but also begs the question of the norite and gabbronorite counterparts. Finally, solid-state creep can also be invoked to explain the ilmenite enrichment by separating it from the more competent plagioclase (Duchesne, 1999). The diapiric environment of anorthosite in which crystallization and deformation occur at high temperature is suitable for such a mechanism in massif anorthosite-hosted deposits (Duchesne, 1999).

The trace element contents of ilmenite and accompanying magnetite are an important issue because they drastically constrain the economic value of a deposit; $\mathrm{Cr}$ and $\mathrm{Mg}$ are deleterious in ilmenite and $\mathrm{V}$ is beneficial in magnetite. $\mathrm{Cr}$ and $\mathrm{V}$ occur in the magma with different valence states, essentially $3+, 4+$, and $5+$. Only the trivalent species can substitute in ilmenite and magnetite. It can thus be anticipated that the oxygen fugacity will be a controlling factor of the trace element contents (Toplis and Corgne, 2002). The other factors controlling the partitioning of $\mathrm{Cr}$ and $\mathrm{V}$ into oxides are the contents in the parental magma, the degree of fractional crystallization, and the intensity of subsolidus readjustment between oxide minerals (Duchesne, 1999). The mineral/melt partition coefficient for $\mathrm{Mg}$ in ilmenite does not vary with pressure (Vander Auwera et al., 2003) and thus the most critical factor remains the composition of the magma. The content of $\mathrm{Cr}$ and $\mathrm{V}$ in magnetite drastically depends on the degree of evolution of the magma when magnetite appears at the liquidus. Toplis and Corgne (2002) have calculated that in ilmenite-free systems a decrease of oxygen fugacity by two orders of magnitude (e.g., from $\mathrm{NNO}+1$ to NNO-1) will increase the $\mathrm{V}$ content of magnetite by a factor of 3 (e.g., from $1 \% \mathrm{~V}_{2} \mathrm{O}_{5}$ to $3 \% \mathrm{~V}_{2} \mathrm{O}_{5}$ ). Clearly, in ilmenite-bearing systems, the ilmenite content will also be indirectly influenced by such behaviour.
2102 2103 2104 2105 2106 2107 2108 2109 2110 2111 2112 2113 2114 2115 2116 2117 2118 2119 2120 2121 2122 2123 2124 2125 2126 2127 2128 2129 2130 2131 2132 2133 2134 2135 2136 2137 2138 2139 2140 2141 2142 2143 2144 2145 2146 2147 2148 2149 


\section{5. Discussion}

2151 The formation of Precambrian ore deposits has 2152 been studied extensively in most shields around the 2153 world. Genetic models of these deposits have devel2154 oped largely in parallel with the evolving concepts of 2155 Precambrian plate tectonics. Today there is little argu2156 ment about the existence of subduction processes in 2157 the Proterozoic and the late Archaean, but there is a 2158 debate about the rate of subduction, how efficient the 2159 subduction processes were, and the effects of subduc2160 tion on magmatism. As discussed above, geodynamic 2161 processes must have operated very differently from 2162 those of the modern Earth since the mantle was hotter, 2163 leading to more active and voluminous magmatism, 2164 and the degree of mantle melting was probably 2165 greater, leading to more Mg-rich magmas. Faster 2166 moving, hotter Archaean (and Palaeoproterozoic) 2167 plates also probably accumulated less sediment and 2168 contained a thinner section of lithospheric mantle 2169 (Sleep and Windley, 1982).

2170 Precambrian continental crust formed episodically 2171 around ca. 2.7, 2.5, 2.1 and 1.9 to $1.8 \mathrm{Ga}$ (Goldstein 2172 et al., 1997; Condie, 1999). As noted above, these 2173 peaks are interpreted by some authors as the times of 2174 supercontinent formation: for Fennoscandia, the data 2175 simply suggest that they represent periods of 2176 enhanced crustal growth and possibly accelerated 2177 mantle convection. However, economic mineral 2178 deposits in the Fennoscandian Shield are mainly 2179 hosted in Palaeoproterozoic rocks. Only a few sig2180 nificant examples of Archaean orogenic gold and Ni$2181 \mathrm{Cu}$ deposits are known. In Ilomantsi, the gold miner2182 alization slightly preceded or was synchronous with 2183 the peak of the regional metamorphism (Sorjonen2184 Ward, 1993). There is no really good understanding 2185 as to why the Archaean seems to be less prospective 2186 in the Fennoscandian Shield compared with most 2187 other shield areas. One possible reason is that large 2188 parts of the Archaean greenstone belts are located in 2189 Russia and are under-explored by modern standards. 2190 Also parts of the Archaean in Finland, especially 2191 under thick overburden, are under-explored. Large 2192 areas of the Archaean have also experienced a sub2193 stantial Palaeoproterozoic thickening, which might 2194 have produced an erosional level devoid of green2195 stone belts. The period from ca. 2.74 to $2.69 \mathrm{Ga}$ 2196 corresponds to a period of intense intrabasinal mantle plumes and a subsequent global plume-breakout event (Barley et al., 1998). The greenstone belts in the Fennoscandian Shield seem to be slightly older than the global Neoarchaean peak in mineralization and mantle plume activity (e.g., Huhma et al., 1999) and, hence, magmatism and hydrothermal activity might have been less intense and unable to form major $\mathrm{Ni}_{-}$ PGE and VMS deposits. This could also explain the lack of large orogenic gold deposits related to subsequent accretion during peak orogeny.

In contrast to the Archaean, the Palaeoproterozoic sequences are intensely mineralized and contain a wealth of economic mineral deposits. It is therefore suitable here to discuss the Palaeoproterozoic geodynamic evolution and metallogeny in more detail, especially for the time period from ca. 2.1 to 1.8 $\mathrm{Ga}$ when the vast majority of known economic deposits formed. We will utilize a slightly modified version of the recent geodynamic model for this period by Lahtinen et al. (2005), which is displayed in Fig. 12 as twelve generalized cartoons (a-1), showing the plate tectonic geometry at different stages between 2.06 and $1.78 \mathrm{Ga}$. The ore deposit types discussed in this paper are also indicated for those stages during which they are suggested to have formed. The cartoons are accompanied by schematic cross-sections (Fig. 13, adapted from Lahtinen et al., 2005), displaying the tectonic environments of ore formation. The geodynamic settings of ore deposits are discussed below within the framework of (1) Palaeoproterozoic rifting of the Archaean continent at 2.5 to $2.06 \mathrm{Ga}$, (2) microcontinent accretion at 1.96 to $1.88 \mathrm{Ga}$, (3) continent-continent collision at 1.87 to $1.79 \mathrm{Ga}$ and (4) oblique continent-continent collision at 1.84 to $1.78 \mathrm{Ga}$.

\subsection{Palaeoproterozoic rifting of the Archaean continent at 2.5 to $2.06 \mathrm{Ga}$}

The Archaean cratonic nucleus of the Fennoscandian Shield rifted in several stages during the Early Proterozoic. The hot spot-related rifting event at 2.4 $\mathrm{Ga}$ is manifested in layered igneous complexes, mafic dyke swarms, intracontinental and continental margin volcanism, and epicontinental sedimentation. Erosion of the Archaean craton is indicated by numerous coarse clastic units deposited within rift basins during the time interval between 2.5 and $2.06 \mathrm{Ga}$.
2234

2235

2236

2237

2238

2239

2240

2241

2242 

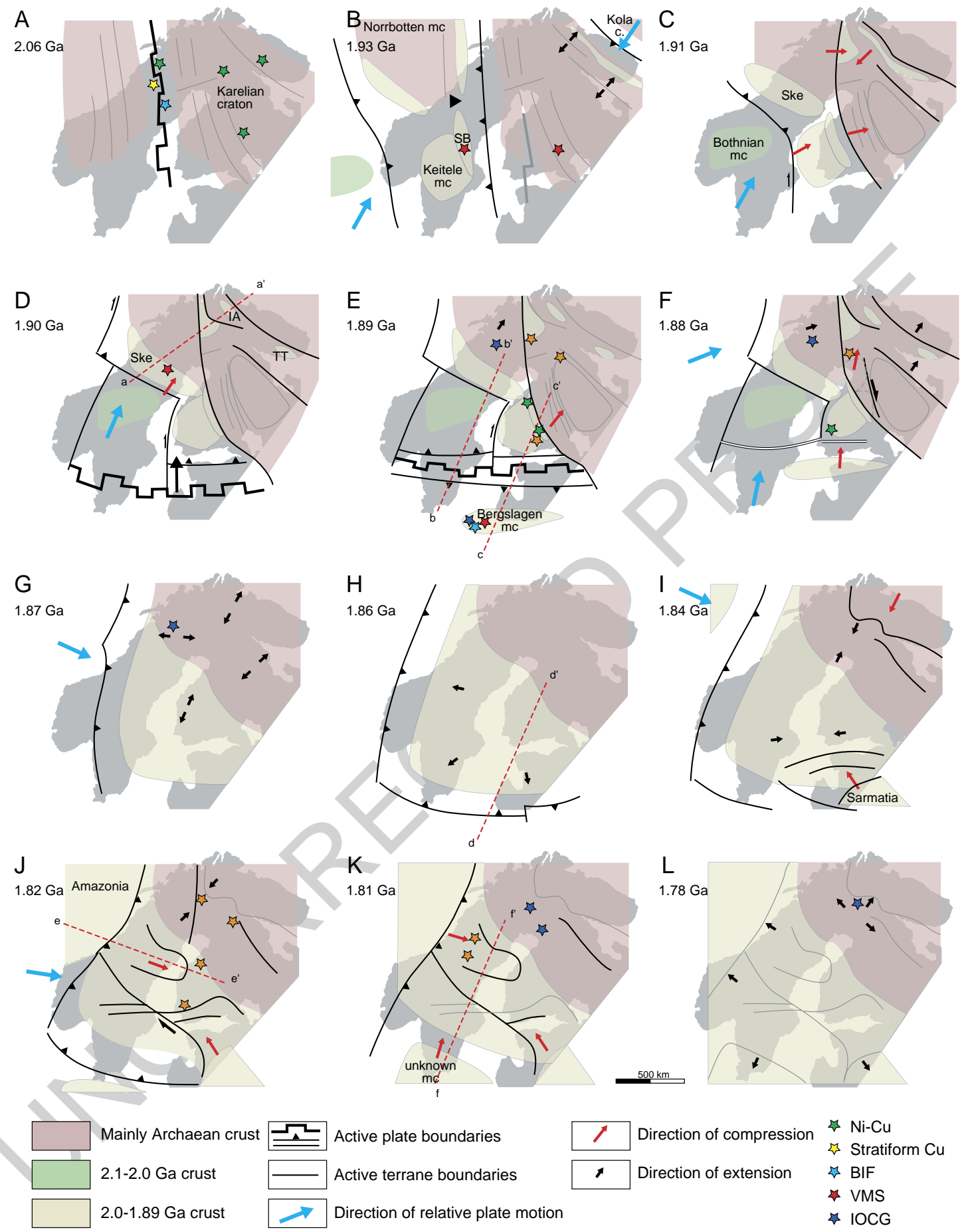

Active plate boundaries

Active terrane boundaries

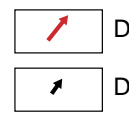

$\rightarrow \mathrm{Ni}-\mathrm{Cu}$

\&s Stratiform $\mathrm{Cu}$

Direction of relative plate motion

\& BIF

$\checkmark$ VMS

$\$$ IOCG

\& Orogenic Gold

Fig. 12. The geodynamic evolution of the Fennoscandian Shield between 2.06 and 1.78 Ga after Lahtinen et al. (2005). The temporal and spatial relationship between tectonic setting and ore types is indicated and discussed in the text. Generalized cross-sections a-a' to $\mathrm{f}-\mathrm{f}$ ' are shown in Fig. 13. 


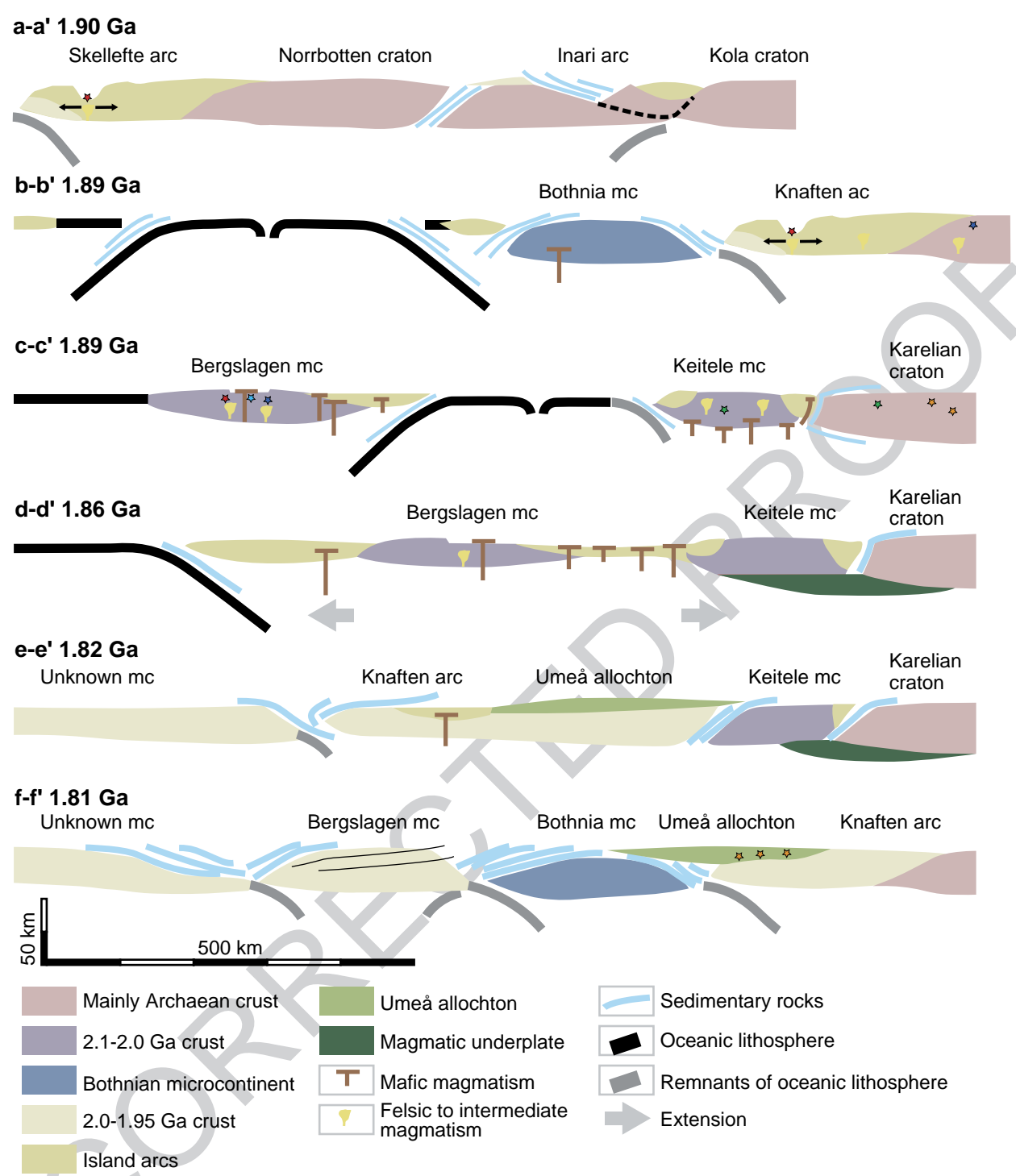

Fig. 13. Generalized cross-sections indicated in Fig. 12 after Lahtinen et al. (2005). Stars denote mineralization styles as in Fig. 12. $\mathrm{mc}=$ microcontinent. According to Lahtinen et al. (2005) lithologic, geochemical, isotopic and geophysical data suggest the following pre1.92 Ga components in the Fennoscandian Shield, illustrated in the cross-sections:

- The Karelian, Kola and Norrbotten Archaean cratons

- The Keitele, Bergslagen and Bothnia $>2.0 \mathrm{Ga}$ age microcontinents

- The Kittilä $\sim 2.0 \mathrm{Ga}$ island arc and oceanic crust

- The Savo, Knaften, Inari and Tersk $\sim 1.95$ Ga island arcs

The Karelian and Kola cratons are well exposed, whereas the Norrbotten craton is not exposed. The Paleoproterozoic microcontinents Keitele, Bergslagen and Bothnia have no identifed surface expressions. The Kittilä and Savo arcs are partly exposed and only small slivers of the Knaften arc are found at surface. The relationship of the Inari and Tersk arcs with the Archaean crust is not well known. The Umeå allochthon consists of a pre 1.9 Ga rock sequence, which is overlain by younger rocks in the Bothnian basin. 
2243 In this environment, the mafic layered intrusions 2244 that were emplaced during the early phases of the 2245 rifting of the craton contain major chromitite and Ni$2246 \mathrm{Cu}$ sulphide-PGE deposits. In the rift basins, conti2247 nental to submarine volcanism, ranging in composition 2248 from ultramafic to mafic and intermediate, is asso2249 ciated with iron formations, but also with 2.2 to 2.05 $2250 \mathrm{Ga}$, low-grade, $\mathrm{Ni}-\mathrm{Cu}$ and PGE deposits within 2251 layered igneous complexes (e.g., Keivitsa) and high2252 grade $\mathrm{Ni}-\mathrm{Cu}$ deposits in ultramafic volcanic rocks and 2253 fractionated mafic-ultramafic intrusions (e.g., Pe2254 chenga). In some of the rift basins, stratiform $2255 \mathrm{Cu} \pm \mathrm{Fe}$-oxide deposits formed within volcaniclastic 2256 units of the greenstone belts (Inkinen, 1979; Martins2257 son, 1997). The largest and sole economic deposit of 2258 this category is the Viscaria $\mathrm{Cu}$ deposit in Kiruna. 2259 The tectonic situation at the end of extension and the 2260 onset of convergence, leading to basin inversion, and 2261 the Svecokarelian orogen (below subdivided into 2262 several discrete tectonic events) are illustrated in 2263 Fig. 12.

\section{5.2. Microcontinent accretion at 1.96 to $1.88 \mathrm{Ga}$}

2265 The first prominent evidence of convergence is the 2266 obduction of ca. 1.97 to $1.96 \mathrm{Ga}$ ophiolitic sequences 2267 at Jormua and Outokumpu in Finland. These ophio2268 litic slices contain VMS-like deposits. However, as 2269 they have recently been described as hosted by mantle 2270 rocks (Kontinen, 1998; Sorjonen-Ward et al., 2004), 2271 an exhalative or shallow subseafloor replacement ori2272 gin is excluded and they cannot be classified into the 2273 VMS category sensu stricto. The tectonic situation 2274 after the obduction of these ophiolites is illustrated 2275 in Fig. 13 where subduction and back-arc rifting in the 2276 Lapland-Kola area, westward subduction under the 2277 Keitele microcontinent (Savo Belt) and Norrbotten 2278 microcontinent (Kittilä), and NE subduction under 2279 the Norrbotten microcontinent are the main tectonic 2280 features at ca. $1.93 \mathrm{Ga}$. A rifted primitive island arc 2281 complex (the Savo belt), formed by north-eastward 2282 subduction west of the craton, contains the VMS 2283 deposits formed in the Pyhäsalmi area in Finland 2284 (Lahtinen, 1994).

2285 The Savo belt was accreted to the craton at ca. 1.91 2286 to $1.90 \mathrm{Ga}$ during the peak of the Lapland-Kola and 2287 Lapland-Savo orogenies (Fig. 12C, D). The initial 2288 stage of collision of the Bothnian microcontinent with the Norrbotten and Keitele microcontinents also occurred at this stage. Large areas of the Archaean domain were reheated by burial beneath a sequence of nappes in the foreland of the Palaeoproterozoic orogens around $1.9 \mathrm{Ga}$, but there is no evidence for a distinct Proterozoic gold mineralization event in the area at this stage. The Skellefte arc formed during the collision of the Bothnian microcontinent with the Norrbotten and Keitele microcontinents (Fig. 12D), either as a continental margin arc or possibly as an accreted island arc. There is evidence that this extensively mineralized arc was under extension during the formation of the VMS ores (Allen et al., 2002). Extension in the Skellefte district was followed by basin inversion and rapid uplift and erosion of the arc. Porphyry copper deposits were formed at this stage, and also on the continent side of the arc (Weihed et al., 1992). Docking of the Bothnian microcontinent with the Norrbotten and Keitele microcontinents and differences in relative plate motions resulted in a transform fault between the Keitele and Bothnian microcontinents (Fig. 12D). Polarity reversal of subduction, and the onset of subduction towards the north under the Keitele microcontinent, was also initiated at ca. $1.90 \mathrm{Ga}$ (Fig. 12D).

During subduction switchover and the onset of subduction towards the north under the Bothnian microcontinent, magmatism was intense along the craton margin. During crustal shortening, orogenic gold mineralization occurred in the thickened crust within accreted terranes at ca. 1.89 to $1.88 \mathrm{Ga}$, during which period metamorphism peaked within the craton. Subduction under the Keitele microcontinent locked up and the ocean basin was consumed by subduction towards the south under the combined Uusimaa island arc and the Bergslagen microcontinent (Fig. 12E, F). Magmatism along the craton margin produced mafic intrusion-hosted $\mathrm{Ni}-\mathrm{Cu}$ deposits. Magmatic hydrothermal fluids and fluids derived from heating of evaporitic sequences in the rift-related greenstone sequences within the craton, possibly related to extension of the continental crust, formed iron-oxide and IOCG deposits in areas underlain by older Palaeoproterozoic cratonized crust. The Bergslagen microcontinent started to accrete from the south due to consumption of the ocean by subduction at ca. $1.88 \mathrm{Ga}$. In extensional settings within continental margin arcs within the Bergslagen continent, VMS, 
2337 iron-oxide and banded iron formations formed, clo2338 sely related in space and time.

2339 The peak of the Svecokarelian Orogeny at ca. 1.88 2340 to $1.87 \mathrm{Ga}$ in the eastern part of the shield involved a 2341 strong compressional stage. The Keitele-Bergslagen 2342 collision resulted in substantial shortening within the 2343 collision zone, overthrusting at the western margin of 2344 the Karelian craton, basin inversion in Lapland, and 2345 reactivation of the Lapland-Savo suture zone. Sub2346 duction beneath the Bothnian microcontinent was still 2347 active. Subduction towards the east under the Norr2348 botten microcontinent commenced and local exten2349 sional domains in the Kola and Belomorian areas 2350 were initiated (Fig. 12F, G). The continued crustal 2351 shortening within the craton resulted in orogenic 2352 gold mineralization, especially in the eastern part of 2353 the shield.

2354 5.3. Continent-continent collision between 1.87 and $23551.79 \mathrm{Ga}$, and possible orogenic collapse

2356 The period between 1.87 and $1.83 \mathrm{Ga}$ is still rather 2357 poorly understood in terms of tectonic evolution. 2358 There is evidence of scattered magmatism within the 2359 craton as well as deformation and metamorphism that 2360 may have peaked later in the western part of the 2361 shield. Lahtinen et al. (2005) propose an attempted 2362 orogenic collapse of the Svecokarelian orogen at ca. 23631.87 to $1.85 \mathrm{Ga}$, whilst at the western margin the 2364 subduction zone migrated southwards (Fig. 12G, H). 2365 There is, however, little hard evidence for orogenic 2366 collapse and, in fact, many orogenic gold occurrences, 2367 notably in Finland, possibly formed within this time2368 frame (Eilu et al., 2003). At the southern margin of the 2369 craton, subduction towards the SE and the NE was 2370 initiated (c.f., sections d-d' and f-f' in Fig. 13) and, 2371 according to Lahtinen et al. (2005), large-scale exten2372 sion took place in the hinterland. After ca. $1.87 \mathrm{Ga}$ 2373 there is little evidence of any other major ore forma2374 tion until crustal shortening related to E-W subduc2375 tion and subsequent continent-continent collision at 2376 ca. 1.84 to $1.78 \mathrm{Ga}$.

2377 5.4. Oblique continent-continent collision at 1.84 to $23781.78 \mathrm{Ga}$

2379 The Sarmatian crustal segment collided with the 2380 SE margin of Fennoscandia at ca. 1.84 Ga (Fig. 12I).
This initiated what Lahtinen et al. (2005) refer to as the Svecobaltic Orogeny, expressed as basin inversion and thrusting. Subduction in the $\mathrm{W}$ and SW was still active and docking of Laurentia to Fennoscandia in the NE led to the final emplacement of the Lapland Granulite Belt and reactivation of the Belomorian mobile zone. The peak of the Svecobaltic Orogeny and the onset of the Nordic Orogeny occurred at ca. $1.82 \mathrm{Ga}$ (Lahtinen et al., 2005). The oblique collision of Fennoscandia with Sarmatia resulted in the migration of a transform fault within the continent. This crustal-scale shear zone divided the Svecobaltic orogen into two different compressional regimes, a retreating subduction zone active in the SW, whilst a transpressional regime prevailed in the SE. The Nordic Orogeny started with collision of Amazonia and Fennoscandia in the NW with crustal-scale thrusting occurring in the hinterland (Fig. 12J). This collision caused crustal shortening in the hinterland and fluids circulating in the middle to upper crust formed orogenic gold deposits in, at least, the western part of the shield. Far-field effects of this collision may also have caused reactivation of shear zones further east and orogenic gold mineralization may also have occurred in the eastern part of the craton in Finland. The crustal shortening caused extensive deformation and metamorphism as well as partial melting of the middle continental crust. These processes also led to latestage remobilization and formation of $\mathrm{Cu}-\mathrm{Au}$ occurrences within the NW part of the shield in the hinterland to the active collision. Subsequent amalgamation of Laurentia, Fennoscandia, Amazonia, Sarmatia and an unknown continent in the SW came to an end at ca. 1.81 to $1.79 \mathrm{Ga}$, forming the Palaeoproterozoic supercontinent (Fig. 12J, K). The westward growth of the Fennoscandian Shield was initiated and the Fennoscandian Shield was stabilized between 1.79 and 1.77 Ga (Fig. 12L).

The Anorthosite-hosted Ti-deposits in the SW part of the shield are related to continued westward growth and orogenic stacking in the craton. The Tellnes Tideposit occurs in part of the 930 to $920 \mathrm{Ma}$ (Schärer et al., 1996) Rogaland Anorthosite Province, (Charlier, 2005, Box 8-4). This magmatic province was formed in the SW part of the Sveconorwegian orogen during granulite facies metamorphism, post-dating the last regional deformation by ca. 40 million years (Box 8-4, Charlier, 2005, this volume).
2381

2382

2383

2384

2385

2386

2387

2388

2389

2390

2391

2392

2393

2394

2395

2396

2397

2398

2399

2400

2401

2402

2403

2404

2405

2406

2407

2408

2409

2410

2411

2412

2413

2414

2415

2416

2417

2418

2419

2420

2421

2422

2423

2424

2425

2426

2427

2428 


\section{6. Conclusions}

2430 The Palaeoproterozoic, not the Archaean, hosts 2431 most of the economic mineral deposits in the Fen2432 noscandian Shield. Although the reason for this is not 2433 fully understood, the fact that a major part of the 2434 Archaean located in Russia is under-explored by 2435 modern standards may be one reason why not many 2436 major deposits have been found in the Archaean 2437 units. Another reason might be that most of the 2438 Archaean greenstone belts seem to be slightly older 2439 than the global Neoarchaean peak in mineralization 2440 and mantle plume activity (e.g., Huhma et al., 1999) 2441 and, hence, magmatism and hydrothermal activity 2442 might have been less intense and unable to form 2443 major deposits.

2444 In contrast, the Palaeoproterozoic is well endowed 2445 with metallic resources. It appears that Precambrian 2446 geodynamics involved faster moving, hotter plates 2447 that accumulated less sediment and contained a thin2448 ner section of lithosphere mantle than the present 2449 plate-tectonic processes. This scenario also fits with 2450 the complex evolution of the Fennoscandian Shield 2451 between 2.06 and $1.78 \mathrm{Ga}$, when rapid accretion of 2452 island arcs and several microcontinent-continent col2453 lisions in a complex array of orogens was manifested 2454 in short-lived but intense orogenies. Most of the major 2455 ore deposits in the area also formed during this evolu2456 tionary stage and thus a strong geodynamic control on 2457 ore deposit formation is suggested.

2458 Throughout the evolution of the Fennoscandian 2459 Shield the orogenic gold deposits, where direct or 2460 indirect constraints on age are available, also reflect 2461 the orogenic younging of the shield towards the SW 2462 and west. Most orogenic gold deposits formed during 2463 periods of crustal shortening and mineralization pro2464 cesses peaked at 2.72 to $2.67,1.90$ to 1.86 , and 1.85 to $24651.79 \mathrm{Ga}$.

2466 At ca. 2.5 to $2.4 \mathrm{Ga}$ the Archaean craton rifted for 2467 the first time, facilitating the emplacement of exten2468 sive layered intrusions and mafic dyke swarms. At his 2469 stage and, to some extent, also during the later rifting 2470 stages at 2.2 to $2.05 \mathrm{Ga}, \mathrm{Ni}-\mathrm{Cu} \pm$ PGE deposits 2471 formed both as part of layered igneous complexes 2472 and associated with mafic volcanism in the rift basins. 2473 Synorogenic mafic-ultramafic intrusions formed dur2474 ing the peak of the Svecokarelian orogen at ca. 1.89 to $24751.88 \mathrm{Ga}$. These host numerous $\mathrm{Ni}-\mathrm{Cu}$ deposits and are confined to linear belts that slightly post-date arc volcanism.

Nearly all VMS-style deposits in the Fennoscandian Shield formed during the time span between 1.97 and $1.88 \mathrm{Ga}$ in extensional settings during basin inversion and accretion. The oldest, the Outokumputype ophiolitic $\mathrm{Cu}-\mathrm{Co}-\mathrm{Au}$ deposits were apparently formed at ca. $1.97 \mathrm{Ga}$ in mantle rocks and were obducted on to the Archaean continent during onset of convergence. The next, more typical VMS deposits formed at 1.93 to $1.91 \mathrm{Ga}$ in an accreted, primitive, bimodal arc setting formed during extension of only slightly older volcanic crust in the Pyhäsalmi area in central Finland. Their host rocks are tholeiitic basalts and transitional to calc-alkaline rhyolites, including high-silica varieties, and the deposits broadly fit within the "bimodal mafic type" classification of Barrie and Hannington (1999). The Skellefte VMS deposits are 20 to 30 million years younger and Allen et al. (2002) suggest that, in contrast to the VMS deposits of the Pyhäsalmi area, the district is a remnant of a strongly extensional intra-arc region that developed on continental or mature arc crust where the basement was only slightly older. The Bergslagen-Uusimaa belt, with a much more diverse metallogeny compared to the Skellefte and Pyhäsalmi areas, is coeval with the Skellefte area, but was formed within or at the margin of a microcontinent that collided with Fennoscandia at ca. 1.88 to $1.87 \mathrm{Ga}$. The Bergslagen region is interpreted as an intra-continental extensional or continental margin back-arc region developed on older continental crust.

IOCG occurrences in the Fennoscandian Shield are diverse in style. At least the oldest mineralizing stages at ca. $1.88 \mathrm{Ga}$ are coeval with magmatism having a monzonitic fractionation trend and calc-alkaline to alkaline subaerial volcanism more akin to continental arc or magmatism inboard of an active arc. There is also evidence for multiple metal introduction or remobilization between ca. 1.80 and $1.77 \mathrm{Ga}$ related to late- to post-orogenic magmatism distal to the active N-S subduction zone in the west. Models have also been suggested where the interaction of magmas with evaporitic sequences in the older Palaeoproterozoic rift sequences is important for forming fluids that have the right composition to carry large amounts of $\mathrm{Fe}, \mathrm{Cu}$ and $\mathrm{Au}$.

Large volumes of anorthositic magmas characterize the Sveconorwegian Orogeny, in the SW part of the
2476

2477

2478

2479

2480

2481

2482

2483

2484

2485

2486

2487

2488

2489

2490

2491

2492

2493

2494

2495

2496

2497

2498

2499

2500

2501

2502

2503

2504

2505

2506

2507

2508

2509

2510

2511

2512

2513

2514

2515

2516

2517

2518

2519

2520

2521

2522

2523 
2524 Fennoscandian Shield. The best example of a major 2525 concentration of Ti associated with these anorthosites is 2526 the Tellnes deposit. The Tellnes ilmenite deposit 2527 belongs to the Mesoproterozoic (930 to $920 \mathrm{Ma}$ ) Roga2528 land Anorthosite Province in SW Norway. The rocks of 2529 this province were emplaced in the SW part of the 2530 Sveconorwegian orogenic belt under granulite facies 2531 conditions, ca. 40 million years after the last regional 2532 deformation of the Sveconorwegian Orogeny.

2533 This paper has demonstrated the intimate interplay 2534 between Precambrian geodynamics and metal concen2535 trations. All ore types discussed in this paper ultimately 2536 have their genesis determined by their tectonic setting 2537 and therefore the understanding of geodynamic pro2538 cesses in the Precambrian will be a critical part in future 2539 sustainable exploration and exploitation of metal 2540 resources in shield areas around the world.

\section{Acknowledgements}

2542 We would like to thank Nicole Patison of Riddar2543 hyttan Resources AB for providing the cross-section 2544 of the Suurikuusikko deposit. Discussions with Tero 2545 Niiranen and Juhani Ojala were valuable during the 2546 process of producing this paper. We would also like to 2547 express our sincere gratitude to Derek Blundell for 2548 continuous encouragement while writing this manu2549 script and also for his skills and enthusiasm that made 2550 the GEODE project a success. The reviewers Mark 2551 Barley and Michael Lesher are warmly thanked for 2552 thoughtful comments and suggestions that improved 2553 the manuscript substantially.

\section{References}

\section{5}

2556 Abouchami, W., Boher, M., Michard, A., Albarède, F., 1990. A 2557 major 2.1 Ga old event of mafic magmatism in West Africa. 2558 Journal of Geophysical Research 95, 17605-17629.

2559 Abzalov, M.Z., Both, R.A., 1997. The Pechenga Ni-Cu deposit, 2560 Russia: data on PGE and Au distribution and sulfur isotope 2561 compositions. Mineralogy and Petrology 61, 119-143.

2562 Åhäll, K.-I., Larson, S.-Å., 2000. Growth-related 1.85-1.55 Ga
Peninsula, Russia. In: Cabri, L.J. (Ed.), The Geology, Geochemistry, Mineralogy and Mineral Beneficiation of Platinum-group Elements. CIM Special Volume, vol. 54, pp. 507-546.

Alapieti, T., Kujanpää, J., Lahtinen, J.J., Papunen, H., 1989. The Kemi stratiform chromitite deposit, northern Finland. Economic Geology 84, 1057-1077.

Allen, R.L., Weihed, P., Svenson, S.-Å., 1996a. Setting of Zn-Cu$\mathrm{Au}-\mathrm{Ag}$ massive sulfide deposits in the evolution and facies architecture of a $1.9 \mathrm{Ga}$ marine volcanic arc, Skellefte district, Sweden. Economic Geology 91, 1022-1053.

Allen, R.L., Lundström, I., Ripa, M., Simeonov, A., Christofferson, H., 1996b. Facies analysis of a 1.9 Ga., continental margin, back-arc, felsic caldera province with diverse $\mathrm{Zn}-\mathrm{Pb}-\mathrm{Ag}-(\mathrm{Cu}-$ $\mathrm{Au})$ sulfide and $\mathrm{Fe}$ oxide deposits, Bergslagen region, Sweden. Economic Geology 91, 979-1008.

Allen, R.L., Weihed, P.and the Global VHMS Research Project team, 2002. Global comparison of volcanic-associated massive sulphide districts. In: Blundell, D.J., Neubauer, F., von Quadt, A. (Eds.), The Timing and Location of Major Ore Deposits in an Evolving Orogen. Geological Society, London, Special Publications, vol. 204, pp. 13-37.

Amelin, Y.V., Heaman, L.M., Semenov, V.S., 1995. U-Pb geochronology of layered mafic intrusions in the eastern Baltic Shield: implications for the timing and duration of Palaeoproterozoic continental rifting. Precambrian Research 75, $31-46$.

Anderson, A.T., Morin, M., 1969. Two types of massif anorthosites and their implications regarding the thermal history of the crust. In: Isachsen, Y.W. (Ed.), Origin of Anorthosites and Related Rocks. New York State Museum Sciences Service Memoirs, vol. 18 , pp. 57-69.

Andersson, M., Lie, J.E., Husebye, E.S., 1996. Tectonic setting of post-orogenic granites within SW Fennoscandia based on deep seismic and gravity data. Terra Nova $8,558-566$.

Arndt, N.T., 2003. Komatiites, kimberlites and boninites. Journal of Geophysical Research 108 (B6), 2293, doi: 10.1029/ 2002JB002157.

Arndt, N.T., Albarède, F., Nisbet, E.G., 1997. Mafic and ultramafic magmatism. In: de Wit, M.J., Ashwal, L.D. (Eds.), Greenstone Belts. Oxford Science Publications, Oxford, pp. 233-254.

Ashwal, L.D., 1993. Anorthosites. Springer-Verlag, Berlin, Heidelberg. 422 pp.

BABEL Working Group, 1990. Evidence for Early Proterozoic plate tectonics from seismic reflection profiles in the Baltic Shield. Nature 348, 34-38.

Bailes, A.H., Galley, A.G., 1999. Evolution of the Paleoproterozoic Snow Lake arc assemblage and geodynamic setting for associated volcanic-hosted massive sulphide deposits, Flin Flon Belt, Manitoba, Canada. Canadian Journal of Earth Sciences 36, 1789-1805.

Bark, G., Weihed, P., 2003. The new Lycksele-Storuman gold ore province, northern Sweden; with emphasis on the Early Proterozoic Fäboliden orogenic gold deposit. In: Eliopoulos, D.G., et al., (Eds.), Mineral Exploration and Sustainable Development. Millpress, Rotterdam, pp. 1061-1064.

Barley, M.E., Krapez, B., Groves, D.I., Kerrich, R., 1998. The Late Archaean bonanza: metallogenic and environmental conse- 
quences of the interaction between mantle plumes, lithospheric tectonics and global cyclicity. Precambrian Research 91, 65-90.

Barnes, S.-J., Often, M., 1990. Ti-rich komatiites from northern Norway. Contributions to Mineralogy and Petrology 105, $42-54$.

Barnes, S.-J., Melezhik, V.A., Sokolov, S.V., 2001. The composition and mode of formation of the Pechenga nickel deposits, Kola Peninsula, northwestern Russia. Canadian Mineralogist 39, 447-471.

Barnichon, J.-D., Havenith, H., Hoffer, B., Charlier, R., Jongmans, D., Duchesne, J.C., 1999. The deformation of the Egersund Ogna massif, South Norway: finite element modelling of diapirism. Tectonophysics 303, 109-130.

Barrie, C.T., Hannington, M.D. (Eds.), Volcanic-associated Massive Sulfide Deposits: Processes and Examples in Modern and Ancient Settings. Reviews in Economic Geology, vol. 8, pp. 101-131.

Barton, M.D., Johnson, D.A., 1996. Evaporitic-source model for igneous-related $\mathrm{Fe}$ oxide-( $\mathrm{REE}-\mathrm{Cu}-\mathrm{Au}-\mathrm{U})$ mineralization. Geology 24, 259-262.

Bayanova, T.B., Smolkin, V.F., Levkovich, N.V., 1999. U-Pb geochronology study of Mount Generalskaya layered intrusion, northwestern Kola Peninsula, Russia. Institution of Mining and Metallurgy, Transactions (Section B, Applied Earth Science) 108, 83-90.

Bergman, S., Kübler, L., Martinsson, O., 2001. Description of regional geological and geophysical maps of northern Norrbotten County. Sveriges Geologiska Undersökning, Ba 56 (110 pp.).

Bergman Weihed, J., Bergström, U., Billström, K., Weihed, P., 1996. Geology and tectonic evolution of the Paleoproterozoic Boliden $\mathrm{Au}-\mathrm{Cu}-\mathrm{As}$ deposit, Skellefte District, northern Sweden. Economic Geology 91, 1073-1097.

Berthelsen, A., Marker, M., 1986. 1.9-1.8 Ga old strike-slip megashears in the Baltic Shield, and their plate tectonic implications. Tectonophysics 128, 163-181.

Bibikova, E., Skiöld, T., Bogdanova, S., Gorbatschev, R., Slabunov, A., 2001. Titanite-rutile thermochronometry across the boundary between the Archaean craton in Karelia and the Belomorian Mobile Belt, eastern Baltic Shield. Precambrian Research 105, 315-330.

Billström, K., Martinsson, O., 2000. Links between epigenetic $\mathrm{Cu}-$ Au mineralizations and magmatism/deformation in the Norrbotten county, Sweden. In: Weihed, P., Martinsson, O. (Eds.), Abstract Volume and Field Trip Guidebook, 2nd Annual GEODE-Fennoscandian Shield Field Workshop on Palaeoproterozoic and Archaean Greenstone Belts and VMS Districts in the Fennoscandian Shield 28 August to 1 September, 2000, Gällivare-Kiruna, Sweden, Luleå University of Technology, Research Report, vol. 6, p. 6.

Billström, K., Weihed, P., 1996. Age and provenance of host rocks and ores of the Paleoproterozoic Skellefte District, northern Sweden. Economic Geology 91, 1054-1072.

Bjørlykke, A., Cumming, G.L., Krstic, D., 1990. New isotopic data from davidites and sulfides in the Bidjovagge gold-copper deposit, Finnmark, northern Norway. Mineralogy and Petrology $43,1-21$.
Bogdanova, S.V., Pashkevich, V.B., Buryanov, V.B., Makarenko, I.B., Orlyuk, M.I., Skobelev, V.M., Starostenko, V.I., Legostaeva, O.V., 2004. The 1.80-1.74 Ga gabbro-anorthosite-rapakivi Korosten Pluton in the Ukrainian Shield: a 3-D geophysical reconstruction of deep structure. Tectonophysics $381,5-27$.

Boher, M., Abouchami, W., Michard, A., Albarède, F., Arndt, N.T., 1991. Crustal growth in West Africa at 2.1 Ga. Journal of Geophysical Research 95, 17605-17629.

Broman, C., Martinsson, O., 2000. Fluid inclusions in epigenetic $\mathrm{Fe}-\mathrm{Cu}-\mathrm{Au}$ ores in northern Norrbotten. 2nd Annual GEODEFennoscandian Shield Field Workshop on Palaeoproterozoic and Archaean Greenstone Belts and VMS Districts in the Fennoscandian Shield. Luleå University of Technology, Research Report, vol. 6. 7 pp.

Card, K.D., 1990. A review of the Superior Province of the Canadian Shield, a product of Archean accretion. Precambrian Research 48, 99-156.

Cawthorn, R.G., 1996. Layered igneous rocks. Development in PetrologyElsevier Science, Amsterdam. 531 pp.

Charlier, B., 2005. Fennoscandian Shield - Rogaland anorthosite province. Ore Geology Reviews (this volume).

Charlier, B., Duchesne, J.C., 2003. Whole-rock geochemistry of the Bjerkreim-Sokndal layered series: bearing on crystallization processes of cumulus rocks. NGU Special Publication 9, 35-37.

Cliff, R.A., Rickard, D., Blake, K., 1990. Isotope systematics of the Kiruna magnetite ores, Sweden: Part I. Age of the ore. Economic Geology 85, 1770-1776.

Condie, K.C., 1999. Archean Crustal Evolution. Elsevier Science B.V., Amsterdam. 420 pp.

Condie, K.C., 2004. Precambrian superplume events. In: Eriksson, P.G., Altermann, W., Nelson, D.R., Mueller, W.U., Catuneanu, O. (Eds.), The Precambrian Earth: Tempos and Events. Elsevier Science B.V., Amsterdam, pp. 163-173.

de Wit, M.J., Hart, R.A., Hart, R.J., 1987. The Jamestown ophiolite complex, Barberton mountain belt: a section through $3.5 \mathrm{Ga}$ oceanic crust. Journal of African Earth Sciences 6, 681-730.

Duchesne, J.C., 1996. Liquid ilmenite or liquidus ilmenite: a comment on the nature of ilmenite vein deposit. In: Demaiffe, D. (Ed.), Petrology and Geochemistry of Magmatic Suites of Rocks in the Continental and Oceanic Crusts. ULB-MRAC, Bruxelles, pp. $73-82$.

Duchesne, J.C., 1999. Fe-Ti deposits in Rogaland anorthosites (South Norway): geochemical characteristics and problems of interpretation. Mineralium Deposita 34, 182-198.

Duchesne, J.C., Bingen, B., 2001. The Rogaland anorthosite province: an introduction. In: Duchesne, J.C. (Ed.), The Rogaland Intrusive Massifs, an Excursion Guide, NGU Report, vol. 29. Geological Survey of Norway, pp. 13-24.

Duchesne, J.C., Hertogen, J., 1988. Le magma parental du lopolithe de Bjerkreim-Sokndal (Norvège méridionale). Comptes Rendus de l'Académie des Sciences, Série II 306, 45-48 (Paris).

Duchesne, J.C., Schiellerup, H., 2001. The iron-titanium deposits in the Rogaland anorthosite Province. In: Duchesne, J.C. (Ed.), The Rogaland Intrusive Massifs: an Excursion Guide, NGU Report, vol. 029 , pp. 56-75. 
Duchesne, J.C., Liégeois, J.P., Vander Auwera, J., Longhi, J., 1999. The crustal tongue melting model and the origin of massive anorthosites. Terra Nova 11, 100-105.

Edfelt, Å., Martinsson, O., 2004. The Tjårrojåkka Fe-oxide and $\mathrm{Cu}-$ $\mathrm{Au}$ occurrences, northern Sweden - products of one ore forming event? IAVCEI General Assembly 14-19 November 2004, Pucón, Chile. Abstract volume (CD-ROM).

Edfelt, Å., Martinsson, O., 2003. Fennoscandian Shield - iron oxide copper-gold deposits. Ore Geology Reviews (this volume).

Edfelt, Å., Broman, C., Martinsson, O., 2004. A preliminary fluid inclusion study of the Tjårrojåkka IOCG-occurrence, Kiruna area, northern Sweden. GFF 126, 148.

Eilu, P., Weihed, P., 2003. Fennoscandian Shield - orogenic gold deposits. Ore Geology Reviews (this volume).

Eilu, P., Sorjonen-Ward, P., Nurmi, P., Niiranen, T., 2003. A review of gold mineralization styles in Finland. Economic Geology 98, $1329-1353$

Eilu, P., Pankka, H., Keinänen, V., Kortelainen, V., Niiranen, T., Pulkkinen, E., in press. Characteristics of gold mineralisation in the greenstone belts of northern Finland. Geological Survey of Finland, Special Paper.

Ekdahl, E., 1993. Early Proterozoic Karelian and Svecofennian Formations and the Evolution of the Raahe-Ladoga Ore Zone, Based on the Pielavesi Area, Central Finland. Bulletin, vol. 373. Geological Survey of Finland. 137 pp.

Emslie, R.F., Hamilton, M.A., Thiérault, R.J., 1994. Petrogenesis of a Mid-Proterozoic anorthosite-mangerite-charnockite-granite (AMCG) complex: isotopic and chemical evidence from the Nain plutonic suite. Journal of Geology 102, 539-558.

Ettner, C.D., Bjørlykke, A., Andersen, T., 1993. Fluid evolution and $\mathrm{Au}-\mathrm{Cu}$ genesis along a shear zone: a regional fluid inclusion study of a shear zone-hosted alteration and gold and copper mineralization in the Kautokeino greenstone belt, Finnmark, Norway. Journal of Geochemical Exploration 49, 233-267.

Ettner, D.C., Bjørlykke, A., Andersen, T., 1994. A fluid inclusion and stable isotope study of the Proterozoic Bidjovagge $\mathrm{Au}-\mathrm{Cu}$ deposit, Finnmark, northern Norway. Mineralium Deposita 29, $16-29$.

Foley, S.F., Buhre, S., Jacob, D.E., 2003. Evolution of the Archaean crust by delamination and shallow subduction. Nature 421, $249-252$.

Fram, M.S., Longhi, J., 1992. Phase equilibria of dikes associated with Proterozoic anorthosite complexes. American Mineralogist 77, 605-616.

Francis, D., Ludden, J., Johnstone, R., Davis, W., 1999. Picrite evidence for more Fe in Archaean mantle reservoirs. Earth and Planetary Science Letters 167, 197-213.

Frietsch, R., 1977. The iron ore deposits in Sweden. In: Zitman, A. (Ed.), The Iron Ore Deposits of Europe and Adjacent Areas. Bundesanstalt für Geowissenschaft und Rohstoffe, Hannover, pp. 279-293.

Frietsch, R., Tuisku, P., Martinsson, O., Perdahl, J.-A., 1997. Cu$\mathrm{Au}$ ) and $\mathrm{Fe}$ ore deposits associated with $\mathrm{Na}-\mathrm{Cl}$ metasomatism in Early Proterozoic rocks of northern Fennoscandia: a new metallogenic province. Ore Geology Reviews 12, 1-34.
Gaál, G., 1972. Tectonic control of some Ni-Cu deposits in Finland. In: Gill, J.E. (Ed.), Proceedings, International Geological Congress, 24th session, Montreal 1972: Section 4, Mineral Deposits, pp. $215-224$.

Gaál, G., 1982. Proterozoic tectonic evolution and Late Svecokarelian plate deformation of the central Baltic Shield. Geologische Rundschau 71, 158-170.

Gaál, G., 1985. Nickel metallogeny related to tectonics. In: Papunen, H., Gorbunov, G.I. (Eds.), Nickel-Copper Deposits of the Baltic Shield and Scandinavian Caledonides, Bulletin, vol. 333. Geological Survey of Finland, pp. 143-155.

Gaál, G., 1990. Tectonic styles of Early Proterozoic ore deposition in the Fennoscandian Shield. Precambrian Research 46, $83-114$.

Gaál, G., Gorbatschev, R., 1987. An outline of the Precambrian evolution of the Baltic Shield. Precambrian Research $35,15-52$.

Geological Survey of Finland,, 2004. Ore Deposit Data Base. http://www.gsf.fi/explor/.

Goldfarb, R.J., Groves, D.I., Gardoll, S., 2001. Orogenic gold and geologic time: a global synthesis. Ore Geology Reviews $18,1-75$.

Goldstein, S.L., Arndt, N.T., Stallard, R.F., 1997. The history of a continent from $\mathrm{Sm}-\mathrm{Nd}$ isotopes in Orinoco basin river sediments and $\mathrm{U}-\mathrm{Pb}$ ages of zircons from Orinoco river sand. Chemical Geology 139, 271-298.

Gorbatschev, R., Bogdanova, S., 1993. Frontiers in the Baltic Shield. Precambrian Research 64, 3-21.

Gorbunov, G.I., Zagorodny, V.G., Robonen, W.I., 1985. Main features of the geological history of the Baltic Shield and the epochs of ore formation. In: Papunen, H., Gorbunov, G.I. (Eds.), Nickel-Copper Deposits of the Baltic Shield and Scandinavian Caledonides, Bulletin, vol. 333. Geological Survey of Finland, pp. 17-41.

Green, A.H., Melezhik, V.A., 1999. Geology of the Pechenga ore deposits; a review with comments on ore forming processes. In: Keays, R.R., Lesher, C.M., Lightfoot, P.C., Farrow, C.E.G. (Eds.), Dynamic Processes in Magmatic Ore Deposits and their Application to Mineral Exploration. Geological Association of Canada, Short Course Notes, vol. 13, pp. 287-328.

Grönholm, P., 1999. The mesothermal Saattopora copper-gold deposit in the Palaeoproterozoic Central Lapland greenstone belt, Northern Finland. In: Cook, N.J., Sundblad, K. (Eds.), Precambrian Gold in the Fennoscandian and Ukrainian Shields and Related Areas. Gold '99 Trondheim, Norway, 4-6 May 1999. Geological Survey of Norway, Trondheim, p. 83.

Groves, D.I., Goldfarb, R.J., Gebre-Mariam, M., Hagemann, S., Robert, F., 1998. Orogenic gold deposits: a proposed classification in the context of their crustal distribution and relationship to other gold deposit types. Ore Geology Reviews 13, $1-28$.

Halkoaho, T., Pietikäinen, K., 1999. Ni and Au prospects of the Kuhmo and Suomussalmi greenstone belts. In: Papunen, H., Eilu, P. (Eds.), Geodynamic Evolution and Metallogeny of the Central Lapland, Kuhmo and Suomussalmi Greenstone Belts, Finland. Publication, vol. 42. Institute of Geology and Mineralogy, University of Turku, pp. 60-63. 
Halkoaho, T., Liimatainen, J., Papunen, H., Välimaa, J., 2000. Exceptionally $\mathrm{Cr}$-rich basalts in the komatiitic volcanic association of the Archaean Kuhmo greenstone belt, eastern Finland. Mineralogy and Petrology 70, 105-120.

Hallberg, A., 1994. The Enåsen gold deposit, central Sweden: 1. A Paleoproterozoic high sulphidation epithermal gold mineralization. Mineralium Deposita 29, 150-162.

Hamilton, M.A., Ryan, A.B., Emslie, R.F., Ermanovics, I.F., 1998. Identification of Paleaoproterozoic anorthosititic and monzonitic rocks in the vicinity of the Mesoproterozoic Nain plutonic suite, Labrador: U-Pb evidence. Radiogenic Age and Isotopic Studies, Current Research 1998-F, Report, vol. 11. Geological Survey of Canada, pp. 23-40.

Hanski, E.J., 1992. Petrology of the Pechenga ferropicrites and cogenetic Ni-bearing gabbro-wehrlite intrusions, Kola Peninsula, Russia. Geological Survey Finland Bulletin 367 (192 pp.).

Hanski, E.S., 1997. The Nuttio serpentinite belt, central Lapland: an example of Paleoproterozoic ophiolitic mantle rocks in Finland. Ofioliti 22, 35-46.

Hanski, E.S., Smolkin, V.F., 1989. Pechenga ferropicrites and other Early Proterozoic picrites in the eastern part of the Baltic Shield. Precambrian Research 45, 63-82.

Hanski, E., Huhma, H., Vaasjoki, M., 2001a. Geochronology of northern Finland: a summary and discussion. Special Paper, vol. 33. Geological Survey of Finland, pp. 255-279.

Hanski, E., Huhma, H., Rastas, P., Kamenetsky, V.S., 2001b. The palaeoproterozoic komatiite-picrite association of Finnish Lapland. Journal of Petrology 42, 855-876.

Haughton, D.R., Roeder, P.L., Skinner, B.J., 1974. Solubility of sulfur in mafic magmas. Economic Geology 69, 451-467.

Hedström, P., Simeonov, A., Malmström, L., 1989. The Zinkgruvan ore deposit, south-central Sweden: a Proterozoic, proximal Zn$\mathrm{Pb}-\mathrm{Ag}$ deposit in distal volcanic facies. Economic Geology 84, $1235-1261$.

Helovuori, O., 1979. The geology and zinc-copper deposits of the Pyhäsalmi-Pielavesi district, Finland. Economic Geology 74, 1084-1101.

Herzberg, C., 1992. Depth and degree of melting of komatiite. Journal of Geophysical Research 97, 4521-4540.

Hietanen, A., 1975. Generation of potassium poor magmas in the northern Sierra Nevada and the Svecofennian of Finland. Journal of Research, US Geological Survey 3, 631-645.

Hill, R.E.T., 2001. Komatiite volcanology, volcanological setting and primary geochemical properties of komatiite-associated nickel deposits. Geochemistry: Exploration, Environment, Analysis $1,365-381$.

Hiltunen, A., 1982. The Precambrian Geology and Skarn Iron Ores of the Rautuvaara Area, Northern Finland. Bulletin, vol. 318. Geological Survey of Finland. 133 pp.

Hitzman, M.W., 2000. Iron oxide- $\mathrm{Cu}-\mathrm{Au}$ deposits: what, where, when, and why. In: Porter, T.M. (Ed.), Hydrothermal Iron Oxide Copper-Gold and Related Deposits: A Global Perspective. Australian Mineral Foundation, Adelaide, pp. 9-25.

Hitzman, M.W., Oreskes, N., Einaudi, M.T., 1992. Geological characteristics and tectonic setting of Proterozoic iron oxide (Cu-U-Au-REE) deposits. Precambrian Research 58, $241-287$.
Huhma, H., Cliff, R.A., Perttunen, V., Sakko, M., 1990. Sm-Nd and $\mathrm{Pb}$ isotopic study of mafic rocks associated with Early Proterozoic continental rifting; the Perapohja schist belt in northern Finland. Contributions to Mineralogy and Petrology 104, 369-379.

Huhma, H., Mänttäri, I., Vaasjoki, M., 1999. Dating the Finnish Archaean greenstone belts - isotope geology. In: Papunen, H., Eilu, P. (Eds.), Geodynamic Evolution and Metallogeny of the Central Lapland, Kuhmo and Suomussalmi Greenstone Belts, Finland. Joint Field Excursion and Workshop of GEODE, 1116. September 1999 , pp. $72-74$. abstracts.

Huhma, H., Mutanen, T., Whitehouse, M., 2004. Oldest rocks of the Fennoscandian Shield: the 3.5 Ga Siurua trondhjemite gneiss in the Archaean Pudasjärvi granulite belt, Finland. GFF 126, 10.

Huhtala, T., 1979. The geology and zinc-copper deposits of the Pyhäsalmi-Pielavesi District, Finland. Economic Geology 74, 1069-1083.

Huppert, H.E., Sparks, S.J., Turner, J.S., Arndt, N.T., 1984. Emplacement and cooling of komatiite lavas. Nature 309, 19-22.

Inkinen, O., 1979. Copper, zinc, and uranium occurrences at Pahtavuoma in the Kittilä greenstone complex, northern Finland. Economic Geology 74, 1153-1165.

Juhlin, C., Elming, S.-Å., Mellqvist, C., Öhlander, B., Weihed, P., Wikström, A., 2002. Crustal reflectivity near the ArchaeanProterozoic boundary in northern Sweden and the implications for the tectonic evolution of the area. Geophysical Journal International 150, 180-197.

Kähkönen, Y., Lahtinen, R., Nironen, M., 1994. Palaeoproterozoic supracrustal belts in southwestern Finland. Guide, vol. 37. Geological Survey of Finland, pp. 43-47.

Karhu, J.A., 1993. Paleoproterozoic Evolution of the Carbon Isotope Ratios of Sedimentary Carbonates in the Fennoscandian Shield. Bulletin, vol. 371. Geological Survey of Finland. $87 \mathrm{pp}$.

Karsten, J.L., Klein, E.M., Sherman, S.B., 1996. Subduction zone geochemical characteristics in ocean ridge basalts from the southern Chile ridge: implications of modern ridge subduction systems for the Archean. Lithos 37, 143-161.

Kilpeläinen, T., 1998. Evolution and 3D Modelling of Structural and Metamorphic Patterns of the Palaeoproterozoic Crust in the Tampere-Vammala Area, Southern Finland. Bulletin, vol. 397. Geological Survey of Finland. 124 pp.

Kimura, G., Ludden, J.N., Desrochers, J.-P., Hori, R., 1993. A model of ocean-crust accretion for the Superior Province, Canada. Lithos 30, 337-355.

Koark, H.J., 1962. Zur Altersstellung und Entstehung der Sulfiderze vom Typus Falun. Geologische Rundschau 52, 123-146.

Koistinen, T., Stephens, M.B., Bogatchev, V., Nordgulen, Ø., Wennerström, M., Korhonen, J. (Eds.), 2001. Geological Map of the Fennoscandian Shield, Scale 1:2 000 000. Geological surveys of Finland, Norway and Sweden and the North-West Department of Natural Resources of Russia. ISBN: 951-690-810-1.

Kontinen, A., 1998. The nature of the serpentinites, associated dolomite-skarn-quartz rocks and massive $\mathrm{Co}-\mathrm{Cu}-\mathrm{Zn}$ sulphide ores in the Outokumpu area, eastern Finland. In: Hanski, E., Vuollo, J. (Eds.), International Ophiolite Symposium and Field Excursion - Generation and Emplacement of Ophiolites 
Through Time. August 10-15, 1998, University of Oulu, Oulu, Finland. Abstracts - Excursion Guide. Special Paper, vol. 26. Geological Survey of Finland, p. 33.

Kontinen, A., Paavola, J., Lukkarinen, H., 1992. K-Ar ages of hornblende and biotite from Late Archaean rocks of eastern Finland - interpretation and discussion of tectonic implications. Bulletin, vol. 365. Geological Survey of Finland, pp. 1-31.

Kontoniemi, O., 1998. Geological setting and characteristics of the Palaeoproterozoic tonalite-hosted Osikonmäki gold deposit, southeastern Finland. Special Paper, vol. 25. Geological Survey of Finland, pp. 39-80.

Korja, A., 1995. Structure of the Svecofennian crust - growth and destruction of the Svecofennian orogen. Ph.D. Thesis, Institute of Seismology, University of Helsinki, Report S-31. 36 p.

Korja, A., Korja, T., Luostro, U., Heikkinen, P., 1993. Seismic and geoelectric evidence for collisional and extensional events in the Fennoscandian Shield - implications for Precambrian crustal evolution. Tectonophysics 219, 129-152.

Korsman, K., Koistinen, T., Kohonen, J., Wennerström, M., Ekdahl, E., Honkamo, M., Idman, H., Pekkala, Y. (Eds.), 1997. Suomen kallioperäkartta - Berggrundskarta Över Finland - Bedrock Map of Finland 1:1 000 000. Geological Survey of Finland, Espoo, Finland.

Korsman, K., Korja, T., Pajunen, M., Vinansalo, P.GGT/SVEKA Working Group, 1999. The GGT/SVEKA Transect structure and evolution of the continental crust in the Paleoproterozoic Svecofennian orogen in Finland. International Geological Reviews 41, 287-333.

Korvuo, E., 1997. The Saattopora gold ore and the Pahtavuoma Cu$\mathrm{Zn}-\mathrm{U}$ occurrences in the Kittilä region, northern Finland. In: Korkiakoski, E., Sorjonen-Ward, P. (Eds.), Research and Exploration - Where do they Meet? 4th Biennial SGA Meeting, August 11-13, 1997, Turku, Finland. Excursion Guidebook B1: Ore Deposits of Lapland in Northern Finland and Sweden. Guide, vol. 43. Geological Survey of Finland, pp. 21-25.

Kousa, J., Marttila, E., Vaasjoki, M., 1994. Petrology, geochemistry and dating of Paleoproterozoic metavolcanic rocks in the Pyhäjärvi area, central Finland. In: Nironen, M., Kähkönen, Y. (Eds.), Geochemistry of Proterozoic Supracrustal Rocks in Finland. Special Paper, vol. 19. Geological Survey of Finland, pp. 7-27.

Kurki, J., Papunen, H., 1985. Geology and nickel-copper deposits of the Kianta area, Suomussalmi. In: Papunen, H., Gorbunov, G.I. (Eds.), Nickel-Copper Deposits of the Baltic Shield and Scandinavian Caledonides. Bulletin, vol. 333. Geological Survey of Finland, pp. 155-164.

Lahtinen, R., 1994. Crustal Evolution of the Svecofennian and Karelian Domains during 2.1-1.79 Ga, with Special Emphasis on the Geochemistry and Origin of 1.93-1.91 Ga Gneissic Tonalites and Associated Supracrustal Rocks in the Rautalampi Area, Central Finland. Bulletin, vol. 378. Geological Survey of Finland. 128 pp.

Lahtinen, R., Huhma, H., 1997. Isotopic and geochemical constraints on the evolution of the 1.93-1.79 Ga Svecofennian crust and mantle in Finland. Precambrian Research 82, 13-34.

Lahtinen, R., Korja, A., Nironen, M., 2003. Paleoproterozoic orogenic evolution of the Fennoscandian Shield at 1.92-1.77 Ga with notes on the metallogeny of $\mathrm{FeOx}-\mathrm{Cu}-\mathrm{Au}$, VMS, and orogenic gold deposits. In: Eliopoulos, D.G., et al., (Eds.), Mineral Exploration and Sustainable Development. Millpress, Rotterdam, pp. 1057-1060.

Lahtinen, R., Korja, A., Nironen, M., 2004. Paleoproterozoic orogenic evolution of the Fennoscandian Shield at 1.92-1.77 Gathe formation of a supercontinent. GFF 126, 27.

Lahtinen, R., Korja, A., Nironen, M., 2005. Paleoproterozoic tectonic evolution. In: Lehtinen, M., Nurmi, P.A., Rämö, O.T. (Eds.), Precambrian Geology of Finland - Key to the Evolution of the Fennoscandian Shield. Elsevier Science, B.V., Amsterdam, pp. 481-532.

Lehtonen, M., Airo, M.-L., Eilu, P., Hanski, E., Kortelainen, V., Lanne, E., Manninen, T., Rastas, P., Räsänen, J., Virransalo, P., 1998. The Stratigraphy, Petrology and Geochemistry of the Kittilä Greenstone Area, Northern Finland: a Report of the Lapland Volcanite Project. Report of Investigation, vol. 140. Geological Survey of Finland. 144 pp. (in Finnish with English summary).

Lesher, C.M., 1989. Komatiite-associated nickel sulfide deposits. In: Whitney, J.A., Naldrett, A.J. (Eds.), Ore Deposition Associated with Magmas. Reviews in Economic Geology, vol. 4, pp. $45-102$.

Lesher, C.M., Arndt, N.T., Groves, D.I., 1984. Genesis of komatiiteassociated nickel sulfide deposits at Kambalda, Western Australia: a distal volcanic model. In: Buchanan, D.L., Jones, M.L. (Eds.), Sulfide Deposits in Mafic and Ultramafic Rocks. Institute of Mining and Metallurgy, London, pp. 70-80.

Lindblom, S., Broman, C., Martinsson, O., 1996. Magmatic-hydrothermal fluids in the Pahtohavare $\mathrm{Cu}-\mathrm{Au}$ deposit in greenstone at Kiruna, Sweden. Mineralium Deposita 31, 307-318.

Lindskog, L., 2001. Relationships between Fe-oxide $\mathrm{Cu} / \mathrm{Au}$ deposits at Gruvberget-Kiruna District, northern Sweden. Unpublished B.Sc. Thesis, James Cook University, Townsville, Australia. 123 pp.

Lindsley, D.H., 2003. Do Fe-Ti oxide magmas exist? Geology: yes; experiments: no! NGU Special Publication 9, 34-35.

Lobach-Zhuchenko, S.B., Chekulaev, V.P., Sergeev, S.A., Levchenkov, O.A., Krylov, I.N., 1993. Archaean rocks from southeastern Karelia (Karelian granite-greenstone terrain). Precambrian Research 62, 375-397.

Longhi, J., Fram, M.S., Vander Auwera, J., Montieth, J.N., 1993. Pressure effects, kinetics, and rheology of anorthositic and related magmas. American Mineralogist 78, 1016-1030.

Longhi, J., Vander Auwera, J., Fram, M., Duchesne, J.C., 1999. Some phase equilibrium constraints on the origin of Proterozoic (Massif) anorthosites and related rocks. Journal of Petrology 40, $339-362$.

Lundqvist, T., Vaasjoki, M., Persson, P.-O., 1998. U-Pb ages of plutonic and volcanic rocks in the Svecofennian Bothnian Basin, central Sweden, and their implications for the Palaeoproterozoic evolution of the basin. GFF 120, 357-363.

Lundström, I., 1987. Lateral variations in supracrustal geology within the Swedish part of the southern Svecokarelian volcanic belt. Precambrian Research 35, 353-365.

Luukkonen, E., 1992. Late Archaean and Early Proterozoic structural evolution in the Kuhmo-Suomussalmi terrain, east- 
ern Finland. Annales Universitatis Turkuensis Series A, II 78, $1-37$.

Mäki, T., 1986. Lithogeochemistry of the Pyhäsalmi zinc-copperpyrite deposit, Finland. Prospecting in Areas of Glaciated Terrain. Symposium Proceedings, Sept. 1-2, 1986 Kuopio, Finland. Institution of Mining and Metallurgy, London, pp. 69-82.

Mäkinen, J., 1987. Geochemical Characteristics of Svecokarelidic Mafic-Ultramafic Intrusions Associated with $\mathrm{Ni}-\mathrm{Cu}$ Occurrences in Finland. Bulletin, vol. 342. Geological Survey of Finland. 109 pp.

Makkonen, H.V., 1996. 1.9 Ga Tholeiitic Magmatism and Related $\mathrm{Ni}-\mathrm{Cu}$ Deposition in the Juva Area, SE Finland. Bulletin, vol. 386. Geological Survey of Finland. (128 pp.)

Manninen, T., Huhma, H., 2001. A new U-Pb zircon constraint from the Salla schist belt, northern Finland. Special Paper, vol. 33. Geological Survey of Finland, pp. 201-208.

Mänttäri, I., 1995. Lead Isotope Characteristics of Epigenetic Gold Mineralization in the Palaeoproterozoic Lapland Greenstone Belt, Northern Finland. Bulletin, vol. 381. Geological Survey of Finland. $70 \mathrm{pp}$.

Marshall, B., Smith, J.V., Mancini, F., 1995. Emplacement and implications of peridotite-hosted leucocratic dykes, Vammala Mine, Finland. Geologiska Föreningens i Stockholm Förhandlingar 117, 199-205.

Martinsson, O., 1997. Tectonic setting and metallogeny of the Kiruna greenstones. Ph.D. Thesis, Luleå University of Technology, Sweden, 19. 19 pp.

Martinsson, O., 2001. Diversity and character of apatite iron ores and their relation to epigenetic $\mathrm{Cu}-\mathrm{Au}$ deposits in the Norrbotten $\mathrm{Fe}-\mathrm{Cu}-\mathrm{Au}$ province, northern Sweden. GSA Annual Meeting, Special session: Iron-Oxide(-Copper-Gold) Systems Deposit Studies to Global Context, Boston 4 November 2001, GSA Website Abstracts with Programs, vol. 33, http://gsa. confex.com/gsa/2001AM/finalprogram/abstract_26785.htm.

Martinsson, O., Weihed, P., 1999. Metallogeny of juvenile Palaeoproterozoic volcanic arcs and greenstone belts in rifted Archaean crust in the northern part of Sweden, Fennoscandian Shield. In: Stanley, C.J., et al., (Eds.), Mineral Deposits: Processes to Processing. A.A. Balkema, Rotterdam, pp. 1329-1332.

Martinsson, O., Hallberg, A., Broman, C., Godin-Jonasson, L., Kisiel, T., Fallick, T., 1997. Viscaria - a syngenetic exhalative $\mathrm{Cu}$-deposit in the Palaeoproterozoic Kiruna greenstones. In: Martinsson, O., 1997. Tectonic setting and metallogeny of the Kiruna greenstones. Ph.D. Thesis, Luleå University of Technology, Sweden, 19, ISSN:1402.

Melezhik, V.A., 1996. The geology and ore deposits of the Pechenga greenstone belt. IGCP Project 336, Field Conference And Symposium, Rovaniemi, Finland, August 18-30, 1996; Field Trip Guidebook: Part III. Geological Survey of Norway, Trondheim. $91 \mathrm{pp}$.

Melezhik, V.A., Hudson-Edwards, K.A., Green, A.H., Grinenko, L.N., 1994. The Pechenga area, Russia. 2. Nickel-copper deposits and related rocks. Transactions, Institute of Mining and Metallurgy (Section B, Applied Earth Science) 103, 146-161.

Melezhik, V.A., Grinenko, L.N., Fallick, A.E., 1998. 2000-Ma sulfide concretions from the "Productive" Formation of the Pechenga greenstone belt, NW Russia: genetic history based on morphological and isotopic evidence. Chemical Geology 148, 61-94.

Menard, T., Ridgway, C.K., Stowell, H.H., Lesher, C.M., 1999. Geochemistry and textures of metasomatic combs and orbicules in ultramafic rocks, Namew Lake, Manitoba. Canadian Mineralogist 37, 431-442.

Mints, M.Y., Berzin, R.G., Zamozhnyaya, N.G., Stupak, Y.M., Suleimanov, A.K., Konilov, A.N., Babarina, I.I., 2001. Collision structures in the Early Precambrian crust of the eastern Baltic Shield: a geological interpretation of seismic data along profile 4B. Doklady Earth Sciences 379, 515-520.

Mitrofanov, F.P., Bayanova, T.B., 1999. Duration and timing of orebearing Paleoproterozoic intrusions of Kola Province. In: Stanley, C.J., et al., (Eds.), Mineral Deposits: Processes to Processing. A.A. Balkema, Rotterdam, pp. 1275-1278.

Mutanen, T., 1997. Geology and Ore Petrology of the Akanvaara and Koitelainen Mafic Layered Intrusions and the KeivitsaSatovaara Layered Complex, Northern Finland. Bulletin, vol. 395. Geological Survey of Finland. 233 pp.

Naldrett, A.J., 1989. Magmatic Sulfide Deposits. Oxford Monographs on Geology and Geophysics, vol. 14. Oxford University Press. 186 pp.

Naldrett, A.J., 2001. World-class Ni-Cu-PGE deposits: key factors in their genesis. Mineralium Deposita 34, 227-240.

Nelson, D.R., 2004. Episodic crustal growth during catastrophic global-scale mantle overturn events. In: Eriksson, P.G., Altermann, W., Nelson, D.R., Mueller, W.U., Catuneanu, O. (Eds.), The Precambrian Earth: Tempos and Events. Elsevier Science B.V., Amsterdam, pp. 180-183.

Niiranen, T., Hanski, E., Eilu, E., 2003. General geology, alteration, and iron deposits in Palaeoproterozoic Misi region, northern Finland. Bulletin, vol. 75. Geological Society of Finland, pp. 69-92.

Nironen, M., 1997. The Svecofennian Orogen: a tectonic model. Precambrian Research 86, 21-44.

Nisbet, E.G., Cheadle, M.J., Arndt, N.T., Bickle, M.J., 1993. Constraining the potential temperature of the Archaean mantle: a review of the evidence from komatiites. Lithos 30, 291-307.

Nuutilainen, J., 1968. On the Geology of the Misi Iron Ore Province, Northern Finland. Annales Academiae Scientiarum Fennicae, Series A III, Geologica-Geographica. 98 pp.

Nyström, J.O., Henriquez, F., 1994. Magmatic features of iron ores of the Kiruna type in Chile and Sweden: ore textures and magnetite geochemistry. Economic Geology 89, 820-839.

O’Brien, H.E., Nurmi, P.A., Karhu, J.A., 1993. Oxygen, hydrogen and strontium isotopic compositions of gold mineralization in the Late Archaean Hattu Schist Belt, eastern Finland. In: Nurmi, P., Sorjonen-Ward, P. (Eds.), Geological Development, Gold Mineralization and Exploration Methods in the Late Archaean Hattu Schist Belt, Ilomantsi, Eastern Finland. Special Paper, vol. 17. Geological Survey of Finland, pp. 291-306.

Paludan, J., Hansen, U.B., Olesen, N.Ø., 1994. Structural evolution of the Precambrian Bjerkreim-Sokndal intrusion, South Norway. Norsk Geologisk Tidsskrift 74, 185-198.

Pankka, H., 1992. Geology and mineralogy of Au-Co-U deposits in the Proterozoic Kuusamo volcanosedimentary belt, north- 
eastern Finland. Ph.D. Thesis, Michigan Technological University. 233 pp.

Papunen, H., 1971. Sulfide mineralogy of the Kotalahti and Hitura nickel-copper ores, Finland. Annales Academiae Scientarum Fennicae, Series A, III (109 pp.).

Papunen, H., 1989. Platinum-group elements in metamorphosed $\mathrm{Ni}-\mathrm{Cu}$ deposits in Finland. In: Prendergast, M.D., Jones, M.J. (Eds.), Magmatic Sulphides - the Zimbabwe Volume. Institution of Mining and Metallurgy, London, pp. 165-176.

Papunen, H., 2003. Ni-Cu sulfide deposits in mafic-ultramafic orogenic intrusions. Examples from the Svecofennian areas, Finland. In: Eliopoulos, D.G., et al., (Eds.), Mineral Exploration and Sustainable Development. Millpress, Rotterdam, pp. 551-554.

Papunen, H., Gorbunov, G.I. (Eds.), Nickel-Copper Deposits of the Baltic Shield and Scandinavian Caledonides. Bulletin, vol. 333. Geological Survey of Finland. 394 pp.

Papunen, H., Vorma, A., 1985. Nickel deposits in Finland, a review. In: Papunen, H., Gorbunov, G.I. (Eds.), Nickel-Copper Deposits of the Baltic Shield and Scandinavian Caledonides, Bulletin, vol. 333. Geological Survey of Finland, pp. 123-143.

Papunen, H., Halkoaho, T., Tulenheimo, T., Liimatainen, J., 1998. Excursion to the Kuhmo greenstone belt. In: Hanski, E., Vuollo, J. (Eds.), International Ophiolite Symposium and Field Excursion; Generation and Emplacement of Ophiolites through Time; Abstracts, Excursion Guide, Special Paper, vol. 26. Geological Survey of Finland, pp. 91-106.

Parák, T., 1975. The origin of the Kiruna iron ores. Sveriges Geologiska Undersökning C 709 (209 pp.).

Parman, S., Grove, T.L., Dann, J., 2001. The production of Barberton komatiites in an Archean subduction zone. Geophysical Research Letters 28, 2513-2516.

Peltonen, P., 1990. Metamorphic olivine in picritic metavolcanics from Southern Finland. Bulletin, vol. 62. Geological Society of Finland, pp. 99-114.

Peltonen, P., 1995a. Petrogenesis of ultramafic rocks in the Vammala Nickel Belt: implications for crustal evolution of the Early Proterozoic Svecofennian arc terrane. Lithos 34, 253-274.

Peltonen, P., 1995b. Crystallization and re-equilibration of zoned chromite in ultramafic cumulates, Vammala Ni-Belt, southwestern Finland. Canadian Mineralogist 33, 521-535.

Peltonen, P., 2005. Svecofennian mafic-ultramafic intrusions. In: Lehtinen, M., Nurmi, P.A., Rämö, O.T. (Eds.), The Precambrian Bedrock of Finland - Key to the Evolution of the Fennoscandian Shield. Elsevier Science B.V., Amsterdam, pp. 411-446.

Perring, C.S., Pollard, P.J., Dong, G., Nunn, A.J., Blake, K.L., 2000. The Lightning Creek Sill Complex, Cloncurry District, Northwestern Queensland: a source of fluids for the $\mathrm{Fe}$ oxide $\mathrm{Cu}-\mathrm{Au}$ mineralization and sodic-calcic alteration. Economic Geology 95, 1037-1089.

Philpotts, A.R., 1967. Origin of certain iron-titanium oxide and apatite rocks. Economic Geology 62, 303-315.

Piirainen, P., 1988. The geology of the Archaean greenstone-granitoid terrain in Kuhmo, eastern Finland. In: Marttila, E. (Ed.), Archaean Geology of the Fennoscandian Shield; Proceedings of a Finnish-Soviet Symposium. Special Paper, vol. 4. Geological Survey of Finland, pp. 39-51.
Porter, T.M., 2000. Hydrothermal iron-oxide copper-gold and related ore deposits. In: Porter, T.M. (Ed.), Hydrothermal Iron Oxide Copper-Gold and Related Deposits: A Global Perspective. Australian Mineral Foundation, Adelaide, pp. 3-5.

Poutiainen, M., Grönholm, P., 1996. Hydrothermal fluid evolution of the Paleoproterozoic Kutemajärvi gold telluride deposit, Southwest Finland. Economic Geology 91, 1335-1353.

Poutiainen, M., Partamies, S., 2003. Fluid inclusion characteristics of auriferous quartz veins in Archean and Paleoproterozoic greenstone belts of eastern and southern Finland. Economic Geology 98, 1355-1369.

Puchtel, I.S., Hofmann, A.W., Amelin, Y.V., Garbe Schonberg, C.D., Samsonov, A.V., Shchipansky, A.A., 1999. Combined mantle plume-island arc model for the formation of the $2.9 \mathrm{Ga}$ Sumozero-Kenozero greenstone belt, SE Baltic Shield: isotope and trace element constraints. Geochimica et Cosmochimica Acta 63, 3579-3595.

Puustinen, K., Saltikoff, B., Tontti, M., 1995. Distribution and Metallogenic Types of Nickel Deposits in Finland. Report of Investigation, vol. 132. Geological Survey of Finland. 38 pp.

Räsänen, J., Huhma, H., 2001. U-Pb datings in the Sodankylä schist area, central Finnish Lapland. In: Vaasjoki, M. (Ed.), Radiometric Age Determinations from Finnish Lapland and their Bearing on the Timing of Precambrian Volcano-Sedimentary Sequences. Special Paper, vol. 33. Geological Survey of Finland, pp. $153-188$.

Rasilainen, K., 1991. Geochemistry and wall rock alteration at the Kangasjärvi massive sulphide deposit, Central Finland. In: Autio, S. (Ed.), Current Research 1989-1990. Special Paper, vol. 12. Geological Survey of Finland, pp. 107-110.

Rastas, P., Huhma, H., Hanski, E., Lehtonen, M.I., Härkönen, I., Kortelainen, V., Mänttäri, I., Paakkola, J., 2001. U-Pb isotopic studies on the Kittilä greenstone area, central Lapland, Finland. In: Vaasjoki, M. (Ed.), Radiometric Age Determinations from Finnish Lapland and their Bearing on the Timing of Precambrian Volcano-sedimentary Sequences. Special Paper, vol. 33. Geological Survey of Finland, pp. 95-141.

Rickard, D. (Ed.), 1986. The Skellefte Field, Sveriges Geologiska Undersökning $\mathrm{Ca}$, vol. 62.54 pp.

Roberts, M., 2002. Architecture, geochemistry and dynamics of Palaeoproterozoic seafloor hydrothermal systems preserved in a high grade metamorphic terrane, Vihanti-Pyhäsalmi District, Central Finland. Ph.D. Thesis, James Cook University, Townsville, Australia. $407 \mathrm{pp}$.

Robins, B., Wilson, J.R., 2001. The Bjerkreim-Sokndal layered intrusion. In: Duchesne, J.C. (Ed.), The Rogaland Intrusive Massifs, an Excursion Guide. NGU Report, vol. 29. Geological Survey of Norway, pp. 35-37.

Romer, R.L., Martinsson, O., Perdahl, J.-A., 1994. Geochronology of the Kiruna iron ores and hydrothermal alterations. Economic Geology 89, 1249-1261.

Russell, M.J., Arndt, N.T., 2005. Geodynamic and metabolic cycles in the Hadean. Biogeosciences 1, 591-624.

Rutland, R.W.R., Skiöld, T., Page, R.W., 2001. Age of deformation episodes in the Palaeoproterozoic domain of northern Sweden, and evidence for a pre-1.9 Ga crustal layer. Precambrian Research 112, 239-259. 
Schärer, U., Wilmart, E., Duchesne, J.C., 1996. The short duration and anorogenic character of anorthosite magmatism: $\mathrm{U}-\mathrm{Pb}$ dating of the Rogaland complex, Norway. Earth and Planetary Science Letters 139, 335-350.

Schiellerup, H., Lambert, D.D., Prestvik, T., Robins, B., McBride, J.S., Larsen, R.B., 2000. Re-Os isotopic evidence for a lower crustal origin of massif-type anorthosites. Nature 405, 781-784.

Scoates, J.S., Chamberlain, K.R., 1997. Orogenic to post-orogenic origin for the 1.76 Ga Horse Creek anorthosite complex, Wyoming, USA. Journal of Geology 105, 331-343.

Slabunov, A.I., Bibikova, E.V., 2001. The meso- and neoArchaean of the Karelian and Belomorian provinces, Baltic Shield (geology, isotope geochemistry and geodynamic reconstructions). In: Cassidy, K.F., Dunphy, J.M., van Kranendonk, M.J. (Eds.), Fourth International Archaean Symposium; Extended Abstracts. Australian Geological Survey Organisation Record, pp. 359-361.

Sleep, N.H., Windley, B.F., 1982. Archaean plate tectonics: constraints and inferences. Journal of Geology 90, 363-379.

Sorjonen-Ward, P., 1993. An overview of structural evolution and lithic units within and intruding the Late Archaean Hattu schist belt, Ilomantsi, eastern Finland. In: Nurmi, P., Sorjonen-Ward, P. (Eds.), Geological Development, Gold Mineralization and Exploration Methods in the Late Archaean Hattu Schist Belt, Ilomantsi, Eastern Finland. Special Paper, vol. 17. Geological Survey of Finland, pp. 9-102.

Sorjonen-Ward, P., Luukkonen, E., 2005. Archaean rocks. In: Lehtinen, M., Nurmi, P.A., Rämö, O.T. (Eds.), Precambrian Geology of Finland - Key to the Evolution of the Fennoscandian Shield. Elsevier Science, B.V., Amsterdam, pp. 19-99.

Sorjonen-Ward, P., Nurmi, P., Härkönen, I., Pankka, H., 1992. Epigenetic gold mineralization and tectonic evolution of a Lower Proterozoic greenstone terrain in the northern Fennoscandian (Baltic) Shield. In: Sarkar, S.C. (Ed.), Metallogeny Related to Tectonics of the Proterozoic Mobile Belts. Oxford and IBH Publishing, New Delhi, pp. 37-52.

Sorjonen-Ward, P., Ord, A., Kontonen, A., Alt-Epping, P., Zhang, Y., Kuronen, U., 2004. Geological constraints and numerical simulations of the formation and deformation of the Outokumpu $\mathrm{Cu}-\mathrm{Co}-\mathrm{Ni}-\mathrm{Zn}-\mathrm{Au}$ deposits. In: Muhling, J., et al., (Eds.), Predictive Mineral Discovery under Cover. Extended Abstracts, SEG Meeting, 27 September-1 October 2004. Perth, Western Australia, Centre for Global Metallogeny, The University of Western Australia. Publication, vol. 33, pp. 285-288.

Stein, M., Hofmann, A.W., 1994. Mantle plumes and episodic crustal growth. Nature 372, 63-68.

Stein, H., Morgan, J.W., Markey, R.J., Wiszniewska, J., 1998. A Re-Os study of the Suwalki anorthosite massif. Geophysical Journal 4, 111-114.

Sundblad, K., 1994. A genetic reinterpretation of the Falun and Åmmeberg ore types, Bergslagen, Sweden. Mineralium Deposita $29,170-179$.

Sundblad, K., 2003. Metallogeny of gold in the Precambrian of northern Europe. Economic Geology 98, 1271-1290.

Svetov, S.A., 2001. Archean high-MgO volcanism in east Fennoscandia. In: Cassidy, K.F., Dunphy, J.M., van Kranendonk, M.J. (Eds.), Fourth International Archaean Symposium; Extended
Abstracts. Australian Geological Survey Organisation Record, pp. 199-201.

Syme, E.C., Bailes, A.H., Price, D.P., Ziehlke, D.V., 1982. Flin Flon volcanic belt: geology and ore deposits at Flin Flon and Snow Lake, Manitoba. Field Trip Guidebook, Geological Association of Canada-Mineralogical Association of Canada Joint Meeting, Winnipeg. $90 \mathrm{pp}$.

Thurston, P.C., Ayres, L.D., 2004. Archean and Proterozoic greenstone belts: setting and evolution. In: Eriksson, P.G., Altermann, W., Nelson, D.R., Mueller, W.U., Catuneanu, O. (Eds.), The Precambrian Earth: Tempos and Events. Elsevier Science B.V., Amsterdam, pp. 311-333.

Toplis, M., Corgne, A., 2002. An experimental study of element partitioning between magnetite, clinopyroxene and iron-bearing silicate liquids with particular emphasis on vanadium. Contributions to Mineralogy and Petrology 144, 22-37.

Tuisku, P., 1985. The origin of scapolite in the Central Lapland schist area, northern Finland, preliminary results. Bulletin, vol. 331. Geological Survey of Finland, pp. 159-173.

Vaasjoki, M., 2001. Three decades of U-Pb mineral analyses at the Geological Survey of Finland. Special Paper, vol. 33. Geological Survey of Finland, pp. 9-13.

Vaasjoki, M., Sorjonen-Ward, P., Lavikainen, S., 1993. U$\mathrm{Pb}$ age determinations and sulfide $\mathrm{Pb}-\mathrm{Pb}$ characteristics from the Late Archaean Hattu schist belt, Ilomantsi, eastern Finland. In: Nurmi, P., Sorjonen-Ward, P. (Eds.), Geological Development, Gold Mineralization and Exploration Methods in the Late Archaean Hattu Schist Belt, Ilomantsi, Eastern Finland. Special Paper, vol. 17. Geological Survey of Finland, pp. 103-131.

Vaasjoki, M., Taipale, K., Tuokko, I., 1999. Radiometric ages and other isotopic data bearing on the evolution of Archaean crust and ore in the Kuhmo-Suomussalmi area, eastern Finland. Bulletin, vol. 71. Geological Society of Finland, pp. 155-176.

Vander Auwera, J., Longhi, J., 1994. Experimental study of a jotunite (hypersthene monzodiorite): constraints on the parent magma composition and crystallization conditions $\left(P, T, f \mathrm{O}_{2}\right)$ of the Bjerkreim-Sokndal layered intrusion. Contributions to Mineralogy and Petrology 118, 60-78.

Vander Auwera, J., Longhi, J., Duchesne, J.C., 2003. Some results on the role of $P, T$, and $f \mathrm{O}_{2}$ on ilmenite composition. NGU Special Publication 9, 35-37.

Vanhanen, E., 2001. Geology, Mineralogy and Geochemistry of the $\mathrm{Fe}-\mathrm{Co}-\mathrm{Au}-(\mathrm{U})$ Deposits in the Paleoproterozoic Kuusamo Schist Belt, Northeastern Finland. Bulletin, vol. 399. Geological Survey of Finland. 229 pp.

Vivallo, W., Claesson, L.-Å., 1987. Intra-arc rifting and massive sulphide mineralization in an Early Proterozoic volcanic arc, Skellefte District, northern Sweden. In: Pharaoh, T.C., Beckinsale, R.D., Rickard, D. (Eds.), Geochemistry and Mineralization Of Proterozoic Volcanic Suites. Geological Society, London, Special Publications, vol. 33, pp. 69-79.

Vlaar, N.J., 1986. Archaean global dynamics. Geologie en Mijnbouw 65, 91-101.

Vuollo, J.I., 1994. Paleoproterozoic basic igneous events in eastern Fennoscandian Shield between $2.45 \mathrm{Ga}$ and $1.97 \mathrm{Ga}$, studied by means of dyke swarms and ophiolites in Finland. Acta Univer- 
sitatis Ouluensis, Series A, Scientiae Rerum Naturalium, A 250 (116 pp.).

Wager, L.R., Brown, G.M., 1968. Layered Igneous Rocks. Oliver and Boyd Ltd., London. 588 pp.

Walker, R.J., Morgan, J.W., Hanski, E.J., Smolkin, V.F., 1997. Re-Os systematics of Early Proterozoic ferropicrites, Pechenga Complex, northwestern Russia: evidence for ancient ${ }^{187}$ Os-enriched plumes. Geochimica et Cosmochimica Acta 61, 3145-3160.

Wanhainen, C., Broman, C., Martinsson, O., 2003. The Aitik $\mathrm{Cu}-$ $\mathrm{Au}-\mathrm{Ag}$ Deposit in Northern Sweden: a product of high salinity fluids. Mineralium Deposita 38, 715-726.

Ward, P., 1987. Early Proterozoic deposition and deformation at the Karelian craton margin in southeastern Finland. Precambrian Research 35, 71-93.

Wasström, A., 1993. The Knaften granitoids of Västerbotten County, northern Sweden. Sveriges Geologiska Undersökning C 823, 60-64.

Weihed, P., 2001. A review of Palaeoproterozoic intrusive hosted $\mathrm{Cu}-\mathrm{Au}-\mathrm{Fe}-$ oxide deposits in northern Sweden. Sveriges Geologiska Undersökning C 833, 4-32.

Weihed, P., Eilu, P., 2005. Fennoscandian Shield - proterozoic VMS deposits. Ore Geology Reviews (this volume).

Weihed, P., Bergman, J., Bergström, U., 1992. Metallogeny and tectonic evolution of the Early Proterozoic Skellefte District, northern Sweden. Precambrian Research 58, 143-167.

Weihed, P., Billström, K., Persson, P.-O., Bergman Weihed, J., 2002. Relationship between 1.90-1.85 Ga accretionary processes and $1.82-1.80$ Ga oblique subduction at the 3451 Karelian craton margin, Fennoscandian Shield. GFF 124, 3452 $163-180$.

Weihed, P., Bergman Weihed, J., Sorjonen-Ward, P., 2003. Structural evolution of the Björkdal gold deposit, Skellefte district, northern Sweden: implications for Early Proterozoic mesothermal gold in the late stage of the Svecofennian orogen. Economic Geology 98, 1291-1309.

Williams, P.J., Guoyi, D., Pollard, P.J., Broman, C., Martinsson, O., Wanhainen, C., Mark, G., Ryan, C.G., Mernagh, T.P., 2003. The nature of iron oxide-copper-gold ore fluids. Fluid inclusion evidence from Norrbotten (Sweden) and the Cloncurry district (Australia). In: Eliopoulos, D.G., et al., (Eds.), Mineral Exploration and Sustainable Development. Millpress, Rotterdam, pp. $1127-1130$.

Wilson, J.R., Robins, B., Nielsen, F., Duchesne, J.C., Vander Auwera, J., 1996. The Bjerkreim-Sokndal layered intrusion, Southwest Norway. In: Cawthorn, R.G. (Ed.), Layered Intrusions. Elsevier Science B.V., Amsterdam, pp. 231-256.

Wiszniewska, J., Claesson, S., Stein, H.J., Vander Auwera, J., Duchesne, J.C., 2002. The north-eastern Polish anorthosite massifs: petrological, geochemical and isotopic evidence for a crustal derivation. Terra Nova 14, 451-460.

Yngström, S., Nord, A.G., Åberg, G., 1986. A sulphur and strontium isotope study of the Aitik copper ore, northern Sweden. Geologiska Föreningens i Stockholm Förhandlingar 108, 367-372. 